\title{
INFLUÊNCIA DA CONDUÇÃO DO PROCESSO DE FERMENTAÇÃO SOBRE A QUALIDADE E PRODUTIVIDADE DO HIDROMEL
}

\section{MARLA CRISTINA BARONE}

\author{
Orientador: Prof. Dr. JORGE HORII
}

Dissertação apresentada à Escola Superior de Agnicultura "Luiz de Queiroz", da Universidade de São Paulo, para obtenção do título de Mestre em Ciências, Área de Concentração: Ciência e Tecnologia de Alimentos.

P I R A C I C A B A

Estado de São Paulo - Brasil

Outubro - 1994 
Barone, Maria Cristina

B277i Influencia da conduça do processo de fermentaçzo sobre a qualidade e produtividade do hidromel.

Firacicaba, 1994.

156p. ilus.

Diss. (Hestre) - ESALQ

Eibliografia.

1. Hidromel - Tecnologia I. Escola Superior de Agri cultura Luix de Rueirox, Firacicaba

CDE 66:4 


\title{
INFLUÊNCIA DA CONDUÇ̃̃O DO PROCESSO DE FERMENTAÇÃO SOBRE A QUALIDADE E PRODUTIVIDADE DO HIDROMEL
}

\author{
MARIA CRISTINA BARONE
}

Aprovada em: 13/12/94

Comissão julgadora:

Prof. Dr. ${ }^{a}$ DJANIRA DE FRANCESCHI DE ANGELIS - UNESP/RIO CLARO

Prof. Dr. PAULO ROBERTO CANTARELLI - ESALQ/USP

Prof. Dr. JORGE HORII - ESALQ/USP

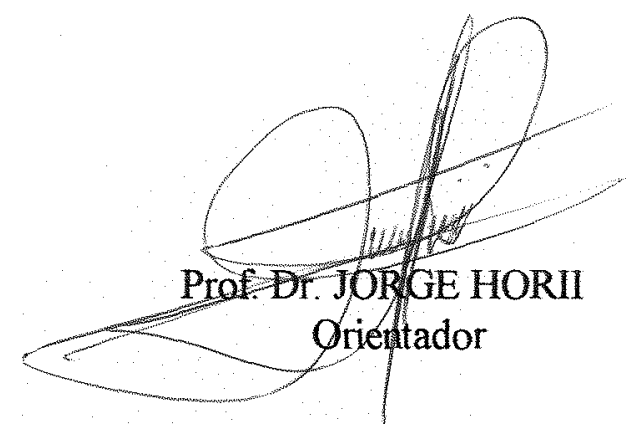


Aos meus pais, Mário e Neide

Ao meu marido, Pedro

\section{DEDICO}




\section{AGRADECIMENTOS}

- Ao Prof. Dr. Jorge Horii, por ter dado a oportunidade para a elaboração desse trabalho, pela orientação, amizade e apoio dispensados;

- À Escola Superior de Agricultura "Luiz de Queiroz", em especial ao Departamento de Ciência e Tecnologia Agroindustrial, pelos recursos oferecidos;

- A todos os Professores e Funcionários do Departamento de Ciência e Tecnologia Agroindustrial, em especial a Rosalina de Fátima Ocangne e Regina Helena Gonçalves;

- À Zelinda Aguiar Jordão pela amizade, incentivo e colaboração;

- Ao CNPq, pelo auxílio concedido em forma de bolsa de estudos;

- À Bibliotecária Beatriz Helena Giongo, pela atenção prestada à revisão bibliográfia;

- Aos colegas do Curso de Pós-Graduação pela convivência e incentivo;

- À todas as pessoas que, direta ou indiretamente, colaboraram para a realização desta pesquisa. 


\section{SUMÁRIO}

Pág.

LISTA DE FIGURAS v

LISTA DE TABELAS vii

RESUMO $\mathrm{X}$

SUMMARY xii 01

2. REVISÃO BIBLIOGRÁFICA 03

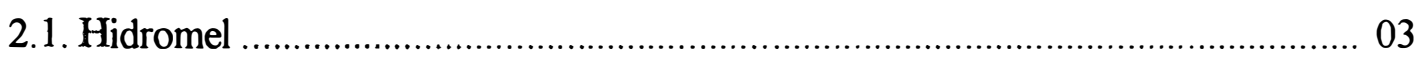

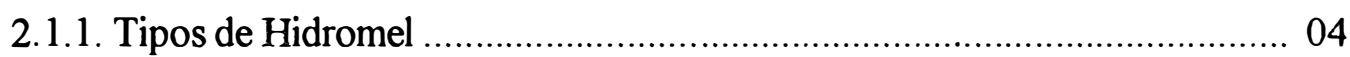

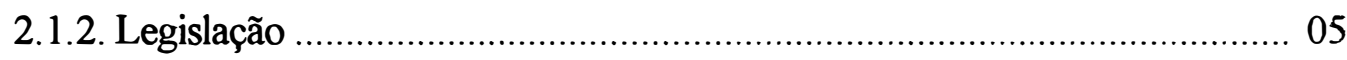

2.1.3. O mel como matéria-prima para fermentação …………………………... 06

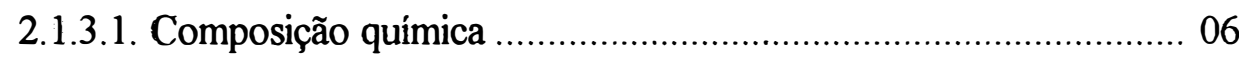

2.1.3.2. Processamento ....................................................................... 10

2.1.4. Composição química do hidromel ......................................................... 18

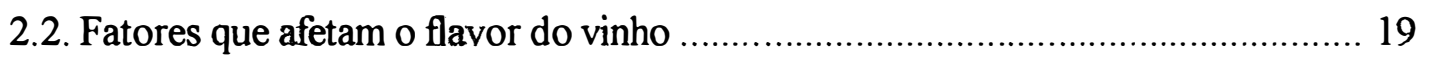

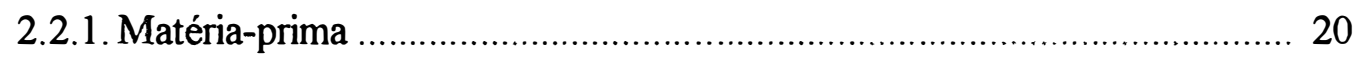

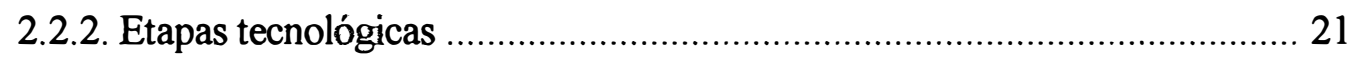

2.2.2.1. Linhagem e concentração de levedura ...................................... 21 
2.2.2.2. Temperatura

2.2.2.3. Sulfitação do mosto ........................................................... 26

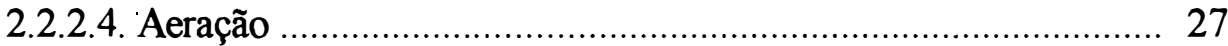

2.2.2.5. Fatores de crescimento ................................................... 28

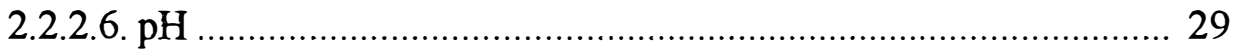

2.2.3. Substâncias formadas ou modificadas durante a fermentação por leve-

2.2.3.1. Ésteres ……................................................................. 30

2.2.3.2. Álcoois ........................................................................ 31

2.2.3.3. Ácidos orgânicos ........................................................... 32

2.2.3.4. Aldeídos e cetonas ........................................................ 33

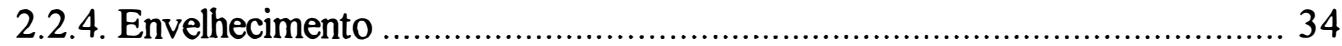

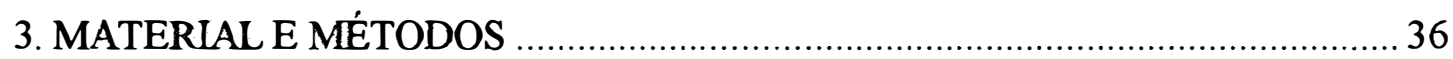

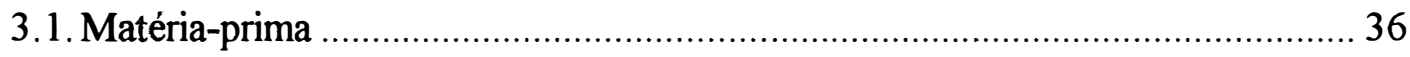

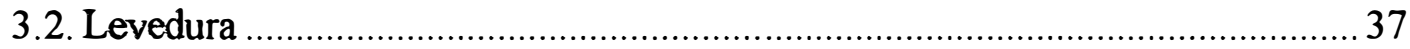

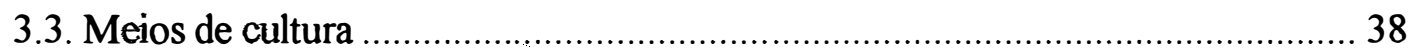

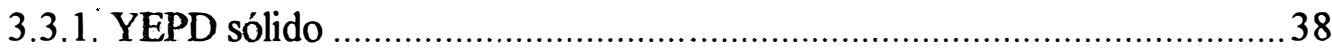

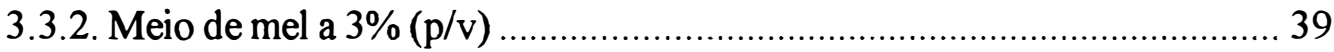

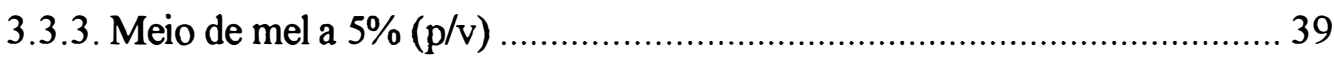

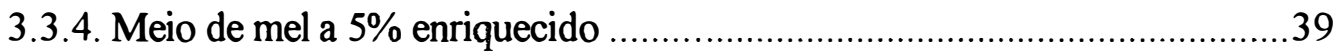

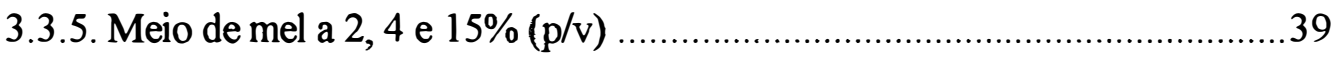

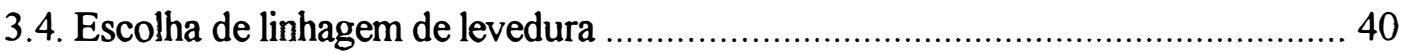


3.5. Isolamento de levedura a partir do fermento prensado

3.6. Multiplicação das leveduras .42

3.7. Preparo do mosto 43

3.7.1. Correção mineral 43

3.7.2. Adição de ácido cítrico 43

3.7.3. Tamponantes 43

3.8. Fermentadores 44

3.9. Processo de condução da fermentação 46

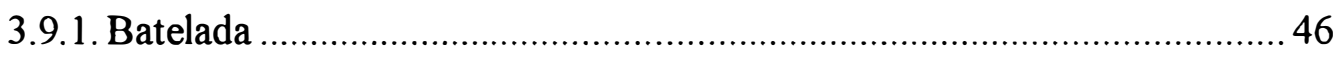

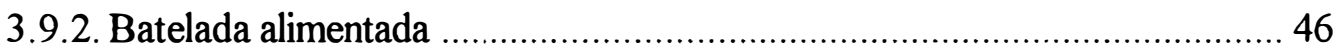

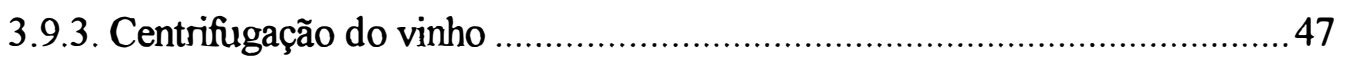

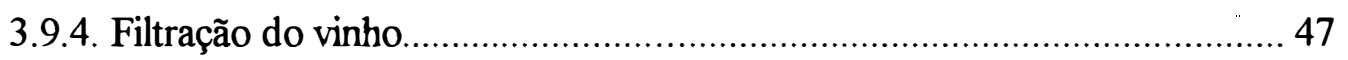

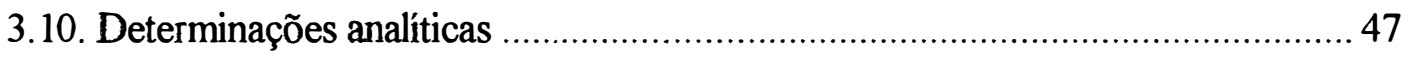

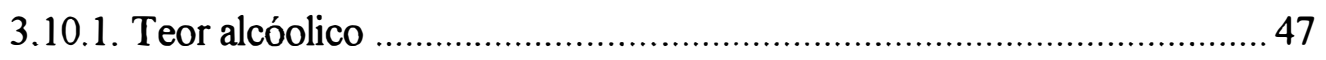

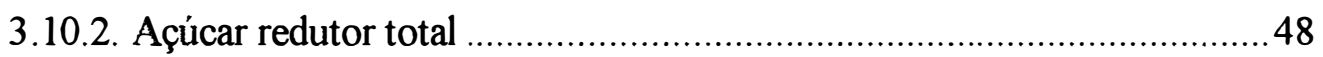

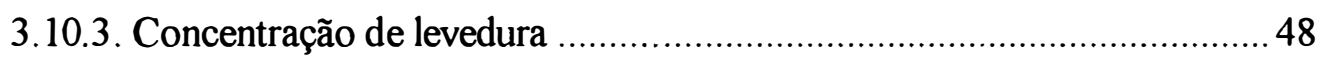

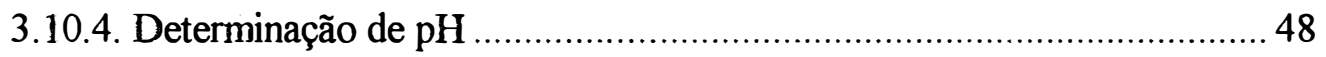

3.10.5. Acidez volátil e acidez total ..................................................... 48

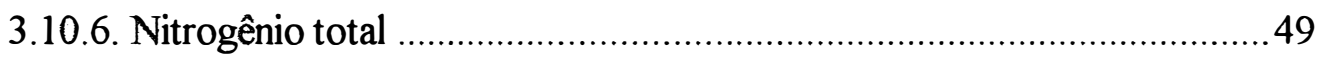

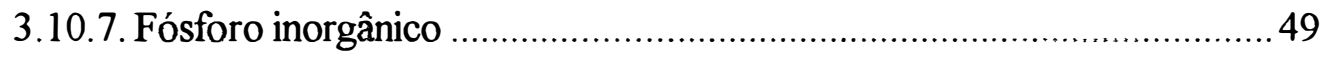

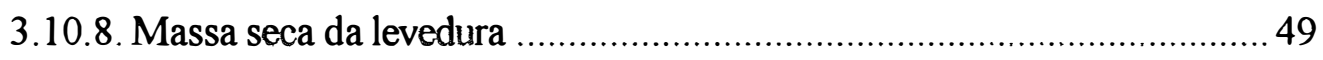

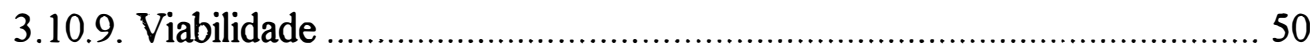

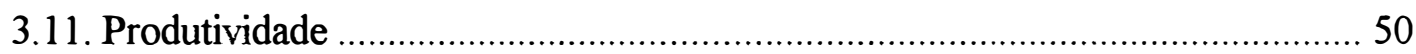


4.1. Composição química do mel

4.2. Linhagem de levedura 59

4.3. Fermentações conduzidas em batelada 59

4.3.1. Escolha da concentração celular inicial 62

4.3.1.1. Primeiro experimento em batelada 62

4.3.1.2. Segundo experimento em batelada 67

4.3.1.3. Terceiro experimento em batelada 72

4.3.1.4. Quarto experimento em batelada 77

4.3.1.5. Repetição do quarto experimento em batelada 83

4.3.2. Escolha do tamponante ou corretivo da acidez 89

4.3.2.1. Quinto experimento em batelada 90

4.3.2.2. Sexto experimento em batelada 97

4.3.2.3. Sétimo experimento em batelada 103

4.3.2.4. Oitavo experimento em batelada 109

4.4. Fermentações conduzidas em batelada alimentada

4.4.1. Batelada alimentada com agitação e correção de $\mathrm{pH}$ com solução de hidróxido de potássio

4.4.2. Batelada alimentada com agitação e correção de $\mathrm{pH}$ com sal de fosfato de potássio $\left(\mathrm{K}_{2} \mathrm{HPO}_{4}\right)$ 


\section{LISTA DE FIGURAS}

Pág.

Figura 1. Esquema da dorna de fermentação (em corte) e de seus acessórios

Figura 2. Açúcares redutores totais, massa celular, etanol e $\mathrm{pH}$ para $01^{\circ}$ experimento de fermentação em batelada

Figura 3. Ácidos totais (AT), ácidos voláteis (AV) e pH para o $1^{\circ}$ experimento de fermentação em batelada

Figura 4. Açúcares redutores totais, massa celular, etanol e $\mathrm{pH}$ para o $2^{\circ}$ experimento de fermentação em batelada

Figura 5. Ácidos totais (AT), ácidos voláteis (AV) e $\mathrm{pH}$ para o $2^{\circ}$ experimento de fermentação em batelada

Figura 6. Açúcares redutores totais, massa celular, etanol e $\mathrm{pH}$ para o $3^{\circ}$ experimento de fermentação em batelada

Figura 7. Ácidos totais (AT), ácidos voláteis (AV) e pH para o $3^{\circ}$ experimento de fermentação em batelada

Figura 8. Açúcares redutores totais, massa celular, etanol e $\mathrm{pH}$ para a $4^{\mathrm{a}}$ fermentação do $4^{\circ}$ experimento em batelada

Figura 9. Ácidos totais (AT), ácidos voláteis (AV) e pH para a $4^{\mathrm{a}}$ fermentação do $4^{\circ}$ experimento em batelada

Figura 10. Açúcares redutores totais, massa celular, etanol e $\mathrm{pH}$ para a $2^{\mathrm{a}}$ fermentação do $5^{\circ}$ experimento em batelada

Figura 11. Ácidos totais (AT), ácidos voláteis (AV) e pH para a $2^{\mathrm{a}}$ fermentação do $5^{\circ}$ experimento em batelada

Figura 12. Açúcares redutores totais, massa celular, etanol e $\mathrm{pH}$ para a $2^{\mathrm{a}}$ fermentação do $6^{\circ}$ experimento em batelada

Figura 13. Ácidos totais (AT), ácidos voláteis (AV) e pH para a $2^{\mathrm{a}}$ fermentação do $6^{\circ}$ experimento em batelada

Figura 14. Açúcares redutores totais, massa celular, etanol e $\mathrm{pH}$ para a $1^{\mathrm{a}}$ fermentação do $7^{\circ}$ experimento em batelada 
Figura 15. Ácidos totais (AT), ácidos voláteis (AV) e pH para a $1^{\text {a }}$ fermentação do $7^{\circ}$ experimento em batelada

Figura 16. Açúcares redutores totais, massa celular, etanol e pH para a $1^{a}$ fermentação do $8^{\circ}$ experimento em batelada

Figura 17. Ácidos totais (AT), ácidos voláteis (AV) e pH para a $1^{\mathrm{a}}$ fermentação do $8^{\circ}$ experimento em batelada

Figura 18. Açúcares redutores totais, massa celular, etanol e $\mathrm{pH}$ para a $3^{\mathrm{a}}$ fermentação do experimento em batelada alimentada

Figura 19. Ácidos totais (AT), ácidos voláteis (AV) e pH para a $3^{\mathrm{a}}$ fermentação do experimento em batelada alimentada

Figura 20. Açúcares redutores totais, massa celular, etanol e pH para a $4^{\mathrm{a}}$ fermentação do experimento em batelada alimentada

Figura 21. Ácidos totais (AT), ácidos voláteis (AV) e pH para a 4a fermentação do experimento em batelada alimentada

Figura 22. Açúcares redutores totais, massa celular, etanol e pH para a $9^{9}$ fermentação do experimento em batelada alimentada

Figura 23. Ácidos totais (AT), ácidos voláteis (AV) e pH para a $9^{\mathrm{a}}$ fermentação do experimento em batelada alimentada 


\section{LISTA DE TABELAS}

Tabela 1. Composição média (\%) dos constituintes do mel

Tabela 2. Elementos minerais do mel (p.p.m.)

Tabela 3. Resultados da fermentação alcóolica de sucos de abacaxi

Tabela 4. Nitrogênio encontrado em méis (p.p.m.) e algumas referências bibliográficas

Tabela 5. Fósforo encontrado em méis (p.p.m.) e algumas referências bibliográficas

Tabela 6. Resultados de concentração celular m.s. (g/l) e de açúcar residual $(\mathrm{g} / \mathrm{l}) \mathrm{em}$ meio de mel de "laranjeira" a 3\% em água destilada; a 5\% em água destilada e a $5 \%$ em água destilada acrescido de $1 \%$ de peptona e $1 \%$ de extrato de levedura

Tabela 7. Composição mineral de levedura comercial

Tabela 8. Resultados do $1^{\circ}$ experimento de fermentação em batelada com fermento prensado

Tabela 9. Resultados do $2^{\circ}$ experimento de fermentação em batelada com fermento prensado

Tabela 10. Resultados do $3^{\circ}$ experimento de fermentação em batelada com fermento prensado

Tabela 11. Resultados da $1^{\mathrm{a}}$ fermentação do $4^{\circ}$ experimento em batelada, pela linhagem de levedura isolada do fermento prensado

Tabela 12. Resultados da $2^{\mathrm{a}}$ fermentação do $4^{\circ}$ experimento em batelada, pela linhagem de levedura $S$. cerevisiae (IZ-888)

Tabela 13. Resultados da $3^{\mathrm{a}}$ fermentação do $4^{\circ}$ experimento em batelada, pela linhagem de levedura isolada do fermento prensado

Tabela 14. Resultados da $4^{\mathrm{a}}$ fermentação do $4^{\circ}$ experimento em batelada, pela linhagem de levedura $S$. cerevisiae (IZ-888). 
Tabela 15. Resultados da $1^{\text {a }}$ fermentação do $5^{\circ}$ experimento em batelada, com controle de $\mathrm{pH}$ com $\mathrm{KOH} 5 \mathrm{~N}$, pela linhagem de levedura isolada do fermento prensado

Tabela 16. Resultados da $2^{\mathrm{a}}$ fermentação do $5^{\circ}$ experimento em batelada, com controle de $\mathrm{pH}$ com $\mathrm{KOH} 5 \mathrm{~N}$, por S. cerevisiae (IZ-888)

Tabela 17. Resultados da $1^{\text {a }}$ fermentação do $6^{\circ}$ experimento em batelada, com controle de $\mathrm{pH}$ com $\mathrm{KOH} 5 \mathrm{~N}$, pela linhagem de levedura isolada do fermento prensado

Tabela 18. Resultados da $2^{\mathrm{a}}$ fermentação do $6^{\circ}$ experimento em batelada, com controle de $\mathrm{pH}$ com KOH $5 \mathrm{~N}$, por $S$. cerevisiae (IZ-888)

Tabela 19. Resultados da $1^{\mathrm{a}}$ fermentação do $7^{\circ}$ experimento em batelada, sem agitação, com controle de $\mathrm{pH}$ com $\mathrm{KOH} 5 \mathrm{~N}$, pela linhagem de levedura isolada do fermento prensado

Tabela 20. Resultados da $2^{\mathrm{a}}$ fermentação do $7^{\circ}$ experimento em batelada, sem agitação, com controle de $\mathrm{pH}$ com $\mathrm{KOH} 5 \mathrm{~N}$, pela linhagem de levedura isolada do fermento prensado

Tabela 21. Resultados da $1^{\mathrm{a}}$ fermentação do $8^{\circ}$ experimento em batelada, sem agitação e sem o uso de tamponantes, pela linhagem de levedura isolada do fermento prensado.

Tabela 22. Resultados da $2^{a}$ fermentação do $8^{\circ}$ experimento em batelada, sem agitação e sem o uso de tamponantes, pela linhagem de levedura isolada do fermento prensado

Tabela 23. Resultados da $1^{\text {a }}$ fermentação do experimento em batelada alimentada, com controle de $\mathrm{pH}$ com $\mathrm{KOH} 5 \mathrm{~N}$, pela linhagem de levedura isolada do fermento prensado

Tabela 24. Resultados da $2^{\mathrm{a}}$ fermentação do experimento em batelada alimentada, com controle de $\mathrm{pH}$ com $\mathrm{KOH} 5 \mathrm{~N}$, pela linhagem de levedura isolada do fermento prensado

Tabela 25. Resultados da $3^{\mathrm{a}}$ fermentação do experimento em batelada alimentada, com controle de $\mathrm{pH}$ com $\mathrm{KOH} 5 \mathrm{~N}$, pela linhagem de levedura isolada do fermento prensado

Tabela 26. Resultados da $4^{\mathrm{a}}$ fermentação do experimento em batelada alimentada, com controle de $\mathrm{pH}$ com $\mathrm{K}_{2} \mathrm{HPO}_{4}$, pela linhagem de levedura isolada do fermento prensado 
Tabela 27. Resultados da $5^{\mathrm{a}}$ fermentação do experimento em batelada alimentada, com controle de $\mathrm{pH}$ com $\mathrm{K}_{2} \mathrm{HPO}_{4}$, pela linhagem de levedura isolada do fermento prensado

Tabela 28. Resultados da $6^{\mathrm{a}}$ fermentação do experimento em batelada alimentada, com controle de $\mathrm{pH}$ com $\mathrm{K}_{2} \mathrm{HPO}_{4}$, pela linhagem de levedura isolada do fermento prensado

Tabela 29. Resultados da $7^{a}$ fermentação do experimento em batelada alimentada, com controle de $\mathrm{pH}$ com $\mathrm{K}_{2} \mathrm{HPO}_{4}$, pela linhagem de levedura isolada do fermento prensado

Tabela 30. Resultados da $8^{\mathrm{a}}$ fermentação do experimento em batelada alimentada, com controle de $\mathrm{pH}$ com $\mathrm{K}_{2} \mathrm{HPO}_{4}$, pela linhagem de levedura isolada do fermento prensado

Tabela 31. Resultados da $9^{a}$ fermentação do experimento em batelada alimentada, com controle de $\mathrm{pH}$ com $\mathrm{K}_{2} \mathrm{HPO}_{4}$, pela linhagem de levedura isolada do fermento prensado 
INFLUÊNCIA DA CONDUÇÃO DO PROCESSO DE FERMENTAÇÃO SOBRE A QUALIDADE E PRODUTIVIDADE DO HIDROMEL

Autor: MARIA CRISTINA BARONE

Orientador: JORGE HORII

\section{RESUMO}

O efeito de diferentes concentrações de inóculo, alimentação da dorna em batelada e batelada alimentada bem como condições físico-químicas, foram avaliados em relação à produtividade e aos padrões de identidade e qualidade da bebida, através de um estudo cinético.

Para a obtenção de hidromel seco com 10 a $11 \%$ de álcool (v/v), os mostos, 10 litros por experimento, foram preparados a partir de soluções de mel de laranjeira a aproximadamente $23 \%(\mathrm{p} / \mathrm{v})$. Para compensar o meio pobre em elementos minerais essenciais às leveduras, os mostos receberam aditivos nas seguintes concentrações: $1,587 \mathrm{~g} / 1$ de sulfato de amônio, $0,502 \mathrm{~g} / 1$ de fosfato de potássio e 0,185 g/l de cloreto de magnésio. Ácido cítrico foi utilizado para o ajuste de pH em torno de 3,8 para reduzir a possibilidade de contaminação bacteriana.

As fermentações foram conduzidas com fermento prensado comercial, S. cerevisiae (IZ-888) e uma linhagem isolada do fermento prensado, nas concentrações de 15,8 a $0,15 \mathrm{~g} / 1$ m.s.; a $24-26^{\circ} \mathrm{C}$; com e sem agitação; em batelada e 
batelada alimentada. A adição do mosto na batelada alimentada foi realizada em porções de $2.500 \mathrm{ml}$, adicionados a cada 24 horas.

Aproximadamente a cada 24 horas, foram realizadas análises das concentrações de etanol, levedura, açúcares redutores totais, acidez total e volátil; e foram verificados o $\mathrm{pH}$ e a temperatura. A filtração do vinho foi realizada com auxílio de CELITE 503.

A concentração do inóculo considerada satisfatória para ambos os processos foi de 0,20 a $0,30 \mathrm{~g} / 1$ de matéria seca, e a produtividade volumétrica encontrada foi por volta de $0,80 \mathrm{ml} \cdot \mathrm{l}^{-1} \cdot \mathrm{h}^{-1}$. $\mathrm{O}$ baixo poder tampão do meio de mel levou o $\mathrm{pH}$ em torno de 2,5, o qual afetou a viabilidade das leveduras. Por isso, houve a necessidade da adição de tamponantes, como o hidróxido de potássio e o fosfato dipotássico. A agitação de $100 \mathrm{rpm}$ proporcionou ganho de produtividade da ordem de $50 \%$ em relação ao processo estático.

Mostos preparados com solução de mel a $28 \%(\mathrm{p} / \mathrm{v})$, produziram vinhos com 10 a $11 \%$ álcool (v/v) e açúcar residual entre 25 a 45 g/l. Esses vinhos, produzidos nas mesmas condições que os secos foram mais apreciados.

Para o preparo de hidromel, seco ou doce, em 5 ou 6 dias, recomenda-se a correção mineral e a agitação do mosto bem como a correção do pH durante a fermentação. 
INFLUENCE OF FERMENTATION PROCESS CONDUCTION ON THE MEAD QUALITY AND PRODUCTIVITY

Author: MARIA CRISTINA BARONE

Adviser: JORGE HORII

\section{SUMMARY}

The effect of different concentrations of innoculum, batch feeding of fermenters, fed batches and physical-chemical conditions, were evaluated in relation to productivity and identity standards and beverage quality, by means of a kinetic study.

For the obtention of a dry mead having an alcohol content of 10 to $11 \%(\mathrm{v} / \mathrm{v})$, the musts, in lots of 10 liters per experiment, were prepared from solutions of orange honey at approximately $23 \%(\mathrm{w} / \mathrm{v})$. To compensate for the medium's poorness in minerals essential to the yeasts, the must received nutrients additives at the following concentrations: $15.87 \mathrm{~g} / 1$ ammonium sulphate, $0.502 \mathrm{~g} / 1$ potassium phosphate and 0.185 g/1 magnesium chloride. Citric acid was used to adjust $\mathrm{pH}$ to around 3.8 and to avoid bacterial contamination.

Fermentations were conducted with commercial pressed yeasts, $S$. cerevisiae (IZ-888) and a strain isolated from commercial pressed yeast, in concentrations of 15.8 to $0.15 \mathrm{~g} / 1$ of dry material; at $24-26 \mathrm{deg}$. C; with and without 
agitation; in batches and in fed batches. The addition of must to the fed batches was carried out in portions of $2,500 \mathrm{ml}$ added every 24 hours.

Approximately every 24 hours, analyses were carried out the concentrations of ethanol, yeast, total reducing sugars, total and volatile acidity; $\mathrm{pH}$ and temperature were checked. Wine filtration was carried out with the aid of CELITE 503.

An innoculum concentration considered satisfactory for both processes was 0.20 to $0.30 \mathrm{~g} / 1$ dry material and the volumetric productivity found was around $0.80 \mathrm{ml} \cdot \mathrm{l}^{-1} \cdot \mathrm{h}^{-1}$. The low buffering potential of the honey medium took the $\mathrm{pH}$ to around 2.5 , which affected the viability of the yeast. It was therefore necessary to add buffering agents such as potassium hydroxide and potassium hydrogen phosphate. Agitation at $100 \mathrm{rpm}$ produced a gain in productivity to the order of $50 \%$ in relation to the static process.

Musts prepared with honey solutions of $28 \%(w / v)$, produced wines with an alcohol content of 10 to $11 \%(\mathrm{v} / \mathrm{v})$ and residual sugar between 25 and $45 \mathrm{~g} / \mathrm{l}$. These wines, produced under the same conditions as the dry ones, were better appreciated.

For the preparation of dry or sweet mead in 5 or 6 days, it is recommended that mineral correction, the agitation of the must as well as $\mathrm{pH}$ correction during fermentation are carried out. 


\section{INTRODUÇÃO}

Muitas bebidas alcóolicas não destiladas, como cerveja e o vinho, já possuem um volume considerável de conhecimentos resultantes de pesquisas, das matérias-primas aos produtos, e que constituem as bases biotecnológicas de produção comercial.

Bebidas alcoólicas, com certeza, são produzidas em quase todos os países do mundo e representam uma fatia importante da economia desses países. Entretanto, dada a diversidade de produtos existentes, muitos deles não tem expressão econômica devido ao custo da matéria-prima, aos similares ou produtos competitivos de melhor aceitação ou popularidade. Neste grupo se encaixa o hidromel, que é o vinho de mel, não industrial, produzido empiricamente com utilização de culturas puras ou fermento prensado comercial de Saccharomyces cerevisiae e Saccharomyces uvarum, entre os nossos produtores e cujo produto tem mais caráter de "curiosidade" como vinho.

Ao contrário da Polônia, que tem até uma classificação de acordo com o volume de mel e água da diluição e composição do produto final em "póltorak", "dwójniak", "trójniak" e "czwórniak", respectivamente, diluições ou relação de mel e água, em volume de $2: 1 ; 1: 1 ; 1: 2$ e 1:3 (JARCZYC \& WZOREK, 1977), em nosso meio temos apenas uma legislação de padrão de qualidade em similaridade com outros 
produtos e receituário empírico. Assim, com o intuito de conhecer melhor a biotecnologia de produção de hidromel e, ao mesmo tempo, desenvolver um profissional para a condução de um processo tecnológico de produção de bebida alcóolica fermentada, foi proposto o presente tema e o estudo da matéria-prima, dos microrganismos da concentração de microrganismos e sua influência no flavor, dos meios de fermentação, da alteração de composição do meio, da acidez produzida e do $\mathrm{pH}$, da forma de condução do processo e dos tipos de vinhos obtidos. 


\section{REVISÃO BIBLIOGRÁFICA}

\subsection{Hidromel}

Hidromel - vinho de mel - vem sendo produzido e consumido por muitos anos. É uma das bebidas mais antigas do mundo (DENNIS, 1952; ADAM, 1953; WYNDHAM, 1965; TELLO, 1973; AQUARONE, 1983) e há na bibliografia um receituário extenso e empírico sobre métodos de produção.

O hidromel é mencionado na Bíblia e na mitologia grega, onde era considerado a bebida dos Deuses (WYNDHAM, 1965). Existem evidências que demonstram que o hidromel foi muito popular milhares de anos atrás e que foi produzido por pessoas de todas as civilizações incluindo egípcios, romanos e gregos. Na Inglaterra, entre 1000 e 1600 , o hidromel foi a bebida nacional. O metheglin, hidromel condimentado, por algum tempo também foi popular na Inglaterra. Na Polônia e partes de outros países eslavos e alemães o hidromel foi igualmente popular (MORSE, 1970).

Por volta de 1950, o vinho de mel era comercialmente produzido pelos E.U.A., Inglaterra, Costa Rica, França e Bélgica (MORSE, 1953a).

Segundo MORSE \& STEINKRAUS (1975), o declínio na produção do hidromel, nos séculos XVIII e XIX, provavelmente ocorreu devido à sua baixa qualidade 
pelo mal uso de leveduras que não possuiam suas funções bem compreendidas. Os autores relacionaram ainda a esse fato, o grande número de "receitas" antigas que acrescentavam condimentos e ervas, antes e após a fermentação, como sendo uma tentativa para disfarçar um produto deficiente.

No Brasil, o hidromel é de fabricação e consumo restrito e não apresenta a menor expressão econômica, dado ao caráter empírico com que é preparado por uma minoria de apicultores (SERZEDELLO, 1960). E assim permanece até o momento.

\subsubsection{Tipos de Hidromel}

O hidromel pode ser feito de quase toda variedade de mel, sendo que o vinho retém muitas das características do mel do qual é derivado. Méis claros produzem vinhos similares ao vinho branco como "Sauterne"; e méis escuros, de sabor forte, deveriam ser primariamente para a fabricação de "cerveja de mel". A média dos provadores americanos prefere hidromel feito a partir de mel claro a um de mel escuro (MORSE \& STEINKRAUS, 1975).

Pela variação da concentração de açúcar no mosto, podemos obter o hidromel seco, elaborado com mosto preparado com menos de $25 \%$ de açúcares totais; e o hidromel doce ou hidromel "sack", produzido a partir de mosto encerrando 25 a $35 \%$ de açúcares totais (SERZEDELLO, 1960). 
Além desses dois tipos, são conhecidos também: hidromel espumante, "metheglin", hidromel com sabor de frutas e outros. Segundo ADAM (1953), o hidromel espumante pode ser produzido engarrafando o vinho antes que a pósfermentação tenha começado. O mesmo autor define o "metheglin" como um hidromel condimentado, onde uma grande variedade de ervas são recomendadas em diferentes receitas. Gengibre, canela, alecrim, erva-doce, tomilho silvestre e muitos outros ingredientes são mencionados em várias receitas (MORSE, 1964).

Os termos usados para o hidromel com sabor de frutas variam de autor para autor, sendo os citados a seguir de maior uso comum: a) melomel, hidromel que inclui suco de frutas (com exceção de suco de uva e de maçã); b) pymeat, inclui o suco de uva; c) cysear, inclui o suco de maçãa (BERTHOLD JR., 1988).

O hidromel oferece um considerável potencial para a produção de destilados, conforme MORSE \& STEINKRAUS (1975), os quais retém somente uma alusão ao mel o qual foi originalmente fermentado.

\subsubsection{Legislação}

A legislação nacional estabelece, para o hidromel, graduação entre

$4^{\circ}$ G.L. e $14^{\circ}$ G.L. a $20^{\circ} \mathrm{C}$, obtida pela fermentação alcóolica de uma solução de mel de abelhas, sais minerais e água potável.

De acordo com a Portaria $N^{\circ} 410 / 74$, o hidromel deverá obedecer aos limites fixados a seguir: 


\begin{tabular}{lcc}
\hline & Máximo & Mínimo \\
\hline Alcool etilico em graus G.L. a $20^{\circ} \mathrm{C}$ & 14 & 4 \\
Acidez total em g/l & 9,75 & 3,75 \\
Acidez fixa em g/l & - & 2,25 \\
Acidez volátil em g/l & 1,2 & - \\
Extrato seco reduzido em g/l & - & - \\
Sulfatos totais em g/l & 1,00 & - \\
Anidrido sulfuroso total em g/l & 0,35 & - \\
Cloretos totais em g/l & 0,50 & 1,50 \\
Cinzas em g/l & - & - \\
\hline
\end{tabular}

Fonte: (BRASIL, s.d.)

A Portaria 371/74 do Ministério da Agricultura estabelece quais os aditivos a serem utilizados em bebidas e seus limites máximos de emprego. Nesta, o uso de hidróxidos $(\mathrm{Na}, \mathrm{Ca}, \mathrm{K})$ como tamponantes é omisso, embora sejam aceitos na legislação dos E.U.A. - Code of Federal Regulations - (MORAES, 1988).

\subsubsection{O mel como matéria-prima para fermentação}

\subsubsection{Composição química}

A Tabela 1 apresenta a composição média dos constituintes do mel, segundo White $\mathrm{Jr}^{1}$ et al., citado por WHITE JR. (1975).

${ }^{1}$ WHITE, JR., J.W.; RIETHOF, M.L.; SUBERS, M.H.; KUSHNIR, I. Composition of american honeys. Whashington, 1962. 124p. (TECHNICAL BULLETIN, 1261). 
Tabela 1. Composição média(\%) dos constituintes do mel.

\begin{tabular}{lrr}
\hline COMPONENTES & MÉDIA & \multicolumn{1}{c}{ VARIAÇÃO } \\
\hline Água & 17,20 & $13,40-22,90$ \\
Frutose & 38,20 & $27,20-44,30$ \\
Glicose & 31,30 & $22,00-40,70$ \\
Sacarose & 1,30 & $0,20-7,60$ \\
Maltose e outros & 7,30 & $2,70-16,00$ \\
dissac. redutores & 1,50 & $0,10-8,50$ \\
Açúcares superiores & 0,57 & $0,17-1,17$ \\
Acidos & 0,17 & $0,02-1,03$ \\
Minerais & 0,04 & $0,00-0,13$ \\
Nitrogênio & 3,91 & $3,42-6,10$ \\
pH & 310
\end{tabular}

FONTE: White Jr. et al., (1962)

Quanto aos elementos minerais, de acordo com AMARAL \& ALVES (1979), foram encontrados de 12 a 13 (potássio, cloro, enxofre, sódio, cálcio, fósforo, magnésio, sílica, ferro, manganês e cobre) regularmente presentes em diversos méis, sendo os méis escuros mais ricos em minerais que os méis claros, conforme se observa na Tabela 2.

Tabela 2. Elementos minerais do mel (p.p.m.).

\begin{tabular}{lcc}
\hline ELEMENTO MINERAL & $\begin{array}{c}\text { MÉDIA EM MEL } \\
\text { CLARO }\end{array}$ & $\begin{array}{c}\text { MÉDIA EM MEL } \\
\text { ESCURO }\end{array}$ \\
\hline Potássio & 205 & 1.676 \\
Cloro & 52 & 113 \\
Enxofre & 58 & 100 \\
Sódio & 18 & 76 \\
Cálcio & 49 & 51 \\
Fósforo & 35 & 47 \\
Magnésio & 19 & 35 \\
Silica & 9 & 14 \\
Ferro & 2,4 & 9,4 \\
Manganês & 0,3 & 4,1 \\
Cobre & 0,3 & 0,6
\end{tabular}

FONTE: WHITE JR. (1975). 
Chudakov $^{1}$ (1964), citado por STEINKRAUS et al. (1971), relatou a correlação entre o conteúdo de cinzas e o pH do mel. Ele deduziu a seguinte fórmula a partir de seus dados experimentais:

$$
y=0,47 x-1,49
$$

onde:y é a porcentagem do conteúdo de cinzas do mel e $\mathrm{x}$ é o pH.

Geralmente, o mel é ácido, e seu valor de $\mathrm{pH}$ varia entre 3,5 a 4,8. Contudo, a acidez do mel é muito encoberta por sua doçura. Os ácidos contribuem para o complexo flavor do mel (STEINKRAUS et al., 1971).

Existem muitos ácidos no mel, dentre os quais podemos citar: glicônico (em maior quantidade), cítrico, málico, succínico, fórmico, acético, lático, piroglutâmico e aminoácidos (AMARAL \& ALVES, 1979). Trompson² et al., citado por STEINKRAUS et al. (1971), relatou que a acidez do mel é devido primariamente ao ácido glicônico, o qual pode ser formado a partir da D-glicose por certas enzimas.

Segundo ainda AMARAL \& ALVES (1979), os méis contêm porções variáveis de algumas vitaminas. Em $100 \mathrm{~g}$ de mel, a vitamina $B_{1}$ varia de 2,1 a 9,1 (média 5,5) microgramas; a $\mathrm{B}_{2}$ de 25 a 145 (média 61,0) microgramas; a $\mathrm{B}_{6}$ de 210 a

${ }^{1}$ CHUDAKOV, V.V. Acid-base complex of domestic honeys. Trudy Nauchno-issledovalel'skogo Institute Pchelonestava, Mokna, $333-5,1964$.

${ }^{2}$ TROMPSON, A.; ANNO, K.; WOLFROM, M.L. \& INATOME, M. Acid reversion product from glucose. Journal American Chemistry Society, Washington, 76: 1309-11, 1954. 
480 (média 299) microgramas; o ácido ascórbico de 0,5 a 6,5 (média 2,4) miligramas e o ácido nicotínico de 0,4 a 0,94 (média 0,33) miligramas.

Há três enzimas importantes no mel: invertase, diástase (amilase) e glicose-oxidase, as quais desempenham papel na elaboração do mel da colméia e são sensíveis ao calor. Existe alguma invertase presente no mel acabado e, como resultado, a inversão da sacarose pode ocorrer ulteriormente, depois do mel ter sido extraído dos favos e durante a armazenagem. A glicose-oxidase é inativa em mel muito denso, mas torna-se ativa novamente em mel diluído, produzindo ácido glicônico e peróxido de hidrogênio (CRANE, 1983).

Um constituinte secundário do mel muito discutido é o hidroximetilfurfural (HMF). Esse composto resulta da quebra de açúcares hexoses na presença de um ácido. A quantidade de HMF certamente aumenta em méis submetidos a altas temperaturas, sendo que a cada $10^{\circ} \mathrm{C}$ extras aumentam a velocidade de produção de HMF cerca de 4,5 vezes (CRANE, 1983).

Segundo STEINKRAUS et al. (1971), os colóides presentes no mel foram originados de proteínas, partículas de cera, pentosanas e matéria inorgânica. Seu conteúdo varia de $1 \%$ nos méis escuros para $0,1 \%$ em méis claros.

ROSSI (1959)`realizou análises microbiológicas em duas amostras de mel (claro e escuro) da Etiópia, com o propósito de isolar as leveduras responsáveis pela sua fermentação natural. O estudo de 84 culturas isoladas apresentaram absoluta prevalência de Saccharomyces ellipsoideus, enquanto Saccharomyces mangini e Saccharomyces italicus foram encontradas com baixa freqüência; Hansenula anomala foi 
encontrada com particular abundância. O autor também obteve algumas leveduras esporogêneas pertencentes às espécies Candida krusei e Brettanomyces bruxellensis var. non membranaefaciens. Todas as culturas isoladas foram capazes de crescer em substrato com alta concentração de glicose e, entre elas, Hansenula anomala apresentou altíssima resistência. $\mathrm{O}$ autor concluiu que muitas das culturas obtidas podem ser vantajosamente usadas para a preparação de hidromel.

\subsubsection{Processamento}

De acordo com STEINKRAUS \& MORSE (1966), as fermentações na ausência de suficiente nitrogênio e fósforo são prolongadas. Insuficiência de vitaminas é menos grave, especialmente se o nitrogênio necessário está presente. A maior parte das leveduras possui a capacidade de sintetizar suas vitaminas necessárias, porém, se as vitaminas são fornecidas, o tempo de fermentação é reduzido.

Nota-se nos trabalhos sobre hidromel o reconhecimento de que o mel, quando diluído com água não é um produto satisfatório para a fermentação, daí a recomendação para se adicionar vários sais (MAUGENET, 1964; MORSE \& STEINKRAUS, 1975).

Quando o mosto de mel não recebe a adição de nutrientes minerais necessários à levedura a fermentação é longa, aproximadamente de 6 semanas, o que promove a autólise de leveduras que, muitas vezes, acompanhada de contaminação 
bacteriana, fornece ao vinho sabor desagradável (ADAMS \& NIESEN, 1963; MORSE \& STEINKRAUS, 1971; MORSE \& STEINKRAUS, 1975).

MORSE (1953b) recomenda a adição de 1,05 g/l de fosfato de amônio e a mesma quantidade de uréia ao mosto, sendo estes dispensados quando adicionado de suco de frutas. DENNIS (1952) também menciona o uso de sucos de frutas, os quais normalmente possuem proporções minerais adequadas para a correção do mosto de mel. BERGERET \& DE CASTRO (1943), obtiveram maior rapidez de fermentação, 25 dias, utilizando $200 \mathrm{mg} / 1$ de fosfato de amônio; MAUGENET (1964), aconselha a adição de $250 \mathrm{mg} / 1$ de fosfato de diamônio e $250 \mathrm{mg} / 1$ de bitartarato de potássio; STEINKRAUS \& MORSE (1966), concluíram que qualquer solução de mel corrigida com aditivos para as leveduras podem ser fermentados rapidamente (aproximadamente duas semanas), produzindo vinho de sabor agradável.

SERZEDELLO (1960); JARCZYK \& WZOREK (1977), relataram que qualquer mel, inclusive o de difícil comércio, pode ser utilizado para a produção de hidromel.

Segundo MAUGENET (1964), o mel empregado para a produção de hidromel deve possuir sabor "leve". Partículas de cera, própolis e fragmentos ou grãos de pólen, são elementos presentes no mel, que influenciam no aroma e freqüentemente causam sabores indesejáveis. Além disso, acrescentam fermentos lácteos ao mosto. Sendo assim, o autor recomenda a remoção desses materiais indesejáveis antes de proceder a fermentação. A filtração por meio de ś́lica é o método mais satisfatório. MAUGENET (1964) cita o tratamento tradicional pelo aquecimento, onde esses 
elementos ficam acumulados na espuma, à medida que ela se forma. Esse tratamento auxilia, ainda, a eliminação de microrganismos presentes no mel. Esta técnica apresenta como desvantagens o risco da produção de HMF e, além disso, ela não possibilita evitar uma dissolução parcial da cera e do própolis.

VIDAL (1983), efetuou vários testes onde produziu hidromel a partir de mosto de "mel de cana", contendo de 32 a 49,6\% de ART, e conduzindo as fermentações a temperaturas de 18 a $30^{\circ} \mathrm{C}$. O autor trabalhou com 23 leveduras, eficientes na produção de vinho de uva, e selecionou as mais apropriadas para o processo, considerando o rendimento alcóolico e a produtividade. Efetuou o acompanhamento das fermentações analisando os seguintes parâmetros: temperatura interna e externa, densidade, teor alcóolico e número de células no vinho.

VIDAL (1983) concluiu, com seu trabalho, que os mostos preparados a partir de "mel de cana" não requerem qualquer correção mineral e de pH para o estímulo da fermentação. Os vinhos, em início da fermentação, apresentaram pH em torno de 3,6 a 4,7 e os vinhos prontos, $\mathrm{pH}$ em torno de 3,0 a 4,0.

A produção de vinho é conduzida, geralmente, pela fermentação em batelada convencional, de acordo com ROSINI (1986), sendo que várias técnicas novas para fermentação tem sido propostas para atingir eficiência máxima na indústria de etanol, assim como, na produção de cerveja e outras bebidas alcóolicas. Sistemas contínuos não são empregados, porque requerem uma completa mudança do procedimento tradicional na produção de vinho. 
BORZANI (1987), concluiu que durante a fase de produção de etanol, quando da alimentação em batelada alimentada, a velocidade de formação de etanol foi constante, indicando a existência de uma correlação linear entre a variação da massa de etanol e o tempo, sendo a inclinação da reta função da alimentação e concentração do mosto.

Comparando os processos de batelada e batelada alimentada na fermentação por Saccharomyces cerevisiae (IZ 1904), ALMEIDA (1980) observou que as concentrações de açúcares na faixa de $270 \mathrm{~g} / 1$ inibiram a fermentação no processo de batelada convencional. $\mathrm{O}$ autor também relatou que a concentração do etanol de 25 $\mathrm{g} / 1$ determinou o término da fase exponencial de crescimento e de $80 \mathrm{~g} / 1$ apresentou inibição total. Concluiu também que batelada alimentada permite evitar o efeito inibidor do açúcar na fase exponencial.

Segundo HORII (1980), a maioria dos processos utilizados na prática em fermentação alcóolica são em batelada alimentada (exceção feita na fermentação contínua) e a alimentação é feita com a preocupação de se evitar a concentração excessiva de açúcares.

AQUARONE et al. (1986) realizaram fermentações de melaço, utilizando Saccharomyces cerevisiae e alimentação em batelada alimentada. Os autores observaram que as melhores produtividades foram obtidas com aumento do inóculo e com a alimentação do mosto realizada conforme o modelo decrescente.

A produção contínua de hidromel com células de Saccharomyces cerevisiae imobilizadas em alginato de cálcio foi realizada por QURESHI \& TAMHANE 
(1985). A produção de álcool foi estável em pH entre 2,5 e 6,0 e a temperatura entre 18 e $30^{\circ} \mathrm{C}$. O processo reduziu os problemas de contaminação e fermentação secundária associados com a produção tradicional de hidromel.

Quanto à melhor temperatura para a condução do processo, ADAM (1953) considera as que se encontram entre 20 e $22^{\circ} \mathrm{C}$; MAUGENET (1964), entre 20 e $25^{\circ} \mathrm{C}$; MORSE (1970) e BERTHOLD JR (1988) consideram as temperaturas entre $18^{\circ} \mathrm{C}$ e $21^{\circ} \mathrm{C}$; MORSE \& STEINKRAUS (1971) recomendam temperaturas entre $15 \mathrm{e}$ $18^{\circ} \mathrm{C}$; VIDAL (1983) considera as temperaturas em torno de 25 a $28^{\circ} \mathrm{C}$ ótimas para o metabolismo das leveduras.

MAUGENET (1964) relatou que a velocidade de fermentação possui, indiretamente, influência sobre o sabor. Segundo o autor, vinhos produzidos a $12^{\circ} \mathrm{C}$ apresentaram características gustativas mais finas que os produzidos a $25^{\circ} \mathrm{C}$. No entanto, ressalta que, do ponto de vista comercial, uma fermentação longa oferece pouca rentabilidade e oferece maiores riscos, além de que se pode afinar o gosto de vinhos pela prática do envelhecimento.

De acordo com MORSE (1964), poucas frutas contêm açúcar suficiente para produzir $10-12 \%$ de álcool. Já o mel é deficiente em ácidos e a maior parte das frutas os possuem em abundância. Sendo assim, a combinação de sucos de frutas e mel freqüentemente resulta em bons produtos.

MORSE (1953b) considera que vinhos de mel feitos com suco de frutas são, em média, melhores em sabor, corpo e aroma e que a quantidade de suco de frutas a ser usada varia com a fruta, sendo que, normalmente, a adição de 25 a $50 \%$ de suco 
por volume traz bons resultados. O autor recomenda o uso de sucos frescos para um melhor sabor. Os sucos com gosto forte, muito ácidos ou de cor muito escura, devem ser usados em pequenas quantidades.

STEINKRAUS \& MORSE (1966) produziram hidromel conduzindo as fermentações com dois níveis de pH $(2,9$ e 3,7$)$. Os autores concluíram que os diferentes níveis influenciaram consideravelmente a velocidade das fermentações, sendo que o pH a 3,7 foi suficiente para permitir uma rápida fermentação e ainda para inibir o crescimento indesejado de bactérias.

MAUGENET (1964) ressalta a importância de controlar a acidez e o poder tamponante no mosto, visto que pode ocorrer a diminuição da atividade das leveduras, devido à queda de $\mathrm{pH}$, até em torno de 2,5 , causada pelo insuficiente poder tampão do mosto de mel.

Para ajustar a acidez e obter um melhor sabor a adição de ácidos é recomendada. MORSE (1953b) indica a adição de 0,2 a 0,6\% de ácido málico, tartárico ou cítrico. MAUGENET (1964) recomenda a adição de 1,875 g/l de ácido tartárico ou $1,750 \mathrm{~g} / 1$ de ácido cítrico. $\mathrm{O}$ autor ressalta que, embora o ácido cítrico produza um melhor sabor o ácido tartárico é mais dificilmente metabolizado por bactérias do ácido lático.

A pasteurização do mosto é recomendada por ADAM (1953). BERTHOLD (1988) relatou ter encontrado mel com atividade enzimática que inibia o desenvolvimento da fermentação a menos que o mosto fosse antes fervido. 
ADAM (1953) aconselha a não utilização de qualquer produto químico no mosto, tanto para a correção do mosto quanto para evitar a contaminação bacteriana . Mas, MAUGENET (1964) faz fortes recomendações quanto ao uso de 25 a $50 \mathrm{mg} / 1 \mathrm{de}$ anidrido sulfuroso ou 50 a $100 \mathrm{mg} / 1$ de metabissulfito de potássio para prevenir o crescimento de bactérias láticas. VIDAL (1983) relatou que a esterilização do mosto pode ser feita pelo calor ou pelo emprego de metabissulfito de potássio na concentração de $0,3 \mathrm{~g} / 1$, embora tenha observado que o último tratamento limita um pouco o trabalho das leveduras e retarda a decantação dos vinhos.

A importância de se manter as células de leveduras em suspensão no mosto de mel, através de uma lenta agitação, foi enfatizada em patente de ADAMS \& NIESEN (1963). Os autores observaram que esta diminui o tempo de fermentação e reduz autólises de células.

Os vinhos de mel são mais difíceis de clarificar do que vinhos de frutas. Algumas pessoas deixam o hidromel no barril por um ou mais dias para que clarifique sozinho. Este procedimento geralmente não é recomendado, visto que as células de leveduras mortas podem afetar a qualidade do hidromel, se permanecerem em contato com o vinho por um certo tempo. Alguns produtores caseiros utilizam a clara do ovo com bons resultados, sendo que a clara de um ovo médio é suficiente para clarificar 3,8 litros (1 galão) de vinho. Tanino, gelatina e vários outros óxidos são também bons agentes clarificantes, mas requerem cuidados especiais para seu uso (MORSE, 1964). 
BERGERET \& DE CASTRO (1943) adicionaram no hidromel descubado, para sua clarificação, $0,1 \mathrm{~g} / 1$ de tanino, e o mantiveram à temperatura entre $18-20^{\circ} \mathrm{C}$ por quatro semanas. Após, permaneceu durante $48 \mathrm{~h}$ a $1^{\circ} \mathrm{C}$ em câmara fria para facilitar sua clarificação e, em seguida, foi filtrado.

O tempo reservado no processo de envelhecimento é, também, usado para o ajuste da composição química do hidromel. Para obter uma acidez total correta, adiciona-se ácido cítrico ou tartárico (MAUGENET, 1964). Para a produção de hidromel com alto conteúdo alcóolico adiciona-se destilados retificados. Embora aumente sua durabilidade, na Polônia, sua adição é permitida somente quando o álcool é elevado acima de $13 \%$ por volume. Para adoçar o vinho, adiciona-se mel diluído em água, através de processo frio ou quente. Adoçar com mel diluído a frio permite uma preservação maior do aroma, embora, ao mesmo tempo, cause na bebida uma adição de proteínas, as quais podem causar turbidez por precipitação de proteínas na forma de sedimentos. Somente mel com alta qualidade, com forte aroma, deve ser usado para adoçar (JARCZYK \& WZOREK, 1977).

A influência da substância nitrogenada em um fermentado de hidromel sobre as características de seu destilado alcóolico foi discutida por LESS (1943), o qual considerou importante que substâncias orgânicas nitrogenadas sejam eliminadas do líquido fermentado antes que este entre no alambique, para, sensivelmente, evitar a formação de aromas indesejáveis. 


\subsubsection{Composição química do hidromel}

MORSE (1972) elaborou 159 referências bibliográficas sobre vinhos de mel, mas poucas análises químicas referentes a esses vinhos foram relatadas. A composição química do hidromel é variada, porém, essa variação se mantém nos relatos dos autores, como pode ser observado a seguir.

STEINKRAUS \& MORSE (1973) analisaram 11 amostras de vinhos de mel comerciais e obtiveram os seguintes resultados: álcool de 12,2 a 20,8\% v/v; $\mathrm{pH}$ de 2,90 a 3,75; acidez total (ácido tartárico) 0,220 a $0,708 \mathrm{~g} / 100 \mathrm{ml}$; acidez volátil (ácido acético) 0,014 a $0,0779 \mathrm{~g} / 100 \mathrm{ml}$; açúcar residual (glicose) 2,5 a 27,8\%; acetaldeído 18,2 a 125,5 mg/1 (o conteúdo de acetaldeído nos dá uma idéia grosseira da quantidade de oxidação ocorrida durante o processo). O conteúdo de açúcar residual de 9 amostras analisadas foi de $10 \%$ ou mais, o que demonstrou que os hidroméis comerciais são razoavelmente doce. $\mathrm{O}$ conteúdo de cinzas variou de 0,0457 a $0,5201 \%$. Dentro dos limites de cinzas, o conteúdo de cálcio variou de 0,41 a $5,11 \%$, magnésio de 0,43 a 2,03\%, potássio de 8,62 a 74,19\% e sódio de 1,24 a 14,02\%. Esses resultados indicam os tipos de sais adicionados durante o processo.

Sarin $^{1}$, citado por STEINKRAUS \& MORSE (1973), analisou 42 vinhos de mel produzidos na Europa Oriental e relatou as seguintes variações: álcool de

\footnotetext{
${ }^{1}$ SARIN, E. Beiträge zur kenntnis der honigweine. Zeitschrift fur Untersuchung der Nahrungs-u. Genussmite 11, Berlim, 42: $90-8,1921$.
} 
6,4 a 16,6\% v/v; acidez total (ácido lático) de 0,342 a 1,062 g/100 ml; acidez volátil (ácido acético de 0,067 a 0,574 g/100 ml); açúcar residual de 0,71 a 37,44 g/100 ml; cinzas de 0,055 a $0,699 \mathrm{~g} / 100 \mathrm{ml}$.

Patschky \& Schone ${ }^{1}$, citados por STEINKRAUS \& MORSE (1973), analisaram 13 amostras de vinho de mel e obtiveram os seguintes dados: conteúdo alcóolico 6,6 a 14,2\% v/v; pH de 3,45 a 4,00; acidez total (ácido tartárico) 0,24 a 0,63 g/100ml; acidez volátil (ácido acético) 0,02 a 0,19 g/100ml.

BERGERET \& DE CASTRO (1943), produziram hidromel, em 25 dias, a partir de uma solução de $32 \%$ de mel adicionada de $120 \mathrm{mg} / 1$ de ácido tartárico e $200 \mathrm{mg} / \mathrm{l}$ de fosfato de amônio, a temperatura ambiente de 23 a $26^{\circ} \mathrm{C}$. Obtiveram, assim, um hidromel com a seguinte composição: álcool 12,19\% (v/v); acidez total 3,28 $\mathrm{g} / 1$; acidez volátil $0,15 \mathrm{~g} / 1$; açúcar residual $16,6 \mathrm{~g} / 1$; cinzas $0,82 \mathrm{~g} / 1$.

\subsection{Fatores que afetam o flavor do vinho}

AMERINE \& CRUESS (1960) designam como buquê o odor desenvolvido pelo vinho durante o envelhecimento, e, aroma, o odor derivado das frutas frescas. Os autores destacam, ainda, que existem odores não derivados da fruta ou do envelhecimento, como por exemplo, o do dióxido de enxofre e o do dióxido de

${ }^{1}$ PATSCHKY, V.A. \& SCHONE, H.J. Zur Zusammensetsung und Beurteilung von met. Deutsche Lebensmittel Rundschau, Stuttgart. 66(55): 150-7, 1970 . 
hidrogênio. Para os autores, o flavor é a impressão global do vinho, o que inclui seu buquê, aroma e gosto.

Segundo SCHREIER (1979), o flavor do vinho é essencialmente composto de:

1- Substâncias do flavor originadas da fruta.

2- Componentes dos quais são produzidos ou alterados devido a modificações causadas por etapas tecnológicas específicas;

3- Substâncias formadas ou modificadas durante a fermentação de leveduras;

4- Compostos originados durante o envelhecimento do vinho.

\subsubsection{Matéria-prima}

Dentro do grupo de mais de 100 compostos identificados do aroma, as mesmas substâncias principais aparecem na fração volátil de cerveja, vinho e bebidas destiladas. Sendo assim, parece evidente que a matéria-prima utilizada para a produção de bebidas contribui de maneira limitada, na composição do aroma. Os componentes do aroma mais notáveis sob o aspecto quantitativo são os produzidos pela levedura durante a fermentação. A natureza do aroma final depende, principalmente, do tipo de levedura usada, e das condições de fermentação (SUOMALAINEN, 1971). 


\subsubsection{Etapas tecnológicas}

Aqui são considerados os principais fatores que influenciam na formação de compostos pelas leveduras e que afetam o andamento da fermentação.

\subsubsection{Linhagem e concentração de levedura}

De acordo com KUNKEE \& AMERINE (1970), leveduras do vinho são aquelas que trabalham bem a acidez relativamente alta; que são freqüentemente resistentes à formação de mais de $10 \%$ de etanol; e que podem adaptar-se a baixas concentrações de $\mathrm{SO}_{2}$ adicionado como antissético. Foi estabelecido, a princípio, que o principal agente de fermentação alcoólica no vinho seria o Saccharomyces cerevisiae var. ellipsoideus (atualmente taxonomistas preferem classificar essa levedura simplesmente por Saccharomyces cerevisiae).

Há diferença sensorial entre os produtos formados por linhagens de Saccharomyces cerevisiae, bem como no comportamento das várias linhagens e na composição dos vinhos produzidos por elas. Há numerosos relatos sobre a influência das diferentes linhagens na formação de acidez fixa, ésteres, álcoois superiores, sulfito de hidrogênio, glicerol e 2,3-butileno-glicol (KUNKEE \& AMERINE, 1970).

KOSHIMIZU et al. (1982) encontraram a seguinte expressão para relacionar porcentagem em volume, e concentração em gramas de massa seca por litro: 


$$
\mathrm{X}=0,01+3,02 \mathrm{P}, \text { onde: }
$$

$\mathrm{X}=$ concentração de matéria seca $(\mathrm{g} / \mathrm{l})$

$\mathrm{P}=\%$ (em volume)

VIDAL (1983) selecionou leveduras, para a produção de hidromel, a partir de "mel de cana". O autor observou a variação na velocidade de fermentação entre as diferentes linhagens e a influência do teor alcóolico como fator limitante no metabolismo das leveduras, nas condições dos experimentos. O autor considerou 12, das 23 linhagens testadas, apropriadas para a produção de hidromel de boa qualidade, considerando a produtividade e o rendimento alcóolico.

ROSINI (1986) examinou o efeito de repetidas reutilizações de células na fermentação de mosto de uva sem casca (processo de fermentação em batelada com reciclo de células). Cultura pura de Saccharomyces cerevisiae foi inoculada em 10 litros de mosto, na concentração inicial de $0,32 \mathrm{~g} / 1$ de massa seca (ciclo 1). Foram realizados sete ciclos, onde a concentração celular aumentou progressivamente até o sétimo, e chegou a $28,40 \mathrm{~g} / 1 \mathrm{em}$ massa seca. Todas as fermentações foram conduzidas a $27^{\circ} \mathrm{C}$, sob leve agitação e tratadas com $200 \mathrm{mg} / 1$ de $\mathrm{SO}_{2}$.

As análises realizadas por ROSINI (1986), após o final da fermentação, não apresentaram diferenças detectáveis no conteúdo alcóolico e na acidez total, quando comparadas com vinhos produzidos pela fermentação tradicional (ciclo 1). Contudo, vinhos produzidos nos ciclos com maior concentração celular, apresentaram alta quantidade de acidez volátil, embora não houvesse contaminação bacteriana. Apesar disso, o autor recomenda esse processo para a produção de vinho de mesa e/ou de vinhos 
a serem destilados, em vista da redução da duração da fermentação e, consequientemente, do aumento da produtividade, podendo os custos serem consideravelmente reduzidos na elaboração desses produtos.

PONS et al. (1989) conduziram fermentações de suco de abacaxi a temperaturas entre 21 e $30^{\circ} \mathrm{C}$ e com três diferentes concentrações de inóculo: 3,$2 ; 6,5$ e 9,7 g/l de massa seca. Durante a fermentação, os componentes voláteis foram monitorados via um sensor de membrana de gás conectado para uma cromatografia a gás. A concentração de acetaldeído alcançou seu máximo quando a produção de etanol, álcoois superiores e $\mathrm{CO}_{2}$ foi máxima. Mais tarde, seu desaparecimento pode ter ocorrido devido ao reconsumo pelas leveduras. Os autores observaram que o aumento da temperatura ou da concentração de inóculo encurta o tempo de fermentação, sem modificar significativamente a concentração final de metabólitos. Os resultados podem ser observados na Tabela 3. 
Tabela 3. Resultados da fermentação alcoólica de sucos de abacaxi.

\begin{tabular}{|c|c|c|c|c|c|c|c|}
\hline & $\begin{array}{l}\text { Tempo de } \\
\text { Fermentação } \\
\text { (h) }\end{array}$ & \multicolumn{2}{|c|}{$\begin{array}{c}\text { Temperatura } \\
\left({ }^{\circ} \mathrm{C}\right)\end{array}$} & \multicolumn{2}{|c|}{$\begin{array}{l}\text { Inóculo } \\
\text { (g/l de } \\
\text { massa seca) }\end{array}$} & $\begin{array}{l}\text { Etanol } \\
(g / 1) \text { a }\end{array}$ & $\begin{array}{r}\text { Máximo } \\
\text { acetaldeí- } \\
\text { do(mg/l) }\end{array}$ \\
\hline 1 & 10,5 & & & & 6,5 & 74 & 28,6 \\
\hline 2 & 10,5 & & & & 6,5 & 59 & 43 \\
\hline 3 & 22 & & & & 6,5 & 55,6 & 51,3 \\
\hline 4 & 13,5 & & & & 6,5 & 42,8 & 35,7 \\
\hline 5 & 12 & & & & 6,5 & 54,6 & 52,6 \\
\hline 6 & 10 & & & & 9,7 & 54,8 & 35,6 \\
\hline \multirow[t]{2}{*}{7} & 16 & & & & 3,2 & 54,7 & 62,5 \\
\hline & $\begin{array}{l}\text { Acetato } \\
\text { de etila } \\
(\mathrm{mg} / \mathrm{l})\end{array}$ & $\begin{array}{l}\text { Propanol } \\
(\mathrm{mg} / \mathrm{l})\end{array}$ & $\begin{array}{r}\text { Isobu } \\
(\mathrm{mg}\end{array}$ & $\begin{array}{l}\text { anol } \\
1 \text { ) }\end{array}$ & $\begin{array}{c}\text { Álcool } \\
\text { isoamílico } \\
(\mathrm{mg} / \mathrm{l})\end{array}$ & $\begin{array}{r}\text { Total } \\
\text { sup }\end{array}$ & $\begin{array}{l}1 \text { Álcoois } \\
\text { periores } \\
\text { mg/l) }\end{array}$ \\
\hline 1 & 10 & 30 & & & 279 & & 429 \\
\hline 2 & 9,6 & 0 & & & 251 & & 387 \\
\hline 3 & 17 & 0 & & 4 & 281 & & 375 \\
\hline 4 & 9,6 & 0 & & & 230 & & 338 \\
\hline 5 & 9 & 0 & & & 256 & & 375 \\
\hline 6 & 11 & 0 & & & 256 & & 403 \\
\hline 7 & 10 & 0 & & & 294 & & 408 \\
\hline
\end{tabular}

Fonte: PONS et al. (1989)

\subsubsection{Temperatura}

ALMEIDA (1958) recomenda um aquecimento inicial do mosto em épocas frias e um sistema de refrigeração quando a temperatura estiver elevada. O autor ressalta que temperaturas entre 32 e $38^{\circ} \mathrm{C}$ são ótimas para um grande número de microrganismos prejudiciais à fermentação alcóolica, sendo, por isso, mais prejudiciais as altas temperaturas. 
PATO (1963) considera as temperaturas entre 20 e $25^{\circ} \mathrm{C}$ ótimas para as fermentações; entre 25 e $30^{\circ} \mathrm{C}$ ocorrem fermentações normais e as temperaturas acima de $33^{\circ} \mathrm{C}$ são perigosas. As fermentações conduzidas à temperatura abaixo de $20^{\circ} \mathrm{C}$ são lentas. As temperaturas acima de $33^{\circ} \mathrm{C}$, além de favorecerem o meio para a multiplicação de bactérias indesejáveis e poderem paralisar o trabalho das leveduras, facilitam o desprendimento tanto dos aromas, como do álcool que vai se formando.

OUGH \& AMERINE (1967) realizaram mais de 30 fermentações a temperaturas de 10,21 e $33^{\circ} \mathrm{C}$, usando Saccharomyces cerevisiae, e estudaram os compostos voláteis mais comuns e facilmente medidos para as três diferentes temperaturas de fermentação. As medidas de ácido acético e acidez volátil mostraram pouca alteração com a variação da temperatura, dados esses concordantes com trabalhos anteriormente publicados. Ésteres voláteis totais aumentaram à temperatura de $21^{\circ} \mathrm{C}, \mathrm{o}$ mesmo ocorrendo com acetaldeído, isoamil e álcoois amil ativo. Isobutanol não sofreu grande variação com a temperatura de fermentação. Etanol decresceu com o aumento da temperatura. Levo e meso 2,3-butanodiol aumentaram com o aumento da temperatura, assim como a acetoína.

Segundo NAGODAWITHANA et al. (1974), com o aumento de temperatura, o tempo de fermentação é reduzido e aumenta a velocidade de morte de células.

De acordo com STUPIELLO \& HORII (1981), a reprodução das células ocorrem até a temperatura de $38^{\circ} \mathrm{C}$, havendo a inibição de multiplicação a $40^{\circ} \mathrm{C}$. 
Segundo MARTINELLI FILHO (1982), o desenvolvimento do buquê e aroma é favorecido pela produção do vinho em baixas temperaturas, cerca de 21 a $24^{\circ} \mathrm{C}$. As leveduras do gênero Sacharomyces possuem um ótimo de temperatura correspondente a $25^{\circ} \mathrm{C}$, sendo o seu desenvolvimento extremamente favorável ao redor desse valor.

Sete cultivares de uvas brancas cultivadas em New York foram fermentadas a diversas temperaturas $\left(8,8^{\circ} \mathrm{C}-14,4^{\circ} \mathrm{C}-20,0^{\circ} \mathrm{C}-25,5^{\circ} \mathrm{C}\right)$, e observadas por COTTRELL \& MC LELLAN, (1986). Os autores não encontraram diferença marcante para dois cultivares. Entretanto, diferenças foram encontradas nos vinhos fermentados a temperaturas mais altas e mais baixas para 5 cultivares; estes, acredita-se, serem vinhos com maior natureza de frutas e flores. As análises químicas dos vinhos mostraram variações com a temperatura de fermentação e com o cultivar. Significantes aumentos nos componenetes fenólicos totais e no isobutanol e uma redução em acetato de etila foram observados com aumento da temperatura de fermentação, enquanto que os teores de metanol, propanol e amil acetato foram quase constantes.

\subsubsection{Sulfitação do mosto}

$\mathrm{O} \mathrm{SO}_{2}$ preenche várias funções na vinificação e suas propriedades bacteriostáticas evitam o desenvolvimento de organismos indesejáveis. Ainda, como um antioxidante ele protege o substrato do oxigênio atmosférico, inibe enzimas do mosto, 
ajuda na extração de pigmentos da casca e facilita a estabilização do mosto (HERRAIZ et al., 1989).

A propriedade antisséptica do $\mathrm{SO}_{2}$ é devido principalmente à forma livre. A taxa livre ou combinada disposta no vinho depedende da temperatura, da quantidade de açúcar e aldeído, e do pH (AMERINE \& CRUESS, 1960).

OUGH \& CROWELL (1987) estudaram dez sucos de uvas, normalmente usados para fabricação de vinhos, com o objetivo de determinar qual prétratamento do suco (com ar, cobertura do suco com nitrogênio ou pré-tratamento com $\mathrm{SO}_{2}$ ) seria o método mais satisfatório para produzir o melhor vinho. Cada mosto recebeu aproximadamente $1 \times 10_{6}$ células/ml de cultura de Saccharomyces cerevisiae, e as fermentações foram conduzidas a $15^{\circ} \mathrm{C}$. Concluíram que o $\mathrm{SO}_{2}$ foi essencial na produção do melhor vinho, apesar de fornecer aos vinhos pouca coloração. Vinhos sem $\mathrm{SO}_{2}$ foram geralmente menos apreciados. O pré-tratamento do suco com $\mathrm{SO}_{2}$ ajudou na preservação da qualidade, sendo provavelmente a da oxidação o controle mais importante exercido por ele.

\subsubsection{Aeração}

AMERINE \& CRUESS (1960) afirmam que a aeração, além de fornecer $\mathrm{O}_{2}$ para as leveduras, remove produtos da fermentação próximos da superfície das células e, além disso, favorece a substituição de novos nutrientes. 
A aeração durante a fermentação deve coincidir com um equilíbrio médio entre o excesso, que prejudica o rendimento em álcool, pela grande proliferação das leveduras, e a escassez, que a retarda em demasia, embora seja grande a produção de álcool. Os mostos aerados produzem vinho com buquê mais acentuado e que envelhecem mais rapidamente. Deve-se preferir a aeração contínua e lenta ao invés de uma brusca e intensa (MARTINELLI FILHO, 1982).

\subsubsection{Fatores de crescimento}

O nitrogênio é importante como estimulante da taxa de crescimento das leveduras. Mostos de mel são freqüentemente deficientes em nitrogênio e, por isso, uréia ou fosfato de amônio deve ser adicionado (MAUGENET, 1964; STEINKRAUS \& MORSE, 1966).

O curso normal da fermentação alcoólica, requer também magnésio, potássio, zinco, cobalto, iodo, ferro, cálcio, cobre e ânions de fósforo e enxofre (AMERINE \& CRUESS, 1960).

O magnésio e o fósforo são importantes para a nutrição da levedura, sendo o fósforo também indispensável para o funcionamento normal de seu sistema celular. O potássio é indispensável para o crescimento da levedura e o conhecimento de seu conteúdo é importante para prevenir a precipitação de tartarato ácido de potássio. A importância da determinação analítica de cobre e ferro no vinho relaciona-se com os 
limites legais e de prevenção de instabilidade de vinhos (DAUDT \& GARCIA, 1987; DAUDT et al., 1987).

Outras substâncias necessárias às leveduras são biotina, inositol, ácido nicotínico, ácido pantotênico, ácido p-aminobenzóico, piridoxina e tiamina. Muitos desses fatores de crescimento geralmente estão presentes em quantidades satisfatórias no mosto, além das leveduras poderem produzir alguns deles em quantidades suficientes (AMERINE \& CRUESS, 1960).

\subsection{6. $\mathrm{pH}$}

Segundo AMERINE \& CRUESS (1960), se o pH é muito baixo, 3,0 ou menos, a fermentação é relativamente reduzida.

PATO (1963) afirma que a acidez elevada, produzida por um $\mathrm{pH}$ baixo $(3,0$ a 3,6$)$, favorece a fermentação por se opor ao desenvolvimento das bactérias e pela seleção de leveduras.

2.2.3. Substâncias formadas ou modificadas durante a fermentação por leveduras

A composição do flavor do vinho é decisivamente influenciado durante o curso da produção do vinho pela fermentação de leveduras. Além dos compostos que dominam quantitativamente, como etanol e glicerol, isobutanol e isopentanol, surgem 
em menor quantidade substâncias como ésteres, cetonas, compostos contendo enxofre, e outros metabólicos, embora alguns ocorram somente em quantidades traços (SCHREIER, 1979).

\subsubsection{1. Ésteres}

Os ésteres encontrados nos vinhos provêm da combinação dos álcoois com os ácidos. Como nos vinhos existe um número variado de álcoois e ácidos, compreende-se que pela combinação desses, pode-se obter um número muito grande de ésteres (VALSECHI, 1960).

Os ésteres mais importantes encontrados no vinho são: acetato de etila, laurato de etila, propionato de etila, butanato de etila, acetato de amila, acetato de pentila e acetato de hexila (HASHIZUME, 1983).

Segundo AMERINE (1954), o acetato de etila predomina nos mostos fermentados, constituindo um éster importante sobre o ponto de vista de sabor e aroma.

RIBÉREAU-GAYON \& PEYNAUD (1961) analisaram a composição de vinhos de várias décadas e encontraram vinhos contendo, geralmente, entre 44 e 146 mg/1 de acetato de etila. Este, em baixas concentrações, é considerado como constituinte favorável ao aroma do vinho, mas, acima de $200 \mathrm{mg} / 1$, caracteriza um vinho deteriorado (AMERINE \& CRUESS, 1960). 
O acetato de etila é facilmente detectado por meios sensoriais, mas há pouco conhecimento do flavor e da importância dos outros ésteres como componentes do flavor do vinho (KUNKEE \& AMERINE, 1970).

\subsubsection{2. Álcoois}

Após o etanol, o glicerol é o constituinte do vinho mais importante, em volume, de 5 a $10 \mathrm{~g} / \mathrm{l}$. É um álcool com três funções álcoois. Seu sabor adocicado, contribui para a maciez do vinho, mas não constitui o fator principal. O glicerol é um produto da fermentação alcóolica. Seu teor no vinho depende do teor inicial de açúcar no mosto, bem como da espécie de levedura e das condições da fermentação (HASHIZUME, 1983).

De acordo com AMERINE \& CRUESS (1960), é geralmente aceito que metanol não é produzido pela fermentação, mas é derivado principalmente da hidrólise da pectina. Sendo assim, a produção de metanol é maior quando enzimas pectinolíticas são adicionadas ao mosto e quando o mosto é fermentado com casca.

Segundo KUNKEE \& AMERINE (1970), os principais álcoois superiores são n-propanol, isobutanol e álcoois isoamílico e amílico ativos. Eles possuem sabor e odor desagradáveis, mas estão usualmente, presentes em vinhos em concentrações tão baixas que não são necessariamente desfavoráveis e podem até contribuir para a sua qualidade. 
Segundo WEBB \& INGRAHAM (1963), a habilidade para a produção de álcoois superiores é aproximadamente a mesma para todas as linhagens de levedura de vinho, mas a habilidade em outras leveduras é altamente variável.

A aeração favorece a formação de álcoois superiores, e os tipos que serão formados são influenciados pelo substrato e pelo potencial redox (GUYMON et al., 1961).

\subsubsection{3. Ácidos orgânicos}

Os ácidos orgânicos encontrados no vinho em maior quantidade são: tartárico, málico, cítrico (provenientes da fruta), succínico, lático, acético (provenientes da fermentação). Os encontrados em pequenas quantidades são: galacturônico, glucurônico, glucônico, citromálico, dimetilglicérico, pirúvico, cetoglutárico, etc. (HASHIZUME, 1983).

Ácidos voláteis, principalmente ácido acético, são produzidos durante a fermentação, livre de bactérias, em quantidades consideráveis (MARGALITH \& SCHWARTZ, 1970). AMERINE \& CRUESS (1960), encontraram valores de 0,03 a $0,05 \%$ nos diferentes vinhos, e de zero a $0,02 \%$ nos mostos, respectivamente. $\mathrm{O}$ excesso de ácido acético, além de 0,05\% é uma indicação de deterioração bacteriana.

O teor do ácido succínico no vinho varia de 0,5 a $1,5 \mathrm{~g} / 1$. Apresenta um papel importante sobre o gosto. Seu sabor é uma mistura de gosto ácido, salgado e amargo (HASHIZUME, 1983). 
Dentre os ácidos orgânicos não voláteis produzidos durante a vinificação, o ácido lático ocupa a posição mais importante do ponto de vista prático e de interesse bioquímico. Esse ácido pode ter três origens: a) formação durante a fermentação alcóolica dos açúcares; b) mediante a fermentação malolática pelas bactérias láticas em função da transformação do ácido málico; c) nos vinhos alterados, sua formação se dá pela fermentação lática de açúcares, de glicerina, de ácido tartárico e de outros constituintes do vinho (HASHIZUME, 1983).

\subsubsection{Aldeŕdos e Cetonas}

Acetaldeŕdo é o principal componente do grupo aldeído, e é um subproduto normal da fermentação alcóolica (SCHREIER, 1979). Seu aparecimento pode ser explicado pela oxidação do álcool, pela influência do oxigênio do ar ou pela ação direta de algumas enzimas oxidantes oriundas da própria levedura (VALSECHI, 1960). Sendo assim, seu teor indica o grau de aeração a que foi submetido o vinho. Vinho branco com mais de $100 \mathrm{mg} / \mathrm{l}$ indica que foi arejado e oxidado (HASHIZUME, 1983).

As principais cetonas encontradas no vinho são: acetona, acetoína, diacetil e butilolactona. $\mathrm{O}$ teor de diacetil no vinho tinto pode ser superior a $3 \mathrm{mg} / \mathrm{l}$ mas, quando ultrapassa $4 \mathrm{mg} / 1$, torna-se indesejável. A acetoína é encontrada normalmente no vinho de 3,0 a 31,8 mg/l (HASHIZUME, 1983).

Do ponto de vista organoléptico, acetoína e seus produtos de redução 2,3-butileno-glicol, têm, aparentemente, pouca importância, embora o último deva ser 
considerado, uma vez que se oxidado formará o diacetil, que pode ser detectado a níveis muito baixos (MARGALITH \& SCHWARTZ, 1970).

\subsubsection{Envelhecimento}

Muitas alterações ocorrem durante o envelhecimento do vinho, e o processo químico envolvido está somente parcialmente compreendido. Vinhos novos possuem sabor de levedura, são freqüentemente turvos e possuem fraco buquê. Os vinhos de mel envelhecem mais rapidamente que vinho de frutas e o período de envelhecimento de um ano é usualmente suficiente. Como no caso da maioria dos vinhos, o envelhecimento em barris de carvalho é adequado (MORSE, 1964). O princípio de envelhecimento natural em barril é manter o vinho durante tempo suficiente, a fim de completar as diversas transformações que se sucedem após a fermentação principal: fermentação de açúcares ou ácidos, precipitações alcalinas ou coloidais (HASHIZUME, 1977).

A fermentação alcóolica de glicose e frutose residuais é favorecida pela aeração ocasionada pelas paredes da madeira. A permanência em barril de madeira não completa o processo de envelhecimento do vinho. Para completá-lo e atingir o máximo de seu valor organoléptico, ele deve permanecer por um período na garrafa (HASHIZUME, 1977).

Segundo RIBÉREAU-GAYON \& PEYNAUD (1961), na garrafa é que se processa o desenvolvimento do buquê, em condições reduzidas na ausência completa 
de oxigênio e quando o potencial de oxido-redução atinge um nível suficientemente baixo. Por outro lado, o buquê desaparece rapidamente ou se modifica profundamente quando o vinho é ligeiramente aerado, por essa razão, o vinho envelhecido na garrafa não deve ser decantado previamente antes do consumo. Dessa forma, admite-se que o buquê é devido às substâncias oxidáveis que apresentam odor agradável na sua forma reduzida. 


\section{MATERIAL E MÉTODOS}

Os experimentos foram conduzidos no laboratório de Açúcar e Álcool do Departamento de Ciência e Tecnologia Agroindustrial da Escola Superior de Agricultura "Luiz de Queiroz" da Universidade de São Paulo.

\subsection{Matéria-prima}

Para a preparação do mosto, foi utilizado mel de abelhas adquirido no comércio local. Mel de "laranjeiras" foi a matéria prima escolhida em função da facilidade de ser encontrado durante todo o ano. Além disso, a literatura recomenda o uso de mel claro para a produção de vinho de melhor qualidade.

No mel foram determinados: a) a concentração de açúcares redutores totais; b) os teores de nitrogênio e fósforo; c) o $\mathrm{pH}$. 


\subsection{Levedura}

Foram utilizadas nos experimentos de fermentação a levedura Saccharomyces cerevisiae -fermento prensado comercial Fleishmann, e culturas puras das leveduras citadas a seguir, obtidas da Coleção de Cultura do Departamento de Ciência e Tecnologia Agroindustrial, ESALQ/USP, desenvolvidas em meio de malte.

IZ 795 - Saccharomyces cerevisiae (H. St. Alpestris)

IZ 1215 - Levedura de melaço

IZ 774 - Levedura de Saké (Kamozuru)

IZ 671 - Saccharomyces cerevisiae

IZ 725 - Saccharomyces cerevisiae

IZ 194 - Saccharomyces cerevisiae

IZ 705 - Saccharomyces cerevisiae

IZ 669 - Saccharomyces cerevisiae

IZ 731 - Saccharomyces cerevisiae

IZ 880 - Saccharomyces cerevisiae (Dézaley)

IZ 881 - Saccharomyces cerevisiae (Fendant Sion)

IZ 862 - Saccharomyces cerevisiae (St. II Henneberg)

IZ 233 - Saccharomyces uvarum

IZ 866 - Saccharomyces cerevisiae

IZ 207 - Saccharomyces cerevisiae 
IZ 882 - Saccharomyces cerevisiae (Fendant Wadenswil)

IZ 863 - Saccharomyces cerevisiae

IZ 879 - Saccharomyces cerevisiae (Châtelaine 55 Dôle)

IZ 878 - Saccharomyces cerevisiae (Chasselas Tessin)

IZ 1012 - Saccharomyces cerevisiae

IZ 888 - Saccharomyces cerevisiae (Sauternes)

\subsection{Meios de cultura}

\subsubsection{YEPD sólido}

Para o isolamento e conservação da levedura foi utilizado o meio YEPD com agar, com a seguinte composição:

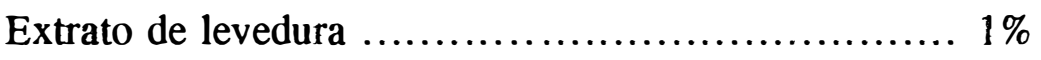

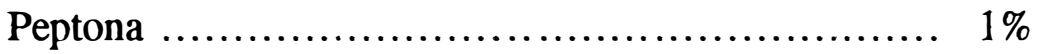

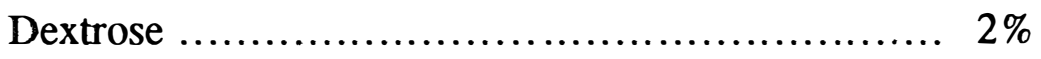

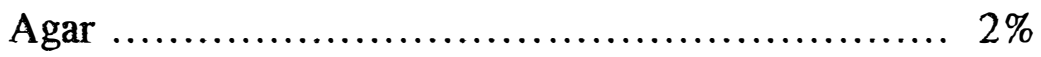

O meio foi dissolvido em água destilada sob aquecimento e autoclavado por 15 minutos a $121^{\circ} \mathrm{C}$. 


\subsubsection{Meio de mel a $3 \%(p / v)$}

Meio de mel a 3\% foi preparado diluindo-se 30g de mel de "laranjeira" em água destilada para completar um litro. $\mathrm{O}$ meio foi distribuído em erlenmeyer de $125 \mathrm{ml}$, os quais receberam $50 \mathrm{ml}$ de meio cada um. Para esterilização, o meio foi autoclavado por 15 minutos a $121^{\circ} \mathrm{C}$.

\subsubsection{Meio de mel a $5 \%(p / v)$}

Meio de mel a $5 \%$ foi preparado diluindo-se $50 \mathrm{~g}$ de mel de "laranjeira" em água destilada para completar um litro. A disuribuição nos frascos e a esterilização foram feitas de acordo com o descrito no item anterior.

\subsubsection{Meio de mel a $5 \%$ enriquecido}

O meio foi preparado de acordo com o descrito no item anterior, porém, acrescido de $1 \%$ de peptona e $1 \%$ de extrato de levedura.

\subsubsection{Meio de mel a 2,4 e $15 \%(p / v)$}

Para o preparo dos meios de mel a 2, 4 e $15 \%$, foram diluídos em becker separados, respectivamente, 20, 40 e $150 \mathrm{~g}$ de mel de "laranjeira" por litro de 
água destilada. Cada meio recebeu a adição de $1,5 \mathrm{~g} / 1$ de ácido cítrico Merck, p.a., para ajuste do pH e uma suplementação mineral nas seguintes concentrações:

$$
\begin{aligned}
& \left(\mathrm{NH}_{4}\right)_{2} \mathrm{SO}_{4}: 1,587 \mathrm{~g} / 1 \\
& \mathrm{~K}_{2} \mathrm{HPO}_{4}: 0,502 \mathrm{~g} / 1 \\
& \mathrm{MgCl}_{2} \cdot 6 \mathrm{H}_{2} \mathrm{O}: 0,185 \mathrm{~g} / 1
\end{aligned}
$$

Os meios foram distribuídos em erlenmeyer e tubos de ensaios e autoclavados por 15 minutos a $121^{\circ} \mathrm{C}$.

\subsection{Escolha de linhagem de levedura}

Nesse ensaio, foram utilizadas as leveduras descritas no item 3.2., com exceção da Saccharomyces cerevisiae - IZ - 888, e do fermento prensado comercial Fleishmann.

Para a multiplicação das leveduras, cada uma foi inoculada em $50 \mathrm{ml}$ de meio de mel a $3 \%$. Após 24 horas em estufa a $32^{\circ} \mathrm{C}$, retirou-se alíquota de $1 \mathrm{ml} \mathrm{de}$ cada frasco, que foi inoculado em $50 \mathrm{ml}$ de meio de mel a $3 \%$, em $50 \mathrm{ml}$ de meio de mel a $5 \%$ e em $50 \mathrm{ml}$ de meio de mel a $5 \%$ acrescido de $1 \%$ de peptona e $1 \%$ de extrato de levedura. O preparo desses meios está descrito no item 3.3.

Após 48 horas em estufa a $32^{\circ} \mathrm{C}$, foram realizadas análises para a determinação das concentrações de açúcar residual e da massa celular. 


\subsection{Isolamento de levedura a partir do fermento prensado}

Culturas puras de levedura, isolada do fermento prensado comercial Fleishmann, foram utilizadas do quarto experimento em diante.

Obtiveram-se os isolados a partir de uma suspensão do fermento prensado, de onde foram retiradas alíquotas de $0,1 \mathrm{ml}$, as quais foram inoculadas em placa de Petri contendo meio YEPD. As placas permaneceram em estufa de cultura por 48 horas a $32^{\circ} \mathrm{C}$.

Foram selecionadas colônias pela frequência e semelhança, as quais foram suspensas em água estéril e novamente inoculadas em placas de Petri, seguindo e repetindo os procedimentos anteriores até a obtenção das culturas puras. As colônias isoladas foram transferidas, com o auxílio de uma alça de Henle, para tubos de ensaio, contendo meio YEPD inclinado, os quais foram incubados por 48 horas a $32^{\circ} \mathrm{C}$.

A cada 30 dias, aproximadamente, eram realizadas repicagens em tubos para a manutenção da cultura, as quais, após crescimento em estufa a $32^{\circ} \mathrm{C}$, eram conservadas sob refrigeração. Antes do uso em experimentos de produção foram testadas quanto a silimaridade de produção de células e etanol, em meio YEPD e de mel a 5\% enriquecido. 


\subsection{Multiplicação das leveduras}

As leveduras IZ - 888 e a isolada do fermento prensado comercial foram multiplicadas conforme descrito a seguir.

A multiplicação de cada linhagem de levedura foi iniciada com dois frascos erlenmeyer de $500 \mathrm{ml}$ de capacidade, contendo $50 \mathrm{ml}$ de meio de mel a $2 \%$. Cada frasco recebeu "uma alça Henle" de inóculo, e ambos ficaram sob agitação constante em agitador rotatório. Após 12 horas, aproximadamente, cada frasco recebeu $50 \mathrm{ml}$ de meio de mel a $4 \%$ e, depois de 12 horas, $100 \mathrm{ml}$ de meio de mel a $4 \%$. Esses procedimentos procuraram manter a concentração do substrato em torno de $2 \%$ o que, juntamente com a alta agitação, deram condições para a síntese de novas células. A cada período aproximado de 12 horas, os frascos recebiam soluções de meio de mel a $15 \%$ na quantidade necessária para manter o meio a cerca de $2 \%$ de mel. A multiplicação era mantida por sete dias, quando então era atingida a concentração celular desejada.

Para a multiplicação das leveduras utilizadas da oitava fermentação em diante, na terceira alimentação do meio, o pH foi ajustado em torno de 4,0 com o auxílio de $\mathrm{KOH} 5 \mathrm{~N}$. Com esse procedimento o processo foi reduzido para 2,5 dias.

Para a separação das leveduras do meio, para posterior inoculação do mosto, foi utilizada a centrifuga da marca International Refrigerated Centrifuge, modelo PR-2 a $900 \times \mathrm{g}$, por 15 minutos a temperatura de $0^{\circ} \mathrm{C}$. 


\subsection{Preparo do mosto}

\subsubsection{Correção mineral}

Para permitir o crescimento de levedura e a fermentação, o mel diluído de cada experimento recebeu uma suplementação de sais inorgânicos, em concentrações similares às utilizadas por MORSE \& STEINKRAUS (1971):

$$
\begin{aligned}
& \left(\mathrm{NH}_{4}\right)_{2} \mathrm{SO}_{4}: 1,587 \mathrm{~g} / 1 \\
& \mathrm{~K}_{2} \mathrm{HPO}_{4}: 0,502 \mathrm{~g} / 1 \\
& \mathrm{MgCl}_{2} \cdot 6 \mathrm{H}_{2} \mathrm{O}: 0,185 \mathrm{~g} / 1
\end{aligned}
$$

\subsubsection{Adição de ácido cítrico}

Para ajustar o pH do mosto para valores inferiores a 4,0, a fim de reduzir a atividade de possível contaminação bacteriana, foi acrescentado ácido cítrico, Merck p.a. As concentrações utilizadas são apresentadas nos resultados e discussão de cada experimento.

\subsubsection{Tamponantes}

Foram utilizados o ácido ćftrico e fosfato de potássio formando o tampão citrato/fosfato ou fosfato/fosfato, conforme citado em BACILA (1960). 


\subsection{Fermentadores}

Utilizou-se de um conjunto de fermentadores, projetados pelo Prof. Dr. Jorge Horii, construídos em aço inox, com volume útil de 15 litros cada. O controle de temperatura dos fermentadores foi feito com o auxilio de camisa interna e de um circulador de água, com capacidade de variação da temperatura, no interior dos fermentadores, de $-40^{\circ} \mathrm{C}$ a $60^{\circ} \mathrm{C}$.

A agitação, controlada em rpm, foi feita através de palheta metálica acionada por um motor elétrico.

Para evitar que resíduos caíssem no mosto, cada fermentador foi coberto com uma tampa acrílica com aberturas que permitiram a passagem do agitador e das mangueiras que auxiliaram no controle da temperatura. Essas aberturas permitiram também a saída do $\mathrm{CO}_{2}$ formado durante a fermentação.

Um esquema do fermentador e de seus acessórios pode ser observado na Figura 1. 


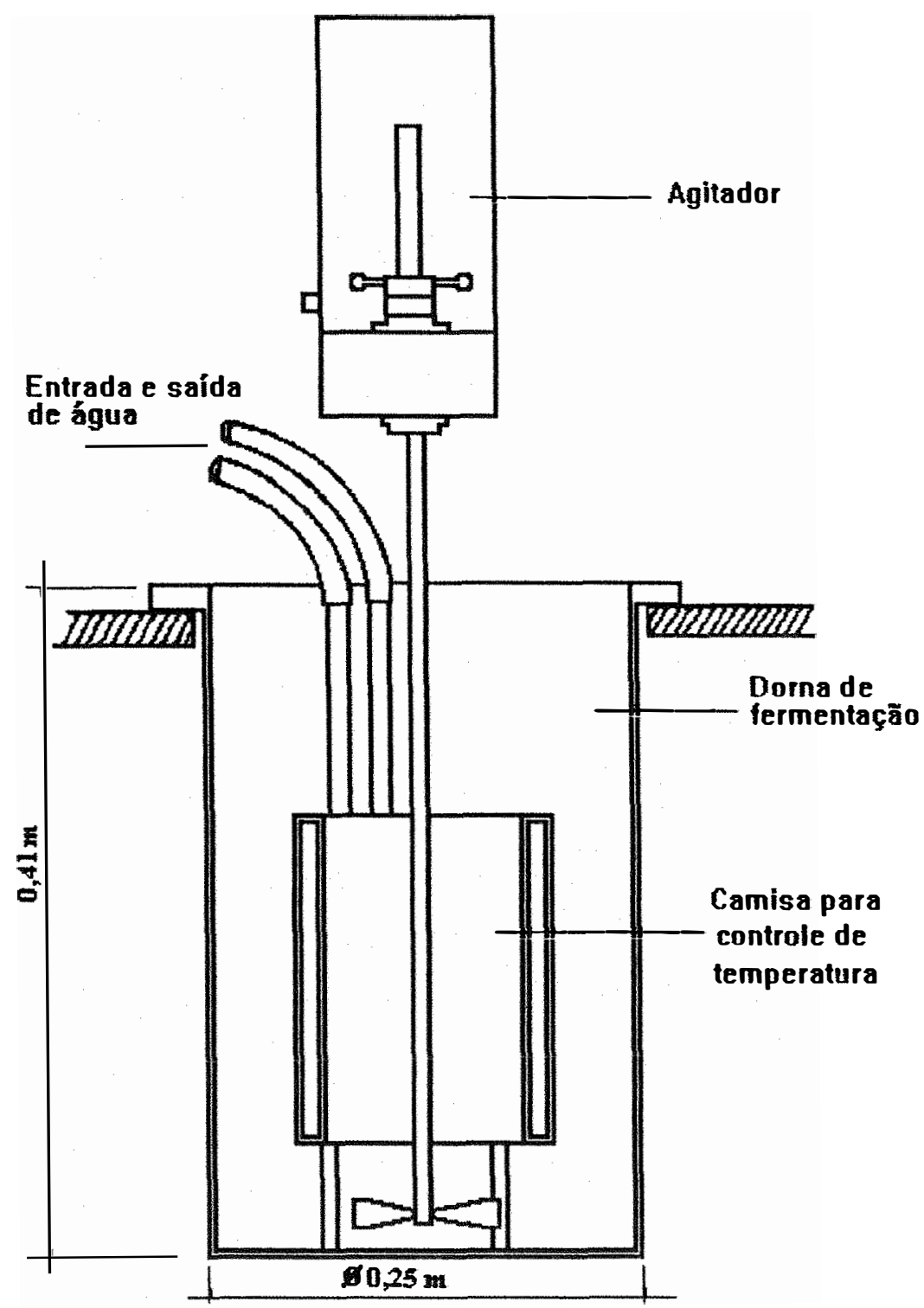

Figura 1. Esquema da dorna de fermentação (em corte) e de seus acessórios. 


\subsection{Processo de condução da fermentação}

\subsubsection{Batelada}

Nesse processo a solução de mel recebeu, de uma só vez, a adição dos sais minerais, do ácido cítrico e do inóculo. Após o volume foi completado para 10 litros com água destilada, obtendo-se assim, uma solução de mel de aproximadamente $23 \%$ $\mathrm{p} / \mathrm{v}$.

No início da fermentação ( 0 hora) retirou-se $45 \mathrm{ml}$ de amostra para determinação das concentrações de levedura, ART, acidez total e acidez volátil. Determinou-se também o pH e a temperatura, a qual foi mantida ao redor de $25^{\circ} \mathrm{C}$.

Foi retirada uma outra amostra, de $60 \mathrm{ml}$, nas cinco horas seguintes, e outras foram retiradas, aproximadamente, a cada 24 horas, para posteriores análises das concentrações de etanol, levedura, açúcar, acidez volátil e total. Verificou-se também o pH e a temperatura.

\subsubsection{Batelada alimentada}

Nesse caso, uma parte da solução de mel, já acrescida com os sais minerais e ácido cítrico, recebeu todo o inóculo. Após, seu volume foi completado para 2,5 litros com água destilada, obtendo-se uma solução de mel de aproximadamente $23 \%$ $\mathrm{p} / \mathrm{v}$, no caso de vinho seco, e de $28 \%$ p/v para vinho suave. 
A cada 24 horas o mosto foi alimentado com mais 2,5 litros de solução de mel a $23 \%$, sais minerais e o ácido cítrico em concentrações proporcionais ao volume, até atingir o volume de 10 litros na dorna.

A amostragem seguiu o descrito para a batelada convencional, onde as amostras foram retiradas imediatamente antes de cada alimentação.

\subsubsection{Centrifugação do vinho}

Para a centrifugação do vinho foi utilizado aparelho da marca International Refrigerated Centrifuge, modelo PR-2 a 900 x g, por 15 minutos a temperatura de $0^{\circ} \mathrm{C}$.

\subsubsection{Filtração do vinho}

O vinho centrifugado foi filtrado em funil com algodão e CELITE 503.

\subsection{Determinações analíticas}

\subsubsection{Teor alcóolico}

O grau alcóolico foi obtido por destilação de $25 \mathrm{ml}$ da amostra em microdestilador Tecnal modelo TE - 012 recolhendo-se $25 \mathrm{ml}$ do destilado em balão 
volumétrico e determinando-se a densidade relativa da solução em densímetro digital PAAR (DMA-45), transformando-se em grau alcóolico (v/v) por tabela apropriada.

\subsubsection{Açúcar redutor total}

A concentração de açúcar redutor total no mosto, assim como o teor de açúcar residual no vinho, foram analisados através de método espectrofotométrico SOMOGYI \& NELSON, segundo NEISH (1952).

\subsubsection{Concentração de levedura}

A concentração de levedura foi determinada por turbidimetria de acordo com TRIBOLI (1987).

3.10.4. Determinação de $\mathbf{p H}$

Determinado em pH-metro digital Metrohm Herisau, modelo E532.

\subsubsection{Acidez Volátil e Acidez Total}

A acidez volátil e a acidez total do mosto e vinho foram determinadas por titulação, segundo AMERINE \& OUGH (1974), usando $\mathrm{NaOH} 0,1 \mathrm{~N}$ para acidez 
total, e $\mathrm{NaOH} 0,01 \mathrm{~N}$ para acidez volátil, tendo a fenolftaleína como indicador. Para a análise da acidez volátil foi realizada previamente a separação dos ácidos voláteis por meio de destilação.

\subsubsection{Nitrogênio Total}

O teor de nitrogenio total presente no mel foi determinado pelo método de Micro-Kjeldahl, segundo VILELA; BACILA \& TASTALDI (1973).

\subsubsection{Fósforo inorgânico}

Para a análise de fósforo no mel foi utilizado o método colorimétrico de GOMORI (1942).

\subsubsection{Massa seca da levedura}

Determinou-se a massa seca de levedura através da diferença do peso úmido com o peso seco, obtido por secagem em forno microondas, na potência alta por 12 minutos, segundo SAKAI et al. (1990). 


\subsubsection{Viabilidade}

Determinou-se a porcentagem de células vivas, através de exame a fresco da suspensão de levedura coradas com solução de azul de metileno $0,01 \%$ e cirrato de sódio 2,0\%, de acordo com PIERCE (1970).

\subsection{Produtividade}

A produtividade foi expressa como concentração de etanol produzido na unidade de tempo $\left(\mathrm{ml} \cdot \mathrm{l}^{-1} \cdot \mathrm{h}^{-1}\right)$.

$$
P=\frac{\text { Etanol produzido }\left(\mathrm{ml} . \mathrm{h}^{-1}\right)}{\text { Volume útil da dorna }(\mathrm{l})}
$$




\section{RESULTADOS E DISCUSSÃO}

Antes de serem apresentados os resultados dos experimentos de produção de hidromel propriamente dito, vamos esclarecer alguns pontos da metodologia aplicada, citada no item anterior através de resultados de ensaios preliminares de análise química e de crescimento de leveduras.

\subsection{Composição química do mel}

Os dados constantes na literatura mostram que os méis, de uma maneira geral, apresentam uma enorme riqueza em açúcares, de cerca de $80 \%$, além de ácidos $(0,57 \%)$, proteínas $(0,26 \%)$, minerais $(0,17 \%)$, substâncias aromáticas, enzimas, dextrinas, vitaminas, e outros (WHITE JR., 1975).

Tais elementos são variáveis em concentração, permitindo inclusive que se classifique de modo empírico, quanto à riqueza em não açúcares, pela própria cor . Assim méis claros são mais pobres que méis escuros, ricos em constituintes minerais, ainda segundo WHITE JR. (1975).

Como no presente trabalho foi dada preferência ao uso de um único tipo de mel quanto a tonalidade e origem (mel claro e de laranjeira) foram feitas algumas 
análises dos principais componentes necessários à obtenção de massa celular de leveduras em fermentação no mel: $N$ e $P$, a saber.

Tabela 4. Nitrogênio encontrado em méis (p.p.m.) e algumas referências bibliográficas.

\begin{tabular}{lcccl}
\hline Mel & Min & Máx & Média & Referência \\
\hline Mel U.S.A. & 0 & 1.333 & 410 & WRITE JR.' et al., 1962 \\
$\begin{array}{l}\text { Laranjeira } \\
\begin{array}{l}\text { "Buckwheat" } \\
\text { (mel escuro) }\end{array}\end{array}$ & - & - & 140 & WRITE JR.' et al., 1962 \\
$\begin{array}{l}\text { "Clover" } \\
\text { (mel claro) }\end{array}$ & - & - & 640 & WRITE JR.' et al., 1962 \\
$\begin{array}{l}\text { Várias origens } \\
\text { Laranja }\end{array}$ & 400 & 1.020 & 640 & PIJANOWSHI ${ }^{2}$ et al., 1973 \\
Eucalipto & 263 & 207 & 131 & Presente trabalho \\
\hline
\end{tabular}

1 WRITE JR., J.W.; RIETHOF, M.L.; SUBERS, M.H.; KUSHNIR, I. Composition of american honeys, Washington, 1962. 124p. (TECHNICAL BULLETIN, 1261).

2 PIJANOWSHI, E.; MROZEWSKI, S. HORUBATA, A.; JARCZYK, A. Technologia Produktów Wocowych i Warzywnych, Warzawa, Pánstowowe Wydawnictwa Ro Inicze Lésne, 1973. v.1. 
Tabela 5. Fósforo encontrado em méis (p.p.m.) e algumas referências bibliográficas.

\begin{tabular}{|c|c|c|c|c|c|c|}
\hline \multicolumn{3}{|c|}{$\begin{array}{l}\text { Mel Claro } \\
\text { (p.p.m) }\end{array}$} & \multicolumn{3}{|c|}{$\begin{array}{c}\text { Mel escuro } \\
\text { (p.p.m) }\end{array}$} & \multirow[t]{2}{*}{ Referência } \\
\hline Min & Máx & Média & Min & Máx & Média & \\
\hline 48 & 89 & 68 & 59 & 80 & 69 & SUNDGREB \& LUNGREN ${ }^{1}, 1930$ \\
\hline- & - & - & 26 & 39 & 32 & JEWELL ${ }^{2}, 1931$ \\
\hline 23 & 50 & 35 & 27 & 58 & 47 & SCHUTTE \& HUENINK, 1937 \\
\hline- & - & 35 & - & - & 47 & WHITE, 1963 \\
\hline- & - & 56 & - & - & 54 & PETROV, 1970 \\
\hline 33 & 51 & 41 & 53 & 54 & 53,5 & Presente trabalho \\
\hline
\end{tabular}

As tabelas 4 e 5 mostram os resultados obtidos na análise de algumas amostras, comparadas aos dados da literatura colocados como referência.

A própria literatura básica de produção de hidromel traz referências a adição de certos sais, como o fosfato e o sulfato de amônio, de ácidos cítrico ou tartárico, que favorecem a fermentação tornando-a mais rápida e completa, fornecendo, portanto, "bebida seca" (SERZEDELLO, 1960). Na opinião ainda do mesmo autor, as melhores bebidas se conseguem com mostos exclusivamente de mel e água, sem qualquer

1 SUNDBERG, T. \& LUNDGREN, A. Untersuchung über die Aschenbestansteile in schwedischen honing. Archiv fur Beinenkunde, Leipzig, 11: 324-8, 1930.

2 JEWELL, W.R. Mineral constituints od some Victorian honeys. Journal of Departament of Agriculture Victoria, Meubourne, 29:435-6, 1931 . 
suplementação salina e com o emprego de uma boa levedura em ótimas condições de fermentação.

VIDAL (1983) seguindo possivelmente por essa linha de raciocínio, estudou uma série de linhagens de Saccharomyces cerevisiae quanto a capacidade de fermentar mel, tomando como parâmetro, a concentração de álcool alcançada após um período de tempo. Para seus ensaios, utilizou-se de méis de cana, tidos como méis de baixo valor comercial, porém do tipo escuro e de riqueza mineral geralmente mais elevada que os méis originários de flores de outras espécies vegetais, porém variáveis de partida para partida. Assim, as concentrações alcóolicas alcançadas por diferentes linhagens em diferentes meios serviram para classificar os melhores fermentadores.

No presente trabalho, apenas como um teste preliminar, tomou-se a maioria das linhagens estudadas por VIDAL (1983) e pertencentes a Micoteca do Departamento de Ciência e Tecnologia Agroindustrial da ESALQ, para um ensaio de crescimento de células em meio de mel de laranjeira a $3 \%$ em água destilada; a $5 \%$ em água destilada e a $5 \%$ em água destilada acrescido de $1 \%$ de peptona de $1 \%$ de extrato de levedura. Não se testaram outros tratamentos como dosagens de $\mathrm{N}$ e $\mathrm{P}$, para não transformar em um imenso fatorial que fugiria aos estudos da presente pesquisa.

Os resultados obtidos no referido ensaio estão mostrados na Tabela 6.

Observa-se que a concentração celular obtida em meios de mel diluidos exclusivamente em água na concentração de $3 \%$ ou $5 \%$ conduziram, após 48 h de cultivo, a uma média comum entre as 20 linhagens de cerca de $0,4 \mathrm{~g}$ de massa seca por litro 
contra uma média de $3,71 \mathrm{~g}$ de massa seca por litro quando se adicionou ao meio $1 \%$ de peptona e $1 \%$ de extrato de levedura.

Ficou assim evidente que houve uma restrição ou limitação ao crescimento, comum a todas as linhagens e que em função de tal, houve sensível queda na taxa de consumo, levando os microrganismos a consumir energia suficiente apenas para sua manutenção, justificando desse modo o açúcar residual médio entre as linhagens, de $18,43 \mathrm{~g} / 1$ no meio a $3 \%$, correspondendo a cerca de $79,78 \%$ do açúcar fornecido, após $48 \mathrm{~h}$ de cultivo. A mesma tendência foi observada no meio com $5 \%$ de mel apenas. Já no meio com $5 \%$ de mel suplementado com $1 \%$ de peptona e $1 \%$ de extrato de levedura o açúcar foi quase totalmente consumido e a massa celular seca resultante foi cerca de nove vezes maior. 
Tabela 6. Resultados de concentração celular m.s. $(\mathrm{g} / \mathrm{l})$ e de açúcar residual $(\mathrm{g} / \mathrm{l})$ em meio de mel de "laranjeira" a $3 \%$ em água destilada; a $5 \%$ em água destilada e a $5 \%$ em água destilada acrescido de $1 \%$ de peptona e $1 \%$ de extrato de levedura.

\begin{tabular}{|c|c|c|c|c|c|c|}
\hline \multirow[b]{2}{*}{ LEVEDURA } & \multicolumn{3}{|c|}{ Concentração celular m.s. (g/l) } & \multicolumn{3}{|c|}{ Açúcar residual $(\mathrm{g} / \mathrm{l})$} \\
\hline & $\begin{array}{l}\text { Solução de } \\
\text { Hel } 3 \%\end{array}$ & $\begin{array}{c}\text { Solução de } \\
\text { Mel } 5 \%\end{array}$ & $\begin{array}{l}\text { Solução de } \\
\text { Mel } 5 \% \text { com } \\
\text { nutrientes }\end{array}$ & $\begin{array}{l}\text { Solução de } \\
\text { Hel } 3 \frac{\text { a }}{}\end{array}$ & $\begin{array}{l}\text { Solução de } \\
\text { Hel 5\% }\end{array}$ & $\begin{array}{l}\text { Solução de } \\
\text { Hel } 5 \% \text { com } \\
\text { nutrientes }\end{array}$ \\
\hline IZ 795 & 0,39 & 0,38 & 3,33 & 17,75 & 32,31 & 1,25 \\
\hline IZ 1215 & 0,45 & 0,39 & 3,92 & 18,47 & 27,03 & 1,66 \\
\hline IZ 774 & 0,53 & 0,40 & 4,54 & 17,02 & 27,86 & 1,41 \\
\hline IZ 671 & 0,42 & 0,41 & 3,98 & 18,47 & 27,75 & 1,39 \\
\hline IZ 725 & 0,54 & 0,37 & 5,09 & 14,45 & 27,96 & 0,92 \\
\hline IZ 194 & 0,18 & 0,39 & 4,42 & 18,47 & 28,06 & 1,47 \\
\hline IZ 705 & 0,36 & 0,46 & 4,33 & 18,47 & 29,33 & 1,82 \\
\hline IZ 669 & 0,35 & 0,43 & 4,11 & 18,44 & 31,31 & 1,84 \\
\hline IZ 731 & 0,40 & 0,34 & 2,81 & 18,47 & 32,12 & 1,83 \\
\hline IZ 880 & 0,60 & 0,40 & 3,84 & 19,44 & 30,35 & 1,59 \\
\hline IZ 881 & 0,36 & 0,39 & 3,19 & 18,47 & 32,74 & 1,06 \\
\hline IZ 862 & 0,49 & 0,47 & 3,98 & 17,09 & 30,41 & 0,86 \\
\hline IZ 233 & 0,46 & 0,31 & 3,55 & 16,62 & 30,31 & 1,17 \\
\hline IZ 866 & 0,38 & 0,31 & 2,87 & 16,96 & 31,41 & 1,51 \\
\hline IZ 207 & 0,40 & 0,31 & 3,41 & 16,28 & 29,33 & 0,73 \\
\hline IZ 882 & 0,40 & 0,22 & 2,70 & 17,09 & 31,31 & 1,53 \\
\hline IZ 863 & 0,47 & 0,23 & 4,46 & 21,92 & 29,33 & 1,13 \\
\hline IZ 879 & 0,55 & 0,43 & 3,38 & 21,38 & 32,31 & 1,12 \\
\hline IZ 878 & 0,55 & 0,39 & 3,35 & 21,46 & 31,17 & 1,14 \\
\hline IZ 1012 & 0,52 & 0,44 & 2,90 & 21,84 & 32,21 & 0,94 \\
\hline MÉDIA & 0,44 & 0,37 & 3,71 & 18,43 & 30,23 & 1,32 \\
\hline
\end{tabular}

Aliás, tais resultados já eram esperados pois se a composição do mel concentrado demonstra baixo conteúdo em sais, o mesmo diluido terá sua concentração em sais identicamente diluído; daí a razão de complementação com sais quimicamente puros ou mesmo formulações incluíndo sucos de frutas, tais como: citros, abacaxi e outros com maior riqueza em sais.

O raciocínio da carência nutricional para bom desenvolvimento populacional das leveduras também poderia ser feito através da estequiometria do 
crescimento microbiano citados em HARRISON (1971), BAILEY \& OLLIS (1986), STOUTHAMER \& VAN VERSEVELD (1985) e outros.

Para HARRISON (1971), por exemplo, um balanço de reações globais em anaerobiose, em Saccharomyces cerevisiae aponta como sendo $\mathrm{C}_{6} \mathrm{H}_{10} \mathrm{O}_{5} \mathrm{~N}$, fórmula geral da massa celular, responsável por $91 \%$ do peso seco, sendo portanto $9 \%$ restantes representados por todos os sais encontrados nos microrganismos e apresentados na Tabela 7.

Como em anaerobiose o crescimento da massa celular é apenas cerca de $4 \%$ da massa celular obtida em aerobiose e segundo HARRISON (1971) esta é de $47,5 \mathrm{~g}$ por $100 \mathrm{~g}$ de glicose, a massa produzida seria então de $1,923 \mathrm{~g}$ por $100 \mathrm{~g}$ de glicose, sendo $0,173 \mathrm{~g}$ os sais necessários a cada $100 \mathrm{~g}$ de glicose consumida anaerobiamente.

Desta forma, foi adotada a suplementação do mosto com sais através modificação da fórmula da PATENTE US 3,598,607 (MORSE, 1971). 
Tabela 7. Composição mineral de levedura comercial.

\begin{tabular}{|c|c|c|}
\hline Elemento & $\begin{array}{r}\text { Levedura }(g \\
\text { m.s. }\end{array}$ & $\mathrm{g} / 100 \mathrm{~g})$ \\
\hline $\begin{array}{l}\mathrm{C} \\
\mathrm{H} \\
0 \\
\mathrm{~N} \\
\mathrm{~K} \\
\mathrm{P} \\
\mathrm{S} \\
\mathrm{Mg} \\
\mathrm{Ca} \\
\mathrm{Na} \\
\mathrm{Zn} \\
\mathrm{Fe} \\
\mathrm{Cu} \\
\mathrm{Mn} \\
\mathrm{Co} \\
\mathrm{Mo} \\
\mathrm{Cl} \\
\mathrm{I} \\
\mathrm{Pb} \\
\mathrm{As} \\
\mathrm{Si} \\
\mathrm{Sr} \\
\mathrm{B}\end{array}$ & $\begin{array}{l}45 \\
6,0 \\
31 \\
7,5 \\
0,9 \\
1,1 \\
0,3 \\
0,15 \\
0,04 \\
0,02 \\
0,004 \\
0,003 \\
0,002 \\
0,0004 \\
0,0005 \\
0,000005 \\
0,004 \\
0,00005 \\
0,0001 \\
0,00001\end{array}$ & $\begin{array}{l}-47 \\
-\quad 6,5 \\
-\quad 32 \\
-\quad 9,0 \\
-\quad 3,5 \\
-\quad 2,0 \\
-\quad 0,5 \\
-\quad 0,5 \\
-\quad 0,9 \\
-\quad 0,2 \\
-\quad 0,13 \\
-\quad 0,1 \\
-\quad 0,012 \\
-\quad 0,0035 \\
-\quad 0,000009 \\
-\quad 0,1 \\
-\quad 0,0004 \\
-\quad 0,0007 \\
-\end{array}$ \\
\hline
\end{tabular}

Fonte: HARRISON (1971)

Ao se proceder a adoção de tal técnica obviamente estávamos procurando obter também aumento de produtividade pelo mais rápido crescimento celular e consumo de açúcar, aumento do poder tamponante, procurando interferir o mínimo possível no aspecto organoléptico ou sensorial, apesar de não ter sido efetuada uma análise sensorial desejável, tanto pela falta de u ma bebida padrão no mercado como pela ausência de degustadores a serem treinados para tal fím. 


\subsection{Linhagem de levedura}

O grande número de linhagens utilizadas nos testes preliminares, para adoção de sais como suplemento nutricional às leveduras, não teve o intuito de seleção de linhagens nem para crescimento nem para sensorial ou organoléptico, buscou-se apenas mostrar que a restrição encontrada por VIDAL (1983) era mais de caráter nutricional e não de adaptação ou adequação da linhagem ao meio de mel.

Desse modo, trabalhamos inicialmente com fermento prensado comercial em três testes, em seguida com linhagem isolada de fermento comercial e a linhagem IZ-888, já tradicionalmente utilizada por produtores de hidromel, em nove testes e posteriormente apenas com a linhagem isolada do fermento prensado, uma vez que nenhum elemento auxiliar de degustação conseguiu detectar qualquer sensibilidade organoléptica entre linhagens.

Nesse aspecto, um verdadeiro trabalho de seleção de linhagens implicaria num profundo estudo de flavor e buquê analisados por inúmeras técnicas de caracterização de compostos químicos voláteis, aromáticos, e outros que não seria possível no presente trabalho.

\subsection{Fermentações conduzidas em batelada}

Tradicionalmente a produção de vinhos, dos quais o hidromel é um representante, tem sido descrito como produzido pelo processo convencional em 
batelada, ou seja, onde todo o mosto a fermentar é inoculado com todo o fermento e a fermentação é acompanhada até o seu ponto considerado final, seco, suave ou doce, conforme o açúcar residual que se queira restar ou mesmo adicionar.

A inoculação do mosto deve ser conduzida com um volume variável entre 3 a $10 \%$ do volume do mosto, segundo JARCZYK \& WZOREK (1977); 5 a $10 \%$ - VAN TOL FILHO (1964); 0,5\% em volume - MORSE \& STEINKRAUS (1971).

Note-se que os dados constantes na literatura são muito empíricos e expressam volumes percentuais sem definição de conteúdo ou concentração de massa seca ou úmida de células. Em JARCZYK \& WZOREK (1977) encontra-se uma citação de Hroncek \& Malik' como sendo um ótimo conteúdo de massa seca de levedura "starter" igual a 12,5 g/l ou ainda Wasilenshi ${ }^{2}$ afirmando ser necessário a adição de aproximadamente 100 milhões de células de leveduras por litro de mosto.

De acordo com Saller ${ }^{3}$, citado por KUNKEE \& AMERINE (1970), o efeito do volume e da concentração de inóculo na qualidade do vinho parece não ser ainda um assunto muito bem estudado. Óbvio está que a matéria-prima, a variedade, a composição química e uma série de fatores intrínsecos são essenciais na determinação do volume e concentração de inóculo, entretanto, de uma maneira geral, o inóculo tem

${ }^{1}$ HRONCEK, J. \& MALIK, F. Vinohrad, Brat is lava, 11(6):139, 1973.

2 WASILENSHI, Z. Poradnik Mikrobiologia w Przemyste Fermentacyjnyn i owocowo-warzywnzm' Zbiorowo. Wydawnictwo Przemys lu Lekkiego i Spozywczego, Warszawa. 1958.

${ }^{3}$ SALLER, W. Deutsche Weinzeitung, Ma inz, 90: 540, 562, 564, 1954. 
sido pequeno o suficiente para evitar rápidas elevações de temperatura produzidas pela rápida elevação da velocidade de fermentação, e, também, porque alguns vinhos produzidos com maiores concentrações de células, embora com grande ganho de produtividade, não se ter produzido vinhos de qualidade como pode ser observado no trabalho de reciclo de células e incremento de produção de vinho de uva realizado por ROSINI (1986). Nesse trabalho, o autor utilizou-se de inóculos em sete rodadas subseqüentes variando de 0,32 a $25,20 \mathrm{~g} / 1$ de massa celular seca ou equivalente a 1,06 a $84,0 \mathrm{~g} / \mathrm{l}$ de fermento prensado, obtendo vinhos de mesa comuns ou para posterior destilação, embora utilizado linhagem selecionada de levedura não produtora de $\mathrm{H}_{2} \mathrm{~S}$.

Quanto a variação de processo de condução, a citação bibliográfica é pobre e encontra-se apenas a condução do processo em batelada e em contínuo, na Itália. O trabalho de ROSINI (1986) traz resultados de CRBF - "cell - recycle - batch fermentation" uma variante com reutilização de fermento.

Utilizou-se durante os experimentos, alimentação escalonada a cada $24 \mathrm{~h}$, sendo $25 \%$ do volume total a cada vez, como será descrito em 4.4 .

Particularidades de cada experimento serão relatados e discutidos individualmente no decorrer do texto. 
4.3.1. Escolha da concentração celular inicial

\subsubsection{Primeiro experimento em batelada}

\section{Condições experimentais}

Concentração do mosto em ART $=190,30 \mathrm{~g} / 1$

Volume total do mosto $=9,7$ litros

Inóculo de fermento prensado, em massa seca $=15,80 \mathrm{~g} / 1$

Mel de laranjeira $=2,5 \mathrm{Kg}$

Agitação $=100 \mathrm{rpm}$

Ajuste de $\mathrm{pH}=1,5 \mathrm{~g} / 1$ de ácido círicico

Correção mineral: $1,587 \mathrm{~g} / 1$ de sulfato de amônio

$0,502 \mathrm{~g} / 1$ de fosfato de potássio

$0,185 \mathrm{~g} / 1$ de cloreto de magnésio 
Tabela 8. Resultados do 10 experimento de fermentação em batelada com fermento prensado.

\begin{tabular}{|c|c|c|c|c|c|c|c|c|}
\hline $\begin{array}{c}\text { AMOSTRA } \\
\text { (no) }\end{array}$ & $\begin{array}{c}\text { TEMPO1 } \\
\text { (h) }\end{array}$ & $\begin{array}{c}\text { TEMPERAT. } \\
\left({ }^{\circ} \mathrm{C}\right)\end{array}$ & $\mathrm{pH}$ & $\begin{array}{c}\text { LEVEDURA } \\
\text { m.s. } \\
(\mathrm{g} / \mathrm{l})\end{array}$ & $\begin{array}{l}\text { ÁLCOOL } \\
(\mathrm{ml} / 100 \mathrm{ml})\end{array}$ & $\begin{array}{l}\text { A.R.T } \\
(g / l)\end{array}$ & $\begin{array}{l}\text { ACIDEZ } \\
\text { TOTAL } \\
\text { (g/100ml) }\end{array}$ & $\begin{array}{l}\text { ACIDEZ } \\
\text { VOLÁTIL } \\
\text { (g/100ml) }\end{array}$ \\
\hline 1 & 0 & 21,0 & 3,16 & 15,80 & - & 190,30 & - & - \\
\hline 2 & 14,5 & 25,0 & 2,50 & 17,02 & 4,75 & 117,79 & 1,11 & - \\
\hline 3 & 21,5 & 25,0 & 2,45 & 17,86 & 6,18 & 97,57 & 1,20 & - \\
\hline 4 & 38,0 & 23,0 & 2,59 & 20,16 & 9,14 & 32,52 & 1,14 & 0,110 \\
\hline 5 & 40,5 & 23,0 & 2,56 & - & 9,96 & - & - & - \\
\hline 6 & 44,5 & 25,0 & 2,44 & 22,28 & 10,63 & 21,06 & 1,13 & 0,110 \\
\hline 7 & 46,0 & 25,0 & 2,46 & - & 10,87 & - & - & - \\
\hline 8 & 47,0 & 25,0 & 2,45 & 23,73 & 10,97 & 15,76 & 1,05 & 0,110 \\
\hline 9 & 48,0 & 25,0 & 2,44 & - & 10,97 & - & - & - \\
\hline 10 & 48,0 & 25,0 & 2,45 & - & 11,31 & 14,52 & 1,01 & 0,090 \\
\hline $\begin{array}{l}\text { AMOSTRA } \\
\text { (no) }\end{array}$ & $\begin{array}{c}\text { TEMPO1 } \\
\text { (h) }\end{array}$ & \multicolumn{2}{|c|}{$\begin{array}{c}\text { LEVEDURA } \\
\text { m.s. } \\
\text { (g) }\end{array}$} & $\begin{array}{l}\text { ÁLCOOL } \\
(\mathrm{g} / 100 \mathrm{ml})\end{array}$ & $\begin{array}{l}\text { A.R.T. } \\
\text { (g) }\end{array}$ & \multicolumn{2}{|r|}{$\begin{array}{l}\text { ACIDEZ } \\
\text { TOTAL } \\
\text { (g) }\end{array}$} & $\begin{array}{c}\text { ACIDEZ } \\
\text { VOLÁTIL } \\
\text { (g) }\end{array}$ \\
\hline 1 & 0 & \multicolumn{2}{|l|}{153,26} & - & $1.845,91$ & \multicolumn{2}{|r|}{ - } & - \\
\hline 2 & 14,5 & \multicolumn{2}{|l|}{165,09} & 3,75 & $1.142,56$ & \multicolumn{2}{|r|}{107,67} & - \\
\hline 3 & 21,5 & \multicolumn{2}{|l|}{173,24} & 4,88 & 946,43 & \multicolumn{2}{|r|}{116,40} & - \\
\hline 4 & 38,0 & \multicolumn{2}{|l|}{195,55} & 7,22 & 315,44 & \multicolumn{2}{|r|}{110,58} & 10,67 \\
\hline 5 & 40,5 & \multicolumn{2}{|l|}{ - } & 7,87 & - & \multicolumn{2}{|r|}{ - } & - \\
\hline 6 & 44,5 & \multicolumn{2}{|l|}{216,12} & 8,39 & 204,28 & \multicolumn{2}{|r|}{109,61} & 10,67 \\
\hline 7 & 46,0 & \multicolumn{2}{|l|}{ - } & 8,59 & - & \multicolumn{2}{|r|}{ - } & - \\
\hline 8 & 47,0 & \multicolumn{2}{|l|}{230,18} & 8,66 & 152,87 & \multicolumn{2}{|r|}{101,85} & 10.67 \\
\hline 9 & 48,0 & \multicolumn{2}{|l|}{ - } & 8,66 & - & \multicolumn{2}{|r|}{ - } & - \\
\hline 10 & 49,0 & \multicolumn{2}{|l|}{ - } & 8,93 & 140,84 & \multicolumn{2}{|r|}{97,97} & 8,73 \\
\hline
\end{tabular}

\footnotetext{
1 - Tempo de fermentação.
} 


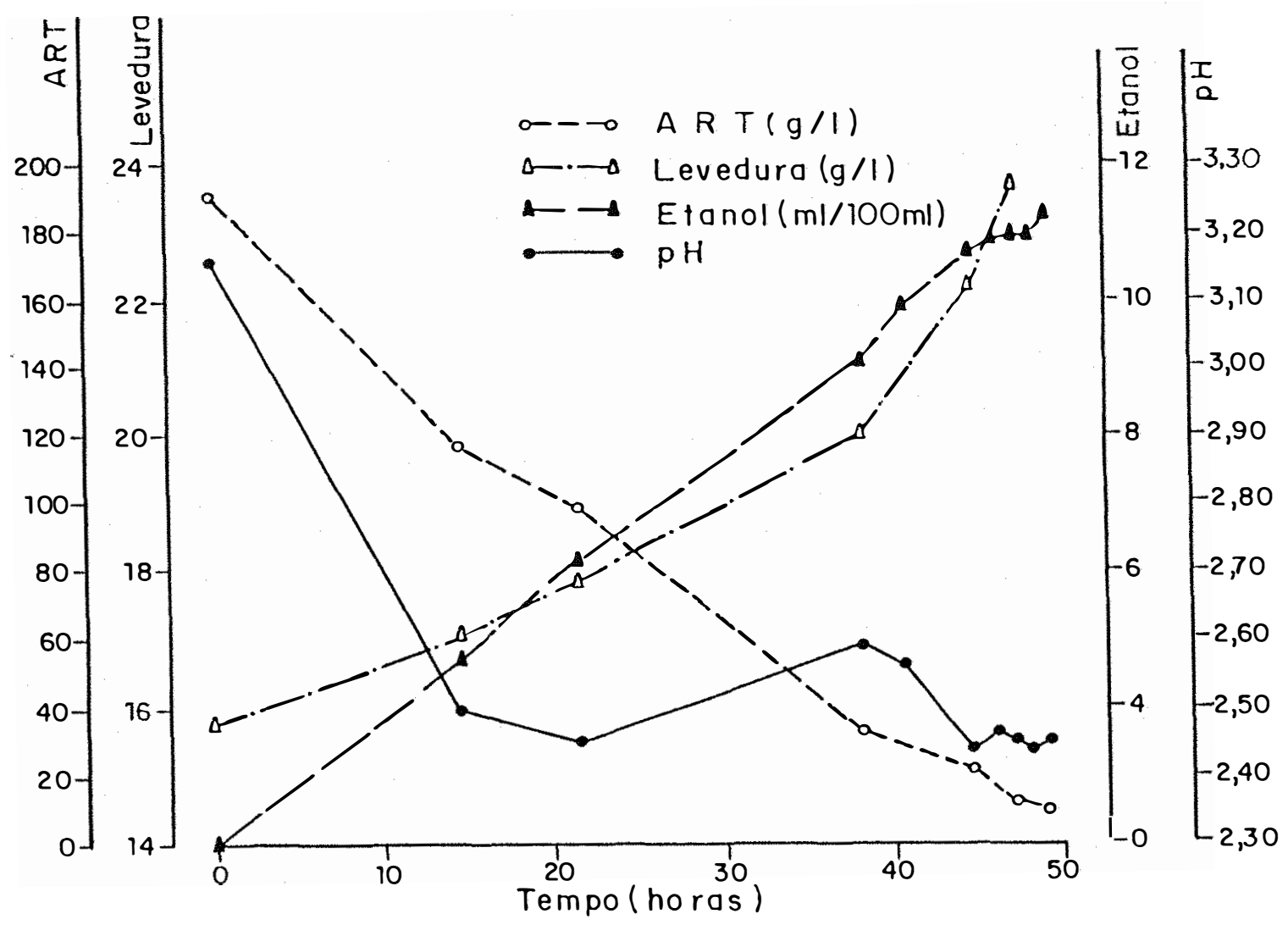

Figura 2-Acúcares redutores totais, massa celular, etanol e pH para o 7 . experimento de fermentaçāo em batelada.

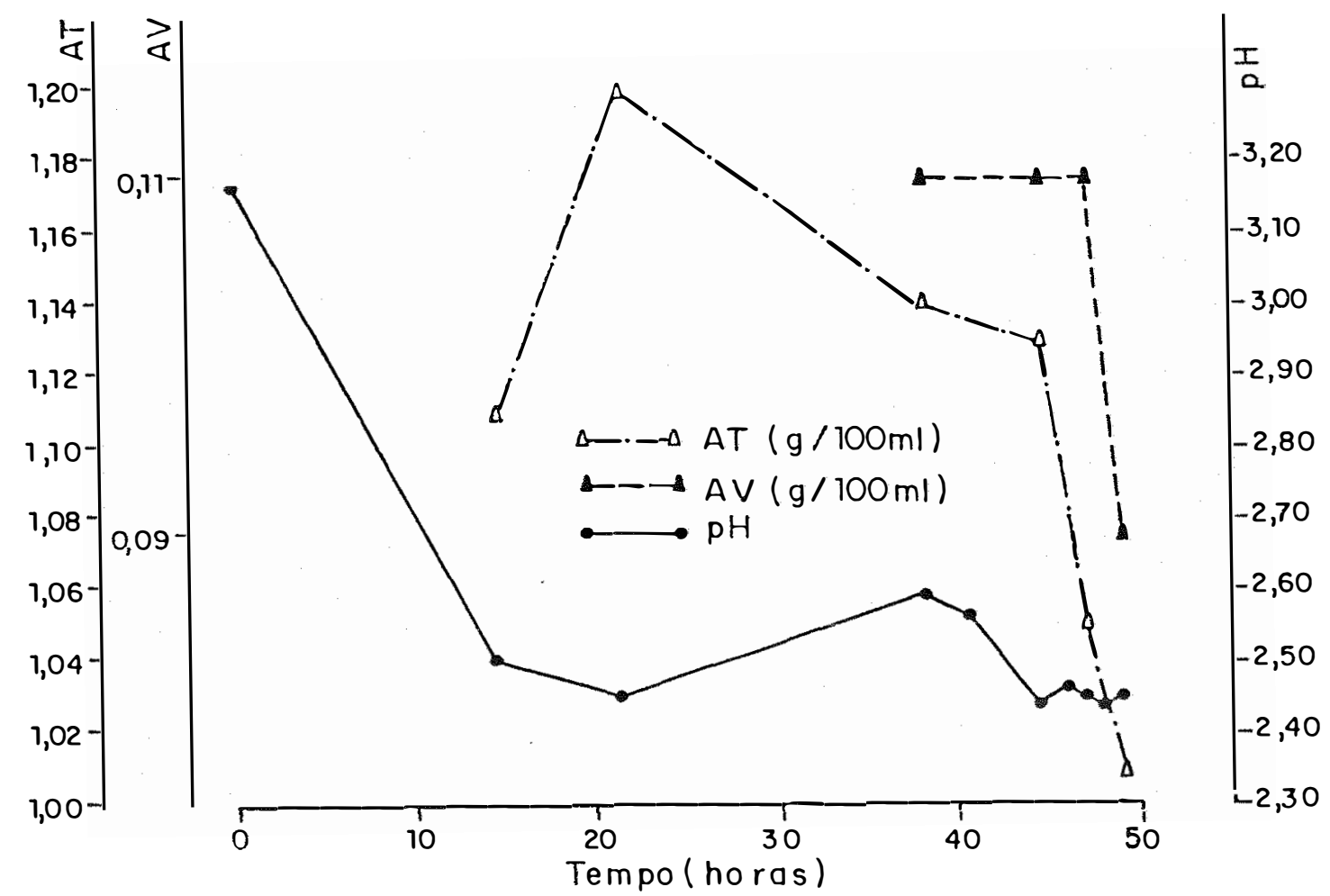

Figura 3-Ácidos totais (AT), ácidos voláteis (AV) e pH para o 1: experimento de fermentaçăo em batelada. 
Uma vez que as dornas de fermentação utilizadas nos experimentos possuiam resfriamento através de sistema de camisa interna ligada a um banho com temperatura controlada, foi efetuada uma rodada de fermentação com alta concentração celular 15,8 g/l massa seca, e cujas condições experimentais estão apresentadas junto a Tabela 8 e Figuras 2 e 3 .

O mosto foi obtido pela diluição de mel de laranjeira com água destilada, aproximadamente de 1:4 obtendo-se concentração de açúcares da ordem de 180-200g/l o que permitiu a obtenção de um vinho, de acordo com as condições físico químicas do meio e concentração de inóculo, entre 10 e $11 \%$ de álcool em volume.

Para o hidromel, embora a literatura cite graus variáveis, até $14 \%$ de álcool, na prática, valores elevados, superiores a $10-11 \%$ produzem, na maior parte das vezes, gosto ligeiramente amargo, desagrádavel e acentuadamente alcóolico no tipo vinho seco, se assim puder ser expresso.

O experimento foi acompanhado durante 49 horas quando se deu por terminada a fermentação principal. Amostras foram retiradas em intervalos irregulares de tempo, porém suficiente para acompanhamento da fermentação. As alíquotas foram analisadas quanto a concentração celular, $\mathrm{pH}$, açúcares redutores, acidez total e volátil no vinho em fermentação.

A elevada massa celular deu condições a um aumento de $50 \%$ na massa seca permitindo que de um volume inicial de $5,2 \%$ passasse para $7,9 \%$ no final da fermentação utilizando cálculo segundo KOSHIMIZU et al. (1982). A acidez total 
obtida foi $1,01 \mathrm{~g} / 100 \mathrm{ml}$, com uma acidez volátil de $0,09 \mathrm{~g} / 100 \mathrm{ml}$. A acidez total está acima dos padrões preconizados para vinho na legislação nacional (Brasil, s.d.).

Mesmo comparando-se aos resultados de ROSINI (1986) que são de 0,32 a $25,2 \mathrm{~g} / 1$ massa seca inicial e de etanol da ordem de 8,5 a 9,2 , a acidez total esteve em torno de 0,9 a $0,937 \mathrm{~g} / 100 \mathrm{ml}$ e a volátil entre 0,024 a $0,052 \mathrm{~g} / 100 \mathrm{ml}$, além de $\mathrm{pH}$ variando entre 2,82 a 2,96 .

No presente experimento o $\mathrm{pH}$ variou de 3,16 a 2,44 no final do processo. A produtividade volumétrica em etanol expressa em $\mathrm{ml.} .^{-1} \mathrm{~h}^{-1}$ foi de 2,31 contra 9,87 de ROSINI (1986) em condições aproximadamente semelhantes. Todavia, tratava-se de mosto de uva clarificado, e a linhagem de levedura, selecionada para vinho de uva e não produtora de $\mathrm{H}_{2} \mathrm{~S}$. Provavelmente está aŕ o principal fator que permite avanço de tecnologia e ganho de produtividade, pois, em caso contrário, temos que trabalhar sempre com reduzido inóculo para não afetar o organoléptico, como veremos no presente caso.

Não foi analisado extrato seco no produto em estudo.

Com o vinho considerado terminado quanto a fermentação, procedeu-se a centrifugação para a separação do fermento e o sobrenadante foi filurado em funil contendo CELITE 503 como auxiliar de filtração para remoção de partículas e células residuais, como descrito em 3.9.4.

Ao vinho não maturado, foi procedido um teste de percepção de sabor, aroma e odor, não comparativo pela falta de amostra comercial, principalmente o tipo seco. Participaram pelo menos cerca de seis pessoas, sempre que possível. 
Esse primeiro ensaio resultou em produto com sabor e aroma a fermento, como classifica PEYNAUD (1987) tão acentuado e desagradável que o odor de mel de laranjeira ficou totalmente encoberto e indistinguível. Esse experimento não recebeu repetições nem para análises químicas, para detecção de possíveis causadores do mau gosto e cheiro, por fugir ao escopo do presente trabalho.

\subsubsection{Segundo experimento em batelada}

\section{Condições experimentais}

Concentração do mosto em ART $=183,04 \mathrm{~g} / 1$

Volume total do mosto $=10,0$ litros

Inóculo de fermento prensado, em massa seca $=2,93 \mathrm{~g} / 1$

Mel de laranjeira $=2,3 \mathrm{Kg}$

Agitação $=100 \mathrm{rpm}$

Ajuste de $\mathrm{pH}=1,5 \mathrm{~g} / 1$ de ácido círico

Correção mineral: 1,587 g/1 de sulfato de amônio

$0,502 \mathrm{~g} / 1$ de fosfato de potássio

$0,185 \mathrm{~g} / 1$ de cloreto de magnésio 
Tabela 9. Resultados do 20 experimento de fermentação em batelada com fermento prensado.

\begin{tabular}{|c|c|c|c|c|c|c|c|c|}
\hline $\begin{array}{l}\text { AMOSTRA } \\
\text { (no) }\end{array}$ & $\begin{array}{l}\text { TEMPO } 1 \\
\text { (h) }\end{array}$ & $\begin{array}{l}\text { TEMPERAT. } \\
\left({ }^{\circ} \mathrm{C}\right)\end{array}$ & $\mathrm{pH}$ & $\begin{array}{c}\text { LEVEDURA } \\
\text { m.s. } \\
(g / l)\end{array}$ & $\begin{array}{c}\text { ÁLCOOL } \\
(\mathrm{ml} / 100 \mathrm{ml})\end{array}$ & $\begin{array}{l}\text { A.R.T } \\
(g n)\end{array}$ & $\begin{array}{c}\text { ACIDEZ } \\
\text { TOTAL } \\
\text { (g/100ml) }\end{array}$ & $\begin{array}{r}\text { ACIDEZ } \\
\text { VOLÁTIL } \\
\text { (g/100ml) }\end{array}$ \\
\hline 1 & 0 & 25,0 & 3,43 & 2,93 & - & 183,04 & 0,23 & 0,010 \\
\hline 2 & 3,0 & 25,0 & 2,83 & 4,30 & 0,83 & 171,10 & 0,38 & 0,010 \\
\hline 3 & 17,0 & 25,0 & 2,32 & 6,84 & 3,53 & 116,08 & 0,43 & 0,030 \\
\hline 4 & 21,0 & 26,5 & 2,22 & 6,84 & 4,10 & 106,55 & 0,52 & 0,050 \\
\hline 5 & 25,0 & 27,0 & 2,25 & - & 4,61 & 98.08 & 0,53 & 0,050 \\
\hline 6 & 40,0 & 26,0 & 2,38 & 6,98 & 7,04 & 60,53 & 0,55 & 0,060 \\
\hline 7 & 48,0 & 27,0 & 2,39 & 7,35 & 8,16 & 48,13 & 0,57 & 0,060 \\
\hline 8 & 64,0 & 26,0 & 2,39 & 6,75 & 9,63 & 20,34 & 0,61 & 0,070 \\
\hline 9 & 70,5 & 27,0 & - & - & 9,96 & - & - & - \\
\hline 10 & 71,5 & 29,0 & - & - & 10,13 & - & - & - \\
\hline 11 & 72,5 & 29,0 & 2,50 & 7,07 & 10,13 & 11,42 & 0,65 & 0,060 \\
\hline 12 & 88,0 & 25,0 & 2,43 & 7,19 & 10,47 & 6,37 & 0,58 & 0,070 \\
\hline $\begin{array}{c}\text { AMOSTRA } \\
\left(n^{Q}\right)\end{array}$ & $\begin{array}{l}\text { TEMPO' } \\
\text { (h) }\end{array}$ & $\begin{array}{l}\text { LEVEDURA } \\
\text { m.s. } \\
\text { (g) }\end{array}$ & & $\begin{array}{l}\text { LCOOL } \\
g(100 \mathrm{ml})\end{array}$ & $\begin{array}{l}\text { A.R.T. } \\
\text { (g) }\end{array}$ & $\begin{array}{c}\text { ACIDEZ } \\
\text { TOTAL } \\
\text { (g) }\end{array}$ & & $\begin{array}{l}\text { ACIDEZ } \\
\text { VOLÁTIL } \\
\text { (g) }\end{array}$ \\
\hline 1 & 0 & 29,30 & & - & $1.830,43$ & 23,0 & & 1,0 \\
\hline 2 & 3,0 & 43,00 & & 0,66 & $1.711,00$ & 38,0 & & 1,0 \\
\hline 3 & 17,0 & 68,40 & & 2,78 & $1.160,80$ & 43,0 & & 3,0 \\
\hline 4 & 21,0 & 68,40 & & 3,23 & $1.160,50$ & 52,0 & & 5,0 \\
\hline 5 & 25,0 & - & & 3,64 & 980,80 & 53,0 & & 5,0 \\
\hline 6 & 40,0 & 69,80 & & 5,55 & 605,30 & 55,0 & & 6,0 \\
\hline 7 & 48,0 & 73,50 & & 6,44 & 481,30 & 57,0 & & 6,0 \\
\hline 8 & 64,0 & 67,50 & & 7,61 & 203,40 & 61,0 & & 7,0 \\
\hline 9 & 70,5 & - & & 7,87 & - & - & & - \\
\hline 10 & 71,5 & - & & 7,99 & - & - & & - \\
\hline 11 & 72,5 & 70,70 & & 7,99 & 114,20 & 65,0 & & 6,0 \\
\hline 12 & 88,0 & 71,90 & & 8,26 & 63,70 & 58,0 & & 7,0 \\
\hline
\end{tabular}

1 - Tempo de fermentação. 


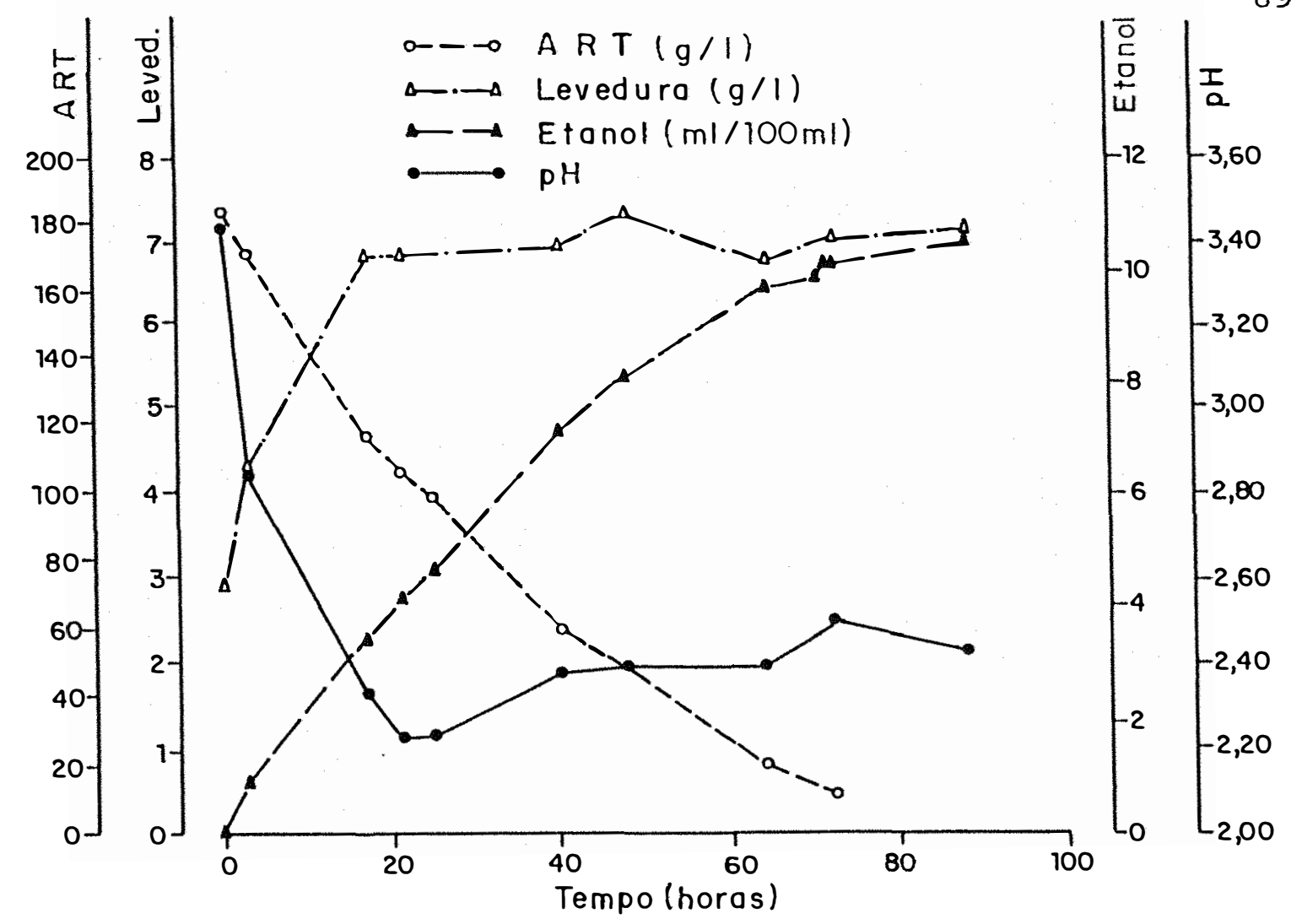

Figura 4-Acúcores redutores totais, massa celular, etanol e pH para o $2^{\circ}$. experimento de fermentaçōo em batelada.

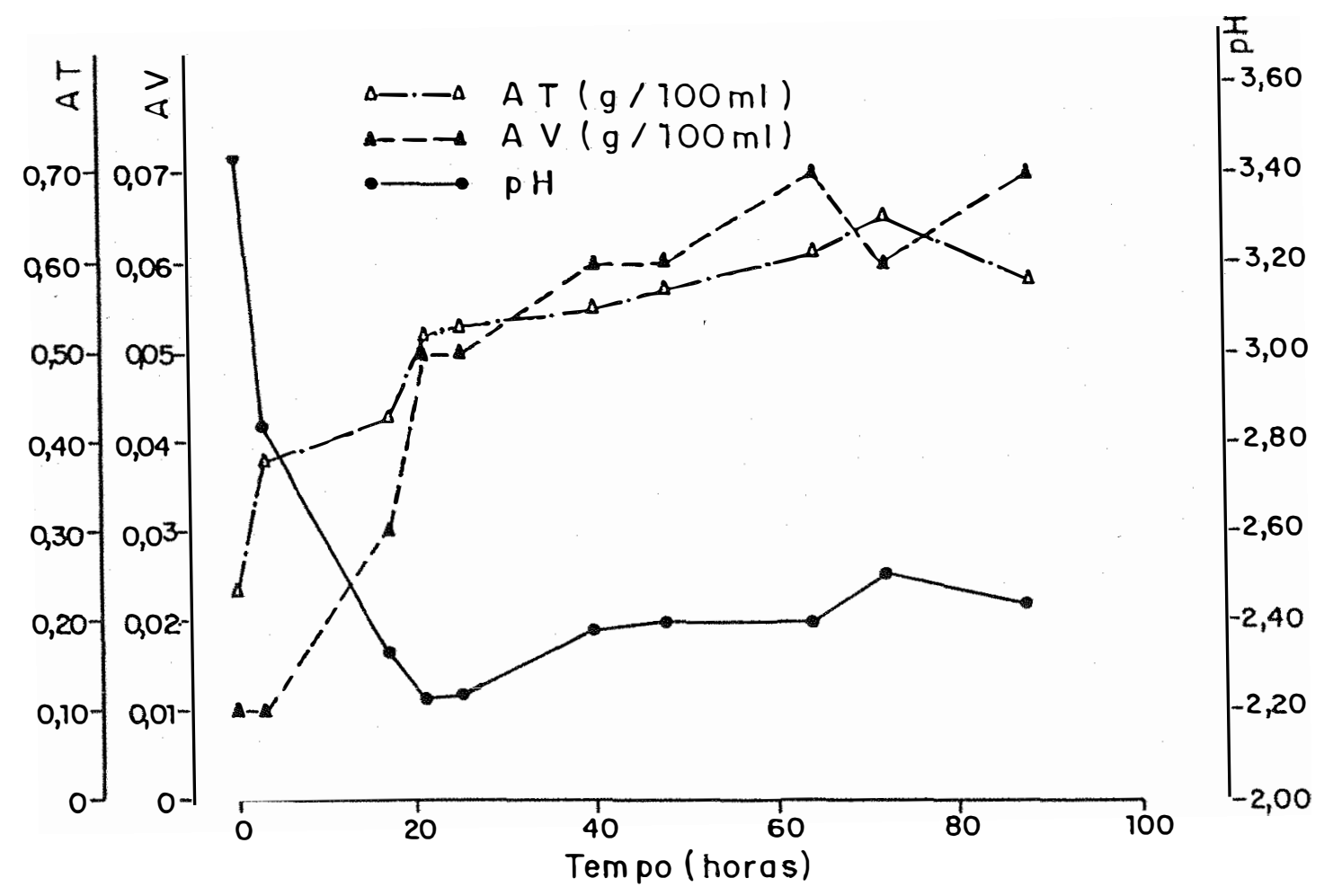

Figura 5-Ácidos totais ( $A T$ ), ácidos voláteis ( $A V$ ) e pH para 02 : experimento de fermentaçōo em batelada. 
Foi conduzida uma nova fermentação em batelada convencional, com preparo de mosto segundo descrito no ensaio anterior.

No segundo experimento, a massa inicial de células foi reduzida para a concentração de $2,93 \mathrm{~g} / 1$ de massa seca ou aproximadamente $1 \%$ em volume, para evitar que mesmo a essa concentração pudesse haver influência dos adjuntos do fermento prensado comercial.

Com esse objetivo foi tentado um pequeno tratamento com mel, tanto para aclimatar as leveduras, como reduzir odor e aroma do fermento e aumentar o odor e aroma originais do mel.

O mel foi diluido para obter-se $300 \mathrm{ml}$ de solução a $10 \%$ ao qual foi adicionado ácido cítrico até pH 3,0. Foi então adicionado $167 \mathrm{~g}$ de fermento prensado comercial e deixado a temperatura ambiente, em repouso, com agitação manual periódica. Após 24 horas, a suspensão foi centrifugada a 800 x g por 10 minutos e o sobrenadante desprezado. Suspendeu-se o sedimento com água destilada para proceder-se lavagem e a seguir novamente centrifugada nas mesmas condições anteriores.

Ao sedimento foi adicionada nova solução de mel a $5 \%$, ajustada também pH 3,0 com ácido cítrico e em volume igual a $250 \mathrm{ml}$. Após 72 horas, repetiuse a centrifugação, lavagem, recentrifugação e o sedimento foi ressuspenso agora no mosto de mel do segundo experimento propriamente dito, retirando-se amostra para determinação da concentração inicial de células a 0 hora. As demais condições experimentais estão descritas no protocolo do experimento apresentado junto a Tabelas 9 e Figuras 4 e 5. 
Conforme os dados constante da Tabela 9 a fermentação foi acompanhada por 88 horas ou 3,6 dias quando foi considerada terminada, com açúcar residual de apenas $6,37 \mathrm{~g} / \mathrm{l}$ e teor alcóolico estabilizado ao redor de $10,3 \%$, em volume. A temperatura variou de $25^{\circ} \mathrm{C}$ a $29^{\circ} \mathrm{C}$, porém a maior parte do tempo entre 25 a $27^{\circ} \mathrm{C}$ e $\mathrm{o} \mathrm{pH}$ sofrendo uma queda brusca nas primeiras 24 horas, correspondente ao crescimento mais intenso, provavelmente a fase de crescimento exponencial ou logaritŕmica, onde, além do crescimento em $\mu$ máximo e constante, a produção de ácidos orgânicos, principalmente o ácido succínico, é produzido em maior proporção (CONWAY \& BRADY, 1950; CONWAY \& DOWNEY, 1950; SIGLER et al., 1981).

A produtividade volumétrica de $1,19 \mathrm{ml} \cdot \mathrm{l}^{-1} \cdot \mathrm{h}^{-1}$ foi sempre muito menor que a obtida por ROSINI (1986) entretanto, se comparado a outros autores como MAUGENET (1964) que cita 20 a 30 dias para a fermentação do mel a 20 a $25^{\circ} \mathrm{C}$ ou ADAMS \& NIESEN (1963) que faz menção de 6 meses ou mais, e ainda STEINKRAUS \& MORSE (1966) que recomendam duas semanas, veremos que a literatura é conflitante e geralmente muito baixa em relação a esta fermentação de 3,6 dias.

Todavia, essa produtividade obtida também foi desprovida de sentido após o teste de percepção de flavor e buquê a que foi submetido o produto. Ainda que mais atenuado que o primeiro ensaio, este segundo experimento revelou-se com aroma e sabor a fermento, ácido e sem odor a mel.

Embora outros itens como acidez total, fixa e volátil estivessem dentro dos padrões de qualidade exigidos pela SIPV - Secretaria de Inspeção de Produto Vegetal (BRASIL, s.d.) o mesmo não apresentou características desejáveis de uma bebida. 


\subsubsection{Terceiro experimento em batelada}

\section{Condições experimentais}

Concentração do mosto em ART $=165,55 \mathrm{~g} / 1$

Volume total do mosto $=10,0$ litros

Inóculo de fermento prensado, em massa seca $=0,96 \mathrm{~g} / 1$

Mel de laranjeira $=2,3 \mathrm{~kg}$

Agitação $=100 \mathrm{rpm}$

Ajuste de $\mathrm{pH}=1,5 \mathrm{~g} / 1$ de ácido cítrico

Correção mineral: $1,587 \mathrm{~g} / 1$ de sulfato de amônio

$0,502 \mathrm{~g} / 1$ de fosfato de potássio

$0,185 \mathrm{~g} / 1$ de cloreto de magnésio 
Tabela 10. Resultados do 30 experimento de fermentação em batelada com fermento prensado.

\begin{tabular}{|c|c|c|c|c|c|c|c|c|}
\hline $\begin{array}{l}\text { AMOSTRA } \\
\text { (no) }\end{array}$ & $\begin{array}{l}\text { TEMPO } 1 \\
\text { (h) }\end{array}$ & $\begin{array}{l}\text { TEMPERAT. } \\
\left({ }^{\circ} \mathrm{C}\right)\end{array}$ & $\mathrm{pH}$ & $\begin{array}{c}\text { LEVEDURA } \\
\text { m.s. } \\
(g /)\end{array}$ & $\begin{array}{c}\text { ÁLCOOL } \\
(\mathrm{ml} / 100 \mathrm{ml})\end{array}$ & $\begin{array}{l}\text { A.R.T } \\
(g / l)\end{array}$ & $\begin{array}{c}\text { ACIDEZ } \\
\text { TOTAL } \\
(g / 100 \mathrm{ml})\end{array}$ & $\begin{array}{r}\text { ACIDEZ } \\
\text { VOLÁTIL } \\
(\mathrm{g} / 100 \mathrm{ml})\end{array}$ \\
\hline 1 & 0,0 & 26,0 & 3,80 & 0,96 & - & 165,55 & 0,20 & 0,006 \\
\hline 2 & 24,0 & 27,0 & 2,30 & 4,25 & 3,81 & 98,94 & 0,48 & 0,023 \\
\hline 3 & 48,0 & 23,0 & 2,43 & 4,33 & 6,49 & 55,43 & 0,54 & 0,028 \\
\hline 4 & 72,0 & 25,0 & 2,44 & 4,84 & 8,48 & 24,70 & 0,54 & 0,028 \\
\hline 5 & 96,0 & 24,0 & 2,50 & 4,84 & 10,05 & 7,03 & 0,51 & 0,028 \\
\hline 6 & 120,0 & 24,0 & 2,58 & 4,93 & 9,96 & 6,28 & 0,48 & 0,014 \\
\hline 7 & 126,5 & 24,0 & - & - & 9,96 & - & $\ldots$ & \\
\hline $\begin{array}{l}\text { AMOSTRA } \\
\text { (no) }\end{array}$ & $\begin{array}{c}\text { TEMPO1 } \\
\text { (h) }\end{array}$ & $\begin{array}{c}\text { LEVEDU } \\
\text { m.s. } \\
\text { (g) }\end{array}$ & & $\begin{array}{l}\text { ÁLCOOL } \\
(\mathrm{g} / 100 \mathrm{ml})\end{array}$ & $\begin{array}{l}\text { A.R.T. } \\
\text { (g) }\end{array}$ & $\begin{array}{c}\text { ACIDEZ } \\
\text { TOTAL } \\
\text { (g) }\end{array}$ & & $\begin{array}{l}\text { CIDEZ } \\
\text { OLÁTIL } \\
\text { (g) }\end{array}$ \\
\hline 1 & 0,0 & 9,60 & & - & $1.655,50$ & 20,0 & & 0,60 \\
\hline 2 & 24,0 & 42,50 & & 3,01 & 981,40 & 48,0 & & 2,30 \\
\hline 3 & 48,0 & 43,30 & & 5,12 & 554,30 & 54,0 & & 2,80 \\
\hline 4 & 72,0 & 48,40 & & 6,69 & 247,00 & 54,0 & & 2,80 \\
\hline 5 & 96,0 & 48,40 & & 7,93 & 70,30 & 51,0 & & 2,80 \\
\hline 6 & 120,0 & 49,30 & & 7,87 & 62,80 & 48,0 & & 1,40 \\
\hline 7 & 126,5 & - & & 7,87 & - & - & & - \\
\hline
\end{tabular}

1 - Tempo de fermentação. 


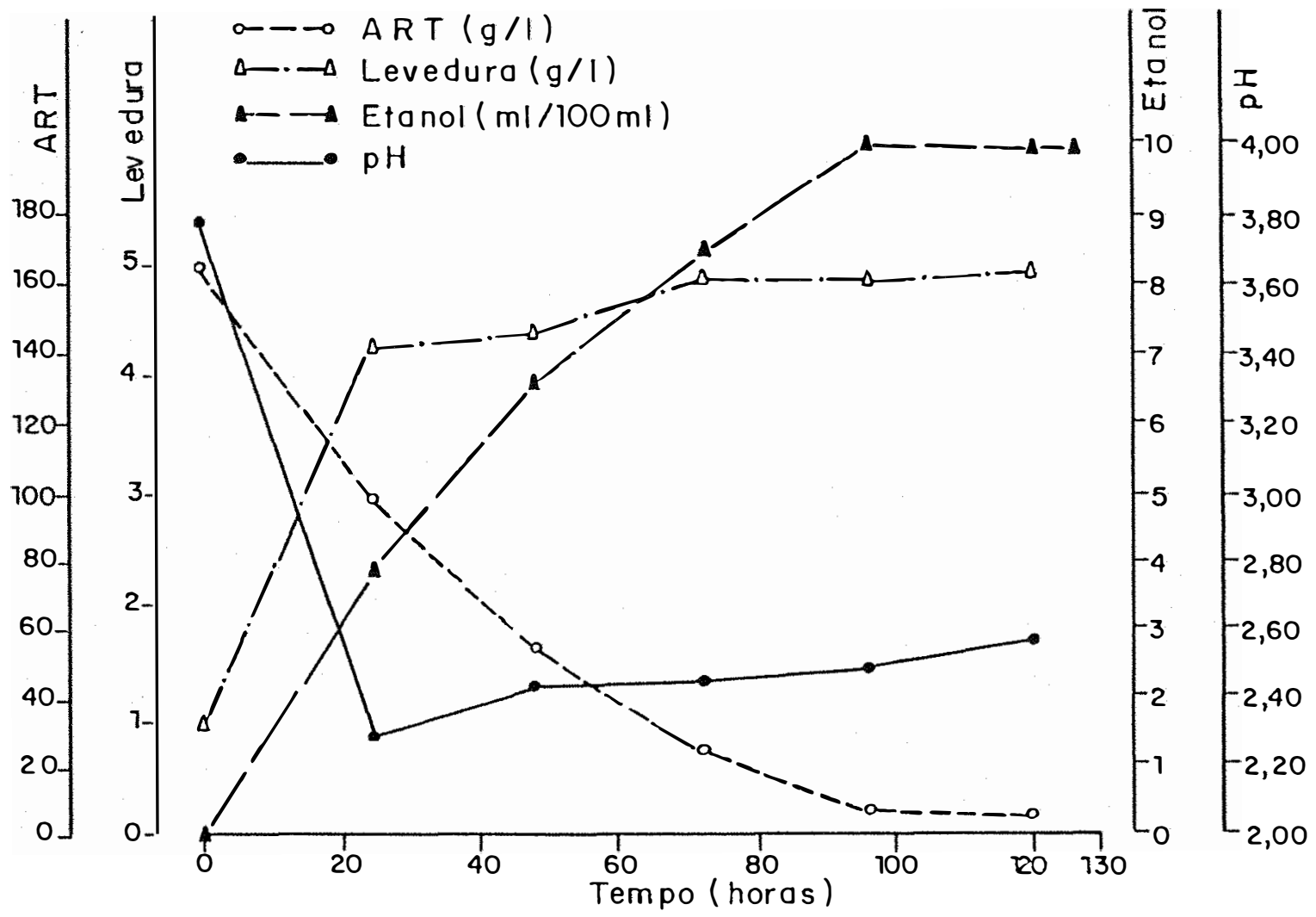

Figura 6-Acúcares redutores totais, massa celular, etanol e pH para o $3^{\circ}$ experimento de fermentacão em batelada.

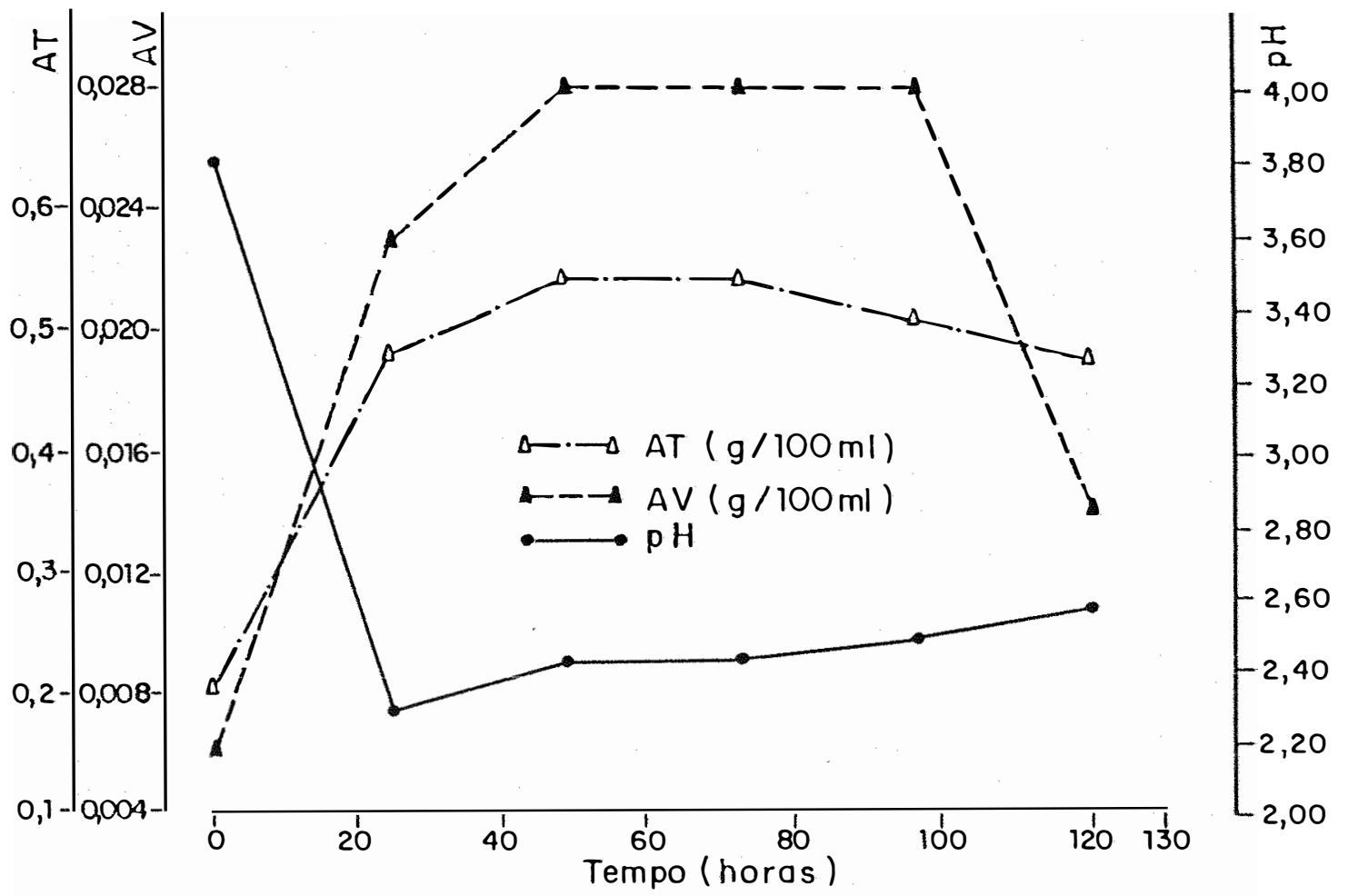

Figura 7-Ácidos totais ( $A T$ ), ácidos volateis ( $A V$ ) e $\mathrm{pH}$ para 0 30 experimento de fermentação em batelada. 
O fato de ter reduzido o inóculo do segundo ensaio e ainda ter-se efetuado um tratamento prévio com o próprio mel mostrou que ainda não se houvera atingido nível de inóculo desejável pelo menos com essa linhagem de levedura.

Foi então reduzida a massa seca de inóculo para cerca de $1.0 \mathrm{~g} / 1$ ou $3,3 \mathrm{~g}$ de fermento prensado por litro, equivalente a $0,3 \%$ em volume.

As demais condições de suplementação mineral e correção de pH foram idênticos ao primeiro e segundo experimento.

Os resultados obtidos estão apresentados na Tabela 10 e Figuras 6 e 7.

Foi considerada terminada a fermentação quando tendem a repetir o teor alcóolico em duas amostragens consecutivas. Considerou-se terminada após 120 horas de fermentação ou 5 dias, tendo diminuido em $30 \%$ a produtividade volumétrica, caindo para $0,83 \mathrm{ml} \cdot \mathrm{I}^{-1} \cdot \mathrm{h}^{-1}$ respectivamente, quando se reduziu o inóculo inicial de cerca de 3,0 para 1,0 g de matéria seca por litro. Assim, para uma redução de $66 \%$ na massa celular correspondeu a apenas $30,0 \%$ de redução de produtividade.

O aumento de novas células correspondeu a $80,53 \%$, e como mostrado por ROSINI (1986), ao menor inóculo corresponde o maior acréscimo percentual em novas células embora também a menor massa inicial corresponda a menor massa final.

O grande crescimento de massa celular observado correspondeu às 24 horas iniciais quando então passou a ter acréscimos pequenos a cada 24 horas, possívelmente limitado pelo $\mathrm{pH}$. Como para um grande crescimento celular em anaerobiose corresponde uma intensa formação de ácidos orgânicos como o succínico, 
acético e láctico e tendo o meio de mel pouco poder tamponante devido a debilidade de sais minerais, o pH pode atingir níveis não só limitantes ao crescimento como capazes de afetar a membrana celular e a viabilidade (PAMPULHA \& LOUREIRO-DIAS, 1989). Embora o crescimento tenha se reduzido muito após as 24 horas iniciais, a formação de álcool permaneceu elevada, proporcional ao açúcar consumido.

Como as análises de álcool e acidez total, fixa e volátil estão dentro das normas de identidade e qualidade estabelecidas pela SIPV, se o organoléptico ou sensorial fosse favorável, teríamos estabelecido um parâmetro aproximado para concentração celular inicial e outros parâmetros de condução da fermentação.

Os provadores que nos auxiliaram deram a indicação apenas que o sabor estava melhorando ou mais agrádavel que os dois ensaios anteriores e que o produto já apresentava um ligeiro odor a mel embora também contivesse aroma e sabor a fermento.

Com isso concluimos que a concentração celular inicial era ainda elevada o suficiente para reprovar o produto. Para HARRISON \& GRAHAM (1970), na produção de álcool potável em processo em batelada, a contagem inicial deve estar em torno de $10^{7}$ células $/ \mathrm{ml}$ e a contagem final em cerca de $1,5 \times 10^{8}$ células $/ \mathrm{ml}$ (equivalentes a aproximadamente 0,1 e $1,5 \% \mathrm{p} / \mathrm{v}$ em fermento prensado, respectivamente). A concentração deste terceiro experimento, de $0,96 \mathrm{~g} / 1$ massa seca no inicio está ainda muito superior ao descrito pelos autores citados. 


\subsubsection{Quarto experimento em batelada}

\section{Condições experimentais ( $1^{\mathbf{a}}$ fermentação)}

Concentração do mosto em ART $=184,20 \mathrm{~g} / \mathrm{l}$

Volume total do mosto $=10,0$ litros

Inóculo, massa seca $=0,29 \mathrm{~g} / 1$

Levedura $=$ linhagem isolada do fermento prensado

Mel de laranjeira $=2,32 \mathrm{~g} / 1$

Agitação $=100 \mathrm{rpm}$

Ajuste de $\mathrm{pH}=1,5 \mathrm{~g} / 1$ de ácido cítrico

Correção mineral: $1,587 \mathrm{~g} / 1$ de sulfato de amônio

$0,502 \mathrm{~g} / 1$ de fosfato de potássio

$0,185 \mathrm{~g} / 1$ de cloreto de magnésio 
Tabela 11. Resultados da 1 a fermentação do 40 experimento em batelada, pela linhagem de levedura isolada do fermento prensado.

\begin{tabular}{|c|c|c|c|c|c|c|c|c|}
\hline $\begin{array}{l}\text { AMOSTRA } \\
\text { (no) }\end{array}$ & $\begin{array}{c}\text { TEMPO } 1 \\
\text { (h) }\end{array}$ & $\begin{array}{c}\text { TEMPERAT. } \\
\left({ }^{\circ} \mathrm{C}\right)\end{array}$ & $\mathrm{pH}$ & $\begin{array}{c}\text { LEVEDURA } \\
\text { m.s. } \\
(g / l)\end{array}$ & $\begin{array}{c}\text { ÁLCOOL } \\
(\mathrm{ml} / 100 \mathrm{ml})\end{array}$ & $\begin{array}{c}\text { A.R.T } \\
(g / l)\end{array}$ & $\begin{array}{c}\text { ACIDEZ } \\
\text { TOTAL } \\
\text { (g/100ml) }\end{array}$ & $\begin{array}{l}\text { ACIDEZ } \\
\text { VOLÁTIL } \\
(\mathrm{g} / 100 \mathrm{ml})\end{array}$ \\
\hline 1 & 0 & 28,0 & 4,00 & 0,29 & - & 184,20 & 0,10 & - \\
\hline 2 & 4,0 & 27,0 & 3,97 & 0,38 & 0,09 & 172,25 & 0,11 & - \\
\hline 3 & 21,5 & 25,0 & 2,35 & 1,80 & 1,44 & 148,34 & 0,25 & 0,011 \\
\hline 4 & 45,5 & 24,0 & 2,26 & 2,30 & 2,96 & 126,21 & 0,30 & 0,031 \\
\hline 5 & 69,5 & 24,0 & 2,30 & 2,54 & 4,10 & 105,33 & 0,38 & 0,056 \\
\hline 6 & 93,5 & 25,0 & 2,34 & 2,60 & 5,12 & 82,83 & 0,40 & 0,085 \\
\hline 7 & 117,5 & 24,0 & 2,35 & - & 5,65 & 73,54 & 0,42 & 0,096 \\
\hline 8 & 141,5 & 21,0 & 2,34 & 2,71 & 6,18 & 69.03 & 0,44 & 0,096 \\
\hline 9 & 165,5 & 20,0 & 2,36 & 2,61 & 6,49 & 66,73 & 0,45 & 0,107 \\
\hline
\end{tabular}

\section{AMOSTRA}

(no)

(h)

\begin{tabular}{lr}
\hline 1 & 0 \\
2 & 4,0 \\
3 & 21,5 \\
4 & 45,5 \\
5 & 69,5 \\
6 & 93,5 \\
7 & 117,5 \\
8 & 141,5 \\
9 & 165,5
\end{tabular}

LEVEDURA ÁLCOOL

m.s.

(g)
A.R.T.

(g)

ACIDEZ ACIDEZ
TOTAL

(g)
VOLÁTIL

(g)

\begin{tabular}{rcl}
\multicolumn{1}{c}{0} & 2,90 & - \\
4,0 & 3,80 & 0,07 \\
21,5 & 18,00 & 1,14 \\
45,5 & 23,00 & 2,34 \\
69,5 & 25,40 & 3,23 \\
93,5 & 26,00 & 4,04 \\
117,5 & - & 4,46 \\
141,5 & 27,10 & 4,88 \\
165,5 & 26,10 & 5,12
\end{tabular}

$1.842,00$
$1.722,50$
$1.483,40$
$1.262,10$
$1.053,30$
828,30
735,40
690,30
667,30

10,0

11,0

25,0

30,0

38,0

40,0

42,0

44,0

45,0

$-$

$-$

1,10

3,10

5,60

8,50

9,60

9,60

10,70

\footnotetext{
1 - Tempo de fermentação.
} 
Condições experimentais ( $2^{a}$ fermentação)

Concentração do mosto em ART $=181,11 \mathrm{~g} / 1$

Volume total do mosto $=10,0$ litros

Inóculo, massa seca $=0,35 \mathrm{~g} / 1$

Levedura $=S$. cerevisiae $(\mathrm{IZ}-888)$

Mel de laranjeira $=2,32 \mathrm{Kg}$

Agitação $=100 \mathrm{rpm}$

Ajuste de $\mathrm{pH}=1,5 \mathrm{~g} / 1$ de ácido cítrico

Correção mineral: $1,587 \mathrm{~g} / 1$ de sulfato de amônio

$0,502 \mathrm{~g} / 1$ de fosfato de potássio

0,185 g/1 de cloreto de magnésio 
Tabela 12. Resultados da 2 a fermentação do 40 experimento em batelada, pela linhagem de levedura S. cerevisiae (1Z-888).

\begin{tabular}{|c|c|c|c|c|c|c|c|c|}
\hline $\begin{array}{l}\text { AMOSTRA } \\
\text { (no) }\end{array}$ & $\begin{array}{l}\text { TEMPO1 } \\
\text { (h) }\end{array}$ & $\begin{array}{l}\text { TEMPERAT. } \\
\left({ }^{\circ} \mathrm{C}\right)\end{array}$ & $\mathrm{pH}$ & $\begin{array}{c}\text { LEVEDURA } \\
\text { m.s. } \\
(g i)\end{array}$ & $\begin{array}{c}\text { ÁLCOOL } \\
(\mathrm{ml} / 100 \mathrm{ml})\end{array}$ & $\begin{array}{c}\text { A.R.T } \\
(g / l)\end{array}$ & $\begin{array}{c}\text { ACIDEZ } \\
\text { TOTAL } \\
(\mathrm{g} / 100 \mathrm{ml})\end{array}$ & $\begin{array}{r}\text { ACIDEZ } \\
\text { VOLÁTIL } \\
\text { (g/100ml) }\end{array}$ \\
\hline 1 & 0 & 28,0 & 4,02 & 0,35 & - & 181,11 & 0,10 & - \\
\hline 2 & 4,0 & 28,0 & 3,99 & 0,47 & 0,09 & 178,61 & 0,12 & - \\
\hline 3 & 21,5 & 25,0 & 2,40 & 1,97 & 1,51 & 151,79 & 0,27 & 0,012 \\
\hline 4 & 45,5 & 24,5 & 2,26 & 2,97 & 3,39 & 117,92 & 0,32 & 0,033 \\
\hline 5 & 69,5 & 24,0 & 2,32 & 3,17 & 4,46 & 98,96 & 0,34 & 0,060 \\
\hline 6 & 93,5 & 25,0 & 2,36 & 3,21 & 5,12 & 82,61 & 0,37 & 0,078 \\
\hline 7 & 117,5 & 24,0 & 2,38 & 3,31 & 5,57 & 75,89 & 0,38 & 0,096 \\
\hline 8 & 141,5 & 24,0 & 2,36 & 3,07 & 5,88 & 70,60 & 0,38 & 0,090 \\
\hline 9 & 165,5 & 25,0 & 2,39 & 2,92 & 5,95 & 69,42 & 0,39 & 0,102 \\
\hline $\begin{array}{l}\text { AMOSTRA } \\
\text { (no) }\end{array}$ & $\begin{array}{c}\text { TEMPO1 } \\
\text { (h) }\end{array}$ & \multicolumn{2}{|c|}{$\begin{array}{c}\text { LEVEDURA } \\
\text { m.s. } \\
\text { (g) }\end{array}$} & $\begin{array}{c}\text { ÁLCOOL } \\
(\mathrm{g} / 100 \mathrm{ml})\end{array}$ & $\begin{array}{l}\text { A.R.T. } \\
\text { (g) }\end{array}$ & \multicolumn{2}{|c|}{$\begin{array}{l}\text { ACIDEZ } \\
\text { TOTAL } \\
\text { (g) }\end{array}$} & $\begin{array}{l}\text { ACIDEZ } \\
\text { VOLÁTIL } \\
\text { (g) }\end{array}$ \\
\hline 1 & 0 & 3,50 & & - & $1.811,10$ & \multicolumn{2}{|c|}{10,50} & - \\
\hline 2 & 4,0 & 4,70 & & 0,07 & $1.786,10$ & \multicolumn{2}{|c|}{12,00} & - \\
\hline 3 & 21,5 & 19,70 & & 1,20 & $1.517,90$ & \multicolumn{2}{|c|}{27,00} & 1,20 \\
\hline 4 & 45,5 & 29,70 & & 2,67 & $1.179,20$ & \multicolumn{2}{|c|}{32,30} & 3,30 \\
\hline 5 & 69,5 & 31,70 & & 3,52 & 989,60 & \multicolumn{2}{|c|}{34,50} & 6,00 \\
\hline 6 & 93.5 & 32,10 & & 4,04 & 826,10 & \multicolumn{2}{|c|}{36,70} & 7,80 \\
\hline 7 & 117,5 & 33,10 & & 4,40 & 758,90 & \multicolumn{2}{|c|}{38,20} & 9,60 \\
\hline 8 & 141,5 & 30,70 & & 4,63 & 706,00 & \multicolumn{2}{|c|}{38,20} & 9,00 \\
\hline 9 & 165,5 & 29,20 & & 4,70 & 694,20 & \multicolumn{2}{|c|}{39,00} & 10,20 \\
\hline
\end{tabular}

\footnotetext{
1 - Tempo de fermentaçảo.
} 
Ainda procurando encontrar um parâmetro satisfatório para concentração inicial de células que fosse capaz de produzir um produto de qualidade e com a maior produtividade possível, foram conduzidas duas fermentações simultâneas, em batelada, com duas linhagens de levedura, ambas Saccharomyces cerevisiae.

Uma foi isolada do fermento prensado comercial Fleishmann e a outra pertence a coleção da Micoteca do Departamento de Ciência e Tecnologia Agroindustrial, com a sigla IZ-888 e já utilizada por produtores de hidromel, segundo dados catalogados no arquivo da Micoteca.

Os objetivos do quarto experimento foram de encontrar a concentração inicial de fermento que possibilitasse a produção de um produto satisfatório e comparar possíveis diferenças de condução provocadas pela diferença de linhagens e, particularmente, por uma linhagem já escolhida pelos produtores de hidromel.

Os resultados obtidos nas duas fermentações estão mostrados nas Tabelas 11 e 12 .

A concentração celular inicial obtida pelo processo descrito para ambas as linhagens foi muito semelhante, de $0,35 \mathrm{~g} / 1$ massa seca para IZ - 888 e 0,29 $\mathrm{g} / 1$ massa seca para isolado de fermento prensado.

A redução de $65 \%$ do inóculo inicial em relação ao terceiro experimento trouxe novamente uma redução não proporcional em relação a produtividade, que entretanto, está prejudicada no cálculo devido a suspensão do experimento após 165 horas. 
A evolução muito lenta dos dados de produção como concentração de álcool, de consumo de açúcares, de crescimento celular e principalmente pela queda de viabilidade celular acentuada em torno do sexto, sétimo e oitavo dias, possivelmente, em função do $\mathrm{pH}$ inferior a 2,4 que pode ter se tornado parcialmente letal, levaram a suspender a continuação do experimento e a repetí-lo para detectar se nenhum outro fator poderia ter influenciado. Lembrando que o teor alcóolico alcançado em ambos os casos foi apenas em torno de $6 \%$ de álcool e que ambas as fermentações tiveram comportamento ou performance similar até então, optou-se por repetir o ensaio. 


\subsubsection{Repetição do quarto experimento em batelada}

\section{Condições experimentais ( $3^{\mathrm{a}}$ fermentação)}

Concentração do mosto em ART $=181,04 \mathrm{~g} / 1$

Volume total do mosto $=10,0$ litros

Inóculo, massa seca $=0,15 \mathrm{~g} / 1$

Levedura $=$ linhagem isolada do fermento prensado

Mel de laranjeira $=2,32 \mathrm{~g} / 1$

Agitação $=100 \mathrm{rpm}$

Ajuste de $\mathrm{pH}=1,5 \mathrm{~g} / 1$ de ácido cítrico

Correção mineral: $1,587 \mathrm{~g} / 1$ de sulfato de amônio

$0,502 \mathrm{~g} / 1$ de fosfato de potássio

$0,185 \mathrm{~g} / 1$ de cloreto de magnésio 
Tabela 13. Resultados da $3 a$ fermentação do 40 experimento em batelada, pela linhagem de levedura isolada do fermento prensado.

\begin{tabular}{|c|c|c|c|c|c|c|c|c|}
\hline $\begin{array}{l}\text { AMOSTRA } \\
\text { (no) }\end{array}$ & $\begin{array}{l}\text { TEMPO }{ }^{1} \\
\text { (h) }\end{array}$ & $\begin{array}{c}\text { TEMPERAT. } \\
\left({ }^{\circ} \mathrm{C}\right)\end{array}$ & $\mathrm{pH}$ & $\begin{array}{c}\text { LEVEDURA } \\
\text { m.s. } \\
(g / l)\end{array}$ & $\begin{array}{r}\text { ÁLCOOL } \\
(\mathrm{ml} / 100 \mathrm{ml})\end{array}$ & $\begin{array}{l}\text { A.R.T } \\
(g / l)\end{array}$ & $\begin{array}{c}\text { ACIDEZ } \\
\text { TOTAL } \\
\text { (g/100ml) }\end{array}$ & $\begin{array}{c}\text { ACIDEZ } \\
\text { VOLÁTIL } \\
(g / 100 \mathrm{ml})\end{array}$ \\
\hline 1 & 0 & 26,0 & 3,77 & 0,15 & - & 181,04 & 0,07 & * \\
\hline 2 & 5,5 & 26,0 & 3,70 & 0,33 & 0,16 & 180,53 & 0,09 & 0,002 \\
\hline 3 & 24,0 & 25,0 & 2,42 & 1,29 & 1,24 & 165,16 & 0,22 & 0,011 \\
\hline 4 & 48,0 & 25,0 & 2,41 & 1,54 & 2,27 & 141,05 & 0,27 & 0,026 \\
\hline 5 & 72,0 & 23,5 & 2,41 & 1,54 & 3.03 & 130,12 & 0,29 & 0,040 \\
\hline 6 & 96,0 & 23,5 & 2,41 & 1,69 & 3,46 & 118,17 & 0,27 & 0,046 \\
\hline 7 & 123,0 & 23,5 & 2,37 & 1,75 & 3,95 & 106,86 & 0,32 & 0,052 \\
\hline 8 & 144,5 & 24,0 & 2,47 & 1,67 & 4,25 & 105,39 & 0,30 & 0,055 \\
\hline 9 & 167,0 & 24,5 & 2,45 & 1,78 & 4,39 & 103,37 & 0,30 & 0,058 \\
\hline 10 & 215,0 & 25,0 & 2,51 & 1,80 & 4,54 & 98,35 & 0,30 & 0,058 \\
\hline 11 & 264,5 & 24,0 & 2,33 & 1,65 & 4,54 & 95,14 & 0,32 & 0,063 \\
\hline 12 & 310,0 & 24,0 & 2,28 & 1,88 & 4,90 & 91,56 & 0,34 & 0,063 \\
\hline 13 & 363,5 & 23,5 & 2,30 & 1,98 & 5,72 & 79,51 & 0,34 & 0,063 \\
\hline 14 & 410,5 & 24,5 & 2,28 & 2,12 & 6,64 & 63,78 & 0,33 & 0,058 \\
\hline 15 & 435,0 & 24,5 & 2,28 & 2,10 & 7,04 & 55,85 & 0,33 & 0,058 \\
\hline 16 & 485,5 & 26,0 & 2,27 & 2,29 & 7,43 & 47,58 & 0,33 & 0,055 \\
\hline 17 & 531,5 & 26,0 & 2,26 & 2,49 & 7,43 & 47,58 & 0,33 & 0,055 \\
\hline
\end{tabular}

\section{AMOSTRA}

(no)

\section{TEMPO1}

(h)

\section{LEVEDURA}

m.s.

(g)

\section{ÁLCOOL}

(g/100ml)

1,50

3,30

12,90

15,40

15,40

16,90

17,50

16,70

17,80

18,00

16,50

18,80

19,80

21,20

21,00

22,90

24,90

0,12
0,98
1,79
2,40
2,73
3.13
3.35
3,46
3.58
3,58
3,87
4,51
5,24
5,55
5,87
5,87

A.R.T.

(g)
ACIDEZ

TOTAL

(g)
ACIDEZ

VOLÁTIL

(g)

$\begin{array}{rrc}1.810,40 & 7,0 & - \\ 1.805,30 & 9,0 & 0,20 \\ 1.651,60 & 22,0 & 1,10 \\ 1.410,50 & 27,0 & 2,60 \\ 1.301,20 & 29,0 & 4,00 \\ 1.181,70 & 27,0 & 4,60 \\ 1.068,60 & 32,0 & 5,20 \\ 1.053,90 & 30,0 & 5,50 \\ 1.033,70 & 30,0 & 5,80 \\ 983,50 & 30,0 & 5,80 \\ 951,40 & 32,0 & 6,30 \\ 915,60 & 34,0 & 6,30 \\ 795,10 & 34,0 & 6,30 \\ 637,80 & 33,0 & 5,80 \\ 558,50 & 33,0 & 5,80 \\ 475,80 & 33,0 & 5,50 \\ 475,80 & 33,0 & 5,50\end{array}$

\footnotetext{
1 - Tempo de fermentação.
} 


\section{Condições experimentais ( $4^{2}$ fermentação)}

Concentração do mosto em ART $=199,23 \mathrm{~g} / 1$

Volume total do mosto $=10,0$ litros

Inóculo, massa seca $=0,21 \mathrm{~g} / 1$

Levedura $=S$. cerevisiae $(\mathrm{IZ}-888)$

Mel de laranjeira $=2,32 \mathrm{Kg}$

Agitação $=100 \mathrm{rpm}$

Ajuste de $\mathrm{pH}=1,5 \mathrm{~g} / 1$ de ácido cítrico

Correção mineral: 1,587 g/l de sulfato de amônio

$0,502 \mathrm{~g} / 1$ de fosfato de potássio

$0,185 \mathrm{~g} / 1$ de cloreto de magnésio 
Tabela 14. Resultados da 4a fermentação do 40 experimento em batelada, pela linhagem de levedura S. cerevisiae (1Z-888).

\begin{tabular}{|c|c|c|c|c|c|c|c|c|}
\hline $\begin{array}{l}\text { AMOSTRA } \\
\text { (no) }\end{array}$ & $\begin{array}{c}\text { TEMPO } 1 \\
\text { (h) }\end{array}$ & $\begin{array}{c}\text { TEMPERAT. } \\
\text { ('०) }\end{array}$ & $\mathrm{pH}$ & $\begin{array}{c}\text { LEVEDURA } \\
\text { m.s. } \\
(\mathrm{g} / 1)\end{array}$ & $\begin{array}{l}\text { ÁLCOOL } \\
(\mathrm{ml} / 100 \mathrm{ml})\end{array}$ & $\begin{array}{r}\text { A.R.T } \\
(g / l)\end{array}$ & $\begin{array}{l}\text { ACIDEZ } \\
\text { TOTAL } \\
\text { (g/100ml) }\end{array}$ & $\begin{array}{l}\text { ACIDEZ } \\
\text { VOLÁTIL } \\
(\mathrm{g} / 100 \mathrm{ml})\end{array}$ \\
\hline 1 & 0 & 26,0 & 3,79 & 0,21 & * & 199,23 & 0,07 & - \\
\hline 2 & 5,3 & 27,0 & 3,82 & 0,29 & 0,09 & 193,73 & 0,09 & 0,002 \\
\hline 3 & 24,0 & 26,0 & 2,44 & 1,51 & 1,10 & 170,70 & 0,23 & 0,009 \\
\hline 4 & 48,0 & 26,0 & 2,39 & 2,34 & 2,33 & 152,23 & 0,27 & 0,023 \\
\hline 5 & 72,0 & 24,5 & 2,35 & 1,61 & 3.03 & 138,75 & 0,33 & 0,050 \\
\hline 6 & 96,0 & 22,5 & 2,36 & 2,39 & 3,46 & 131,47 & 0,29 & 0,063 \\
\hline 7 & 123,0 & 24,0 & 2,32 & 2,38 & 3,81 & 121,66 & 0,31 & 0,083 \\
\hline 8 & 144,5 & 23,5 & 2,40 & 2,20 & 3,88 & 121,33 & 0,31 & 0,086 \\
\hline 9 & 167,0 & 25,0 & 2,37 & 2,28 & 4,17 & 121,33 & 0,33 & 0,086 \\
\hline 10 & 215,0 & 25,0 & 2,38 & 2,69 & 4,97 & 103,30 & 0,34 & 0,086 \\
\hline 11 & 264,5 & 24,0 & 2,19 & 2,58 & 6,18 & 81,19 & 0,32 & 0,080 \\
\hline 12 & 310,0 & 24,0 & 2,18 & 2,81 & 7,35 & 64,51 & 0,34 & 0,080 \\
\hline 13 & 363,5 & 24,0 & 2,24 & 2,80 & 7,59 & 53,97 & 0,32 & 0,072 \\
\hline 14 & 410,5 & 25,5 & 2,26 & 2,81 & 7,59 & 55,64 & 0,32 & 0,072 \\
\hline 15 & 435,0 & 25,5 & 2,26 & 2,77 & 7,59 & 55,30 & 0,32 & 0,072 \\
\hline
\end{tabular}

\begin{tabular}{cc}
\hline AMOSTRA & TEM \\
$(\mathrm{n} \cong)$ & $(\mathrm{h})$
\end{tabular}

(h)

\section{LEVEDURA \\ m.s.}

(g)

\section{ÁLCOOL}

(g/100mI)

\section{A.R.T.}

(g)

ACIDEZ ACIDEZ

\begin{tabular}{|c|c|c|c|c|c|c|}
\hline 1 & 0 & 2,10 & - & $1.992,30$ & 7,0 & - \\
\hline 2 & 5,3 & 2,90 & 0,07 & $1.937,60$ & 9,0 & 0,20 \\
\hline 3 & 24,0 & 15,10 & 0,87 & $1.707,00$ & 23,0 & 0,90 \\
\hline 4 & 48,0 & 23,40 & 1,84 & $1.522,30$ & 27,0 & 2,30 \\
\hline 5 & 72,0 & 16,10 & 2,40 & $1.387,50$ & 33,0 & 5,00 \\
\hline 6 & 96,0 & 23,80 & 2,73 & $1.314,70$ & 29,0 & 6,30 \\
\hline 7 & 123,0 & 23,80 & 3,01 & $1.216,60$ & 31,0 & 8,30 \\
\hline 8 & 144,5 & 22,00 & 3,07 & $1.213,30$ & 31,0 & 8,60 \\
\hline 9 & 167,0 & 22,80 & 3,29 & $1.213,30$ & 33,0 & 8,60 \\
\hline 10 & 215,0 & 26,90 & 3,92 & $1.033,00$ & 34,0 & 8,60 \\
\hline 11 & 264,5 & 25,80 & 4,88 & 811,90 & 32,0 & 8,00 \\
\hline 12 & 310,0 & 28,10 & 5,80 & 645,10 & 34,0 & 8,00 \\
\hline 13 & 363,5 & 28,00 & 6,00 & 539,70 & 32,0 & 7,20 \\
\hline 14 & 410,5 & 28,10 & 6,00 & 556,40 & 32,0 & 7,20 \\
\hline 15 & 435,0 & 27,70 & 6,00 & 553,00 & 32,0 & 7,20 \\
\hline
\end{tabular}

\footnotetext{
1 - Tempo de fermentação.
} 


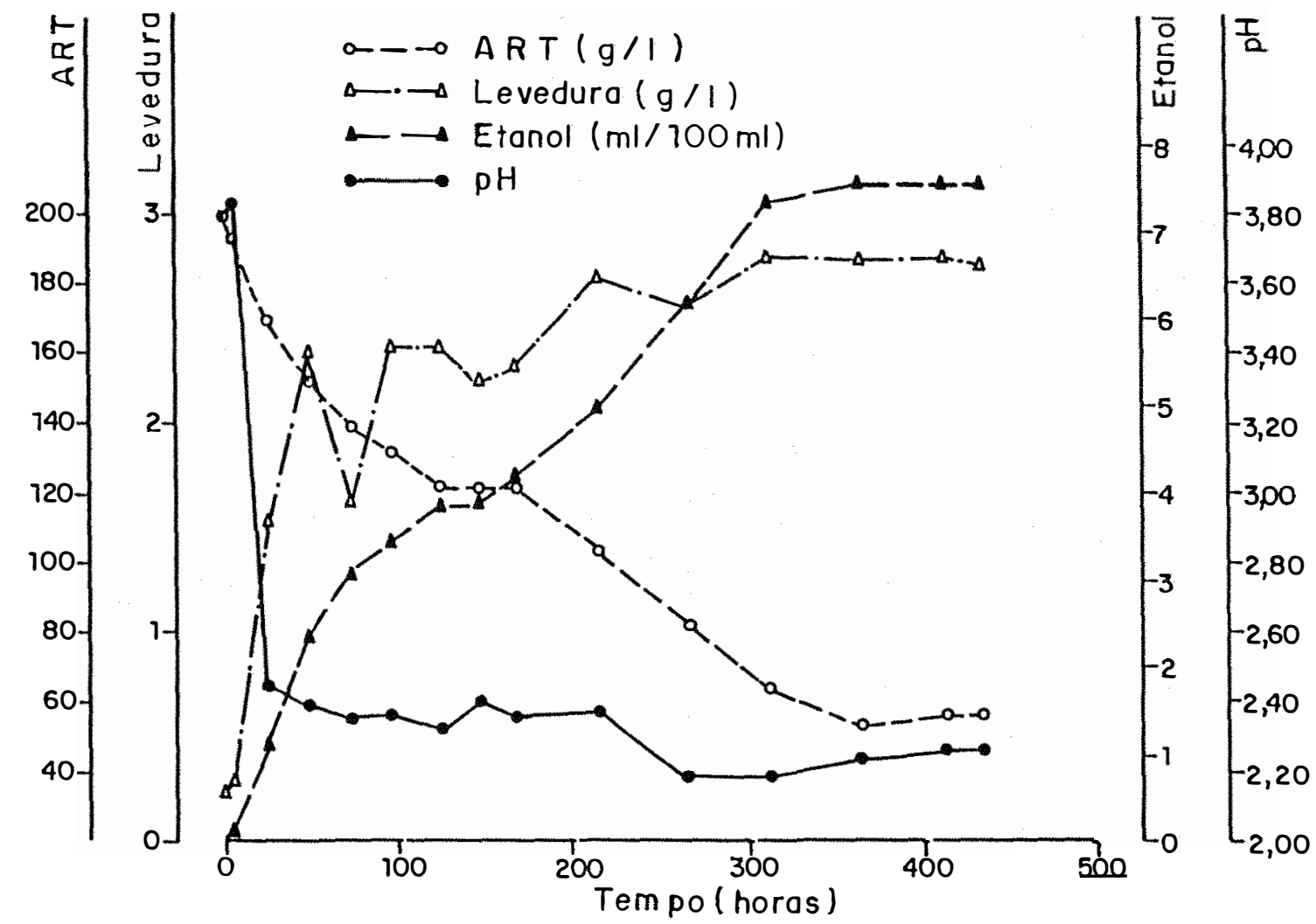

Figura 8-Açucares redutores totais, massa celular, etanol e pH para a 49 fermentaçāo do 4 ㅇ experimento em batelada.

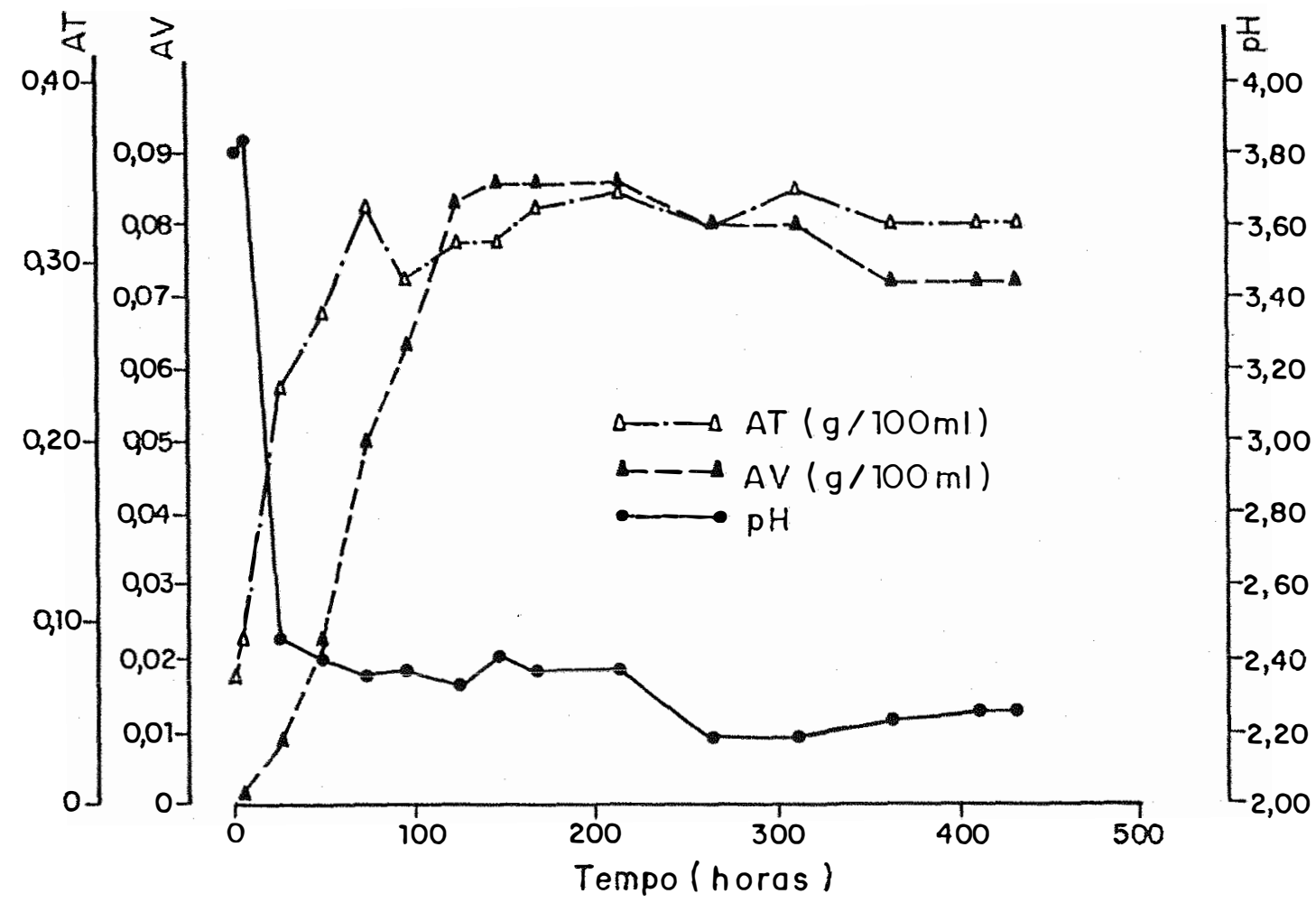

Figura 9-Ácidos totais (AT), ácidos voláteis (AV) e pH para a 4? fermen toçāo do 4 ㅇ experimento em batelada. 
Como já foi especificado, as condições experimentais descritas em 4.3.1.4. foram repetidas e também o desenvolvimento do inóculo de ambas as linhagens. O ensaio repetição foi acompanhado por 22 dias e considerou-se terminado quando houve paralisação ou estabilização dos parâmetros de produção, cessando o consumo de açúcares em cada um dos ensaios que constituiram o experimento.

Como pode ser observado à Tabela 13, correspondente ao ensaio com linhagem isolada de fermento prensado e Tabela 14 e Figuras 8 e 9, correspondente ao ensaio com Saccharomyces cerevisiae 12-888, o comportamento metabólico das linhagens são muito semelhantes e seguem os mesmos padrões e valores, terminando após 22 dias com açúcares residuais da ordem de 50,0 g/1 o que daria um vinho tipo suave ou doce, dependendo da concentração inicial. É o que tende a acontecer aos vinhos naturais com fermentação não conduzida para total consumo dos açúcares até a obtenção de um tipo seco que poderia ser posteriormente manipulados até a obtenção de outro tipo, suave ou doce pela adição de mel.

A queda de $\mathrm{pH}$ até cerca de 2,20 é acompanhada pela perda de viabilidade que é crescente ao longo do tempo, justificando assim a parada da fermentação pela redução da população ativa.

Cada partida de mel com pouco maior ou menor riqueza de sais e material protéico faz então variar o tempo e o ponto onde termina a fermentação, dando vinhos variáveis em açúcares residuais, tirando a possibilidade de um melhor controle de qualidade e influindo ainda nos testes de percepção de sabor e aroma. 
De antemão conhecia-se que o teste de sabor e aroma daria um resultado diferente dos demais até então, devido a sobra considerável de açúcares residuais. De fato, um dos pontos principais de observação dos testadores foi quanto ao tipo doce ou suave, muito mais agradável a maioria que não foi selecionada nem treinada para os testes em referência.

Foi considerado ainda que o aroma a fermento ficou muito atenuado e o sabor e odor a mel ficaram mais acentuados. Dessa forma tomou-se como correta a concentração de células iniciais obtidas no quarto experimento.

\subsubsection{Escolha do tamponante ou corretivo da acidez.}

Uma vez que os ácidos orgânicos produzidos na fermentação são suficientes para abaixar pH até um nível drástico capaz de influir na viabilidade, há a necessidade de um controle desse fator ou correção para que o crescimento populacional e a produção de etanol não sejam afetadas.

Para tal pode ser adicionado um hidróxido como o hidróxido de sódio, um tamponante, como os tampões fosfato, citrato-fosfato e outros (MORSE, 1971). Para condução da fermentação com tamponantes, procedeu-se uma série de ensaios. 


\subsubsection{Quinto experimento em batelada}

Condições experimentais ( $1^{a}$ fermentação)

Concentração do mosto em ART $=179,79 \mathrm{~g} / 1$

Volume total do mosto $=10,0$ litros

Inóculo, massa seca $=0,23 \mathrm{~g} / 1$

Levedura $=$ linhagem isolada do fermento prensado

Mel de laranjeira $=2,3 \mathrm{Kg}$

Agitação $=100 \mathrm{rpm}$

Ajuste de $\mathrm{pH}$ do mosto $=40 \mathrm{~g}$ de ácido cítrico $+50 \mathrm{ml}$ de $\mathrm{KOH} 5 \mathrm{~N}$

Controle de $\mathrm{pH}$ durante a fermentação $=\mathrm{KOH} 5 \mathrm{~N}$

Correção mineral: $1,587 \mathrm{~g} / 1$ de sulfato de amônio

$0,502 \mathrm{~g} / 1$ de fosfato de potássio

$0,185 \mathrm{~g} / 1$ de cloreto de magnésio 


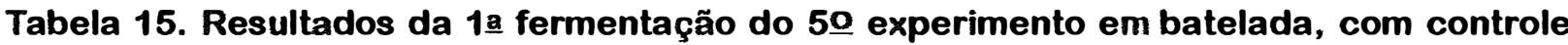
de pH com KOH $5 \mathrm{~N}$, pela linhagem de levedura isolada do fermento prensado.

\begin{tabular}{|c|c|c|c|c|c|c|c|c|c|c|}
\hline $\begin{array}{l}\text { AMOSTRA } \\
\text { (no) }\end{array}$ & $\begin{array}{l}\text { TEMPO1 } \\
\text { (h) }\end{array}$ & $\begin{array}{c}\text { TEMPERAT. } \\
\left({ }^{\circ} \mathrm{C}\right)\end{array}$ & $\mathrm{pH}^{2}$ & $\begin{array}{l}\text { KOH } \\
5 \mathrm{~N} \\
(\mathrm{ml})\end{array}$ & $\mathrm{pH}^{3}$ & $\begin{array}{l}\text { LEVEDURA } \\
\text { m.s. } \\
\text { (gil) }\end{array}$ & $\begin{array}{c}\text { ÁLCOOL } \\
\text { (ml/100ml) }\end{array}$ & $\begin{array}{rr}\text { A.R.T } & A \\
(g / 1) & T \\
& (g)\end{array}$ & $\begin{array}{l}\text { ACIDEZ } \\
\text { TOTAL } \\
\text { (100ml) }\end{array}$ & $\begin{array}{l}\text { ACIDEZ } \\
\text { VOLÁTIL } \\
\text { (g/100ml) }\end{array}$ \\
\hline 1 & 0 & 27,0 & 4,00 & - & - & 0,23 & $=$ & 179,79 & 0,32 & - \\
\hline 2 & 3,0 & 26,0 & 3,98 & - & - & 0,32 & 0,09 & 181,30 & 0,32 & - \\
\hline 3 & 21,5 & 25,0 & 2,96 & 20 & 3,52 & 1,84 & 1,30 & 156,30 & 0,44 & 0,002 \\
\hline 4 & 45,0 & 25,0 & 2,75 & 25 & 3,31 & 5,69 & 3,95 & 112,06 & 0,58 & 0,003 \\
\hline 5 & 68,0 & 25,0 & 3,31 & - & - & 7,49 & 6,49 & 63,65 & 0,61 & 0,006 \\
\hline 6 & 92,0 & 23,5 & 3,38 & - & - & 6,21 & 8,64 & 32,73 & 0,69 & 0,006 \\
\hline 7 & 117,0 & 23,0 & 3,41 & - & - & 6,62 & 9,88 & 11,75 & 0,58 & 0,006 \\
\hline 8 & 138,0 & 25,0 & 3,36 & - & - & 6,64 & 9,96 & 10,54 & 0,58 & 0,006 \\
\hline $\begin{array}{l}\text { AMOSTRA } \\
\text { (no) }\end{array}$ & $\begin{array}{c}\text { TEMPO' } \\
\text { (h) }\end{array}$ & & $\begin{array}{c}\text { EVEDURA } \\
\text { m.s. } \\
(\mathrm{g})\end{array}$ & 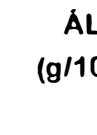 & $\begin{array}{l}\text { COOL } \\
0 \mathrm{ml})\end{array}$ & $\begin{array}{r}\text { A.R. } \\
\text { (g) }\end{array}$ & & $\begin{array}{c}\text { ACIDE } \\
\text { TOTAL } \\
\text { (g) }\end{array}$ & & $\begin{array}{c}\text { ACIDEZ } \\
\text { VOLÁTIL } \\
\text { (g) }\end{array}$ \\
\hline 1 & 0 & & 2,30 & - & & 1.797, &, 90 & 32,0 & & - \\
\hline 2 & 3,0 & & 3,20 & 0, & & 1.813, &, 00 & 32,0 & & - \\
\hline 3 & 21,5 & & 18,40 & 1, & & 1.563, &, 00 & 44,0 & & 0,2 \\
\hline 4 & 45,0 & & 56,90 & 3 & & 1.120 , &, 60 & 58,0 & & 0,3 \\
\hline 5 & 68,0 & & 74,90 & 5 & & 636 &, 50 & 61,0 & & 0,6 \\
\hline 6 & 92,0 & & 62,10 & 6 , & & 327 & ,30 & 69,0 & & 0,6 \\
\hline 7 & 117,0 & & 66,20 & 7 & & 117 &, 50 & 58,0 & & 0,6 \\
\hline 8 & 138,0 & & 66,40 & 7 & 87 & 105 & 5,40 & 58,0 & & 0,6 \\
\hline
\end{tabular}


Condições experimentais ( $2^{2}$ fermentação)

Concentração do mosto em ART $=185,39 \mathrm{~g} / 1$

Volume total do mosto $=10,0$ litros

Inóculo, massa seca $=0,23 \mathrm{~g} / 1$

Levedura $=S$. cerevisiae $(\mathrm{IZ}-888)$

Mel de laranjeira $=2,3 \mathrm{Kg}$

Agitação $=100 \mathrm{rpm}$

Ajuste de $\mathrm{pH}$ do mosto $=40 \mathrm{~g}$ de ácido cítrico $+50 \mathrm{ml}$ de $\mathrm{KOH} 5 \mathrm{~N}$

Controle de $\mathrm{pH}$ durante a fermentação $=\mathrm{KOH} 5 \mathrm{~N}$

Correção mineral: 1,587 g/l de sulfato de amônio

$0,502 \mathrm{~g} / 1$ de fosfato de potássio

$0,185 \mathrm{~g} / 1$ de cloreto de magnésio 
Tabela 16. Resultados da 2a fermentação do 50 experimento em batelada, com controle de pH com KOH $5 \mathrm{~N}$, por S. cerevisiae $(1 \mathrm{Z}-888)$.

\begin{tabular}{|c|c|c|c|c|c|c|c|c|c|c|}
\hline $\begin{array}{l}\text { AMOSTRA } \\
\text { (no) }\end{array}$ & $\begin{array}{c}\text { TEMPO } \\
\text { (h) }\end{array}$ & $\begin{array}{l}1 \text { TEMPERAT. } \\
\left({ }^{\circ} \mathrm{C}\right)\end{array}$ & $\mathrm{pH}^{2}$ & $\begin{array}{c}\mathrm{KOH} \\
5 \mathrm{~N} \\
(\mathrm{ml})\end{array}$ & $\mathrm{pH}^{3}$ & $\begin{array}{l}\text { LEVEDURA } \\
\text { m.s. } \\
(g / l)\end{array}$ & $\begin{array}{l}\text { ÁLCOOL } \\
\text { (ml/100ml) }\end{array}$ & $\begin{array}{c}\text { A.R.T } \\
(g / 1)\end{array}$ & $\begin{array}{l}\text { ACIDEZ } \\
\text { TOTAL } \\
\text { (g/100ml) }\end{array}$ & $\begin{array}{l}\text { ACIDEZ } \\
\text { VOLÁTIL } \\
(\mathrm{g} / 100 \mathrm{ml})\end{array}$ \\
\hline 1 & 0 & 28,0 & 4,01 & - & - & 0,23 & - & 185,39 & 0,32 & - \\
\hline 2 & 3,0 & 27,0 & 3,98 & - & - & 0,32 & 0,09 & 176,34 & 0,37 & 0,002 \\
\hline 3 & 21,5 & 26,0 & 3,03 & 20 & 3,56 & 1,75 & 1,37 & 157,78 & 0,44 & 0,003 \\
\hline 4 & 45,0 & 26,0 & 2,96 & 20 & 3,46 & 4,40 & 4,83 & 95,01 & 0,53 & 0,011 \\
\hline 5 & 68,0 & 26,0 & 3,50 & . & - & 6,53 & 8,16 & 43,30 & 0,56 & 0,011 \\
\hline 6 & 92,0 & 24,0 & 3,54 & - & - & 6,32 & - & 11,55 & 0,56 & 0,011 \\
\hline 7 & 98,0 & - & - & - & - & - & 9,96 & - & - & - \\
\hline 8 & 117,0 & 24,0 & 3,55 & - & - & 6,26 & 9,96 & 11,27 & 0,51 & 0,007 \\
\hline $\begin{array}{l}\text { AMOSTRA } \\
\text { (nㅇ) }\end{array}$ & & $\begin{array}{l}\text { TEMPO1 } \\
\text { (h) }\end{array}$ & & $\begin{array}{c}\text { LEVEDU } \\
\text { m.s. } \\
\text { (g) }\end{array}$ & & $\begin{array}{l}\text { ÁLCOOL } \\
(g / 100 \mathrm{ml})\end{array}$ & $\begin{array}{l}\text { A.R.T. } \\
\text { (g) }\end{array}$ & $\begin{array}{c}\text { ACIDEZ } \\
\text { TOTAL } \\
\text { (g) }\end{array}$ & & $\begin{array}{c}\text { ACIDEZ } \\
\text { VOLÁTIL } \\
\text { (g) }\end{array}$ \\
\hline 1 & & 0 & & 2,30 & & - & $1.853,90$ & 32,0 & & - \\
\hline 2 & & 3,0 & & 3,20 & & 0,07 & $1.763,40$ & 37,0 & & 0,20 \\
\hline 3 & & 21,5 & & 17,50 & & 1,09 & $1.577,80$ & 44,0 & & 0,30 \\
\hline 4 & & 45,0 & & 44,00 & & 3,81 & 950,10 & 53,0 & & 1,10 \\
\hline 5 & & 68,0 & & 65,30 & & 6,44 & 433,00 & 56,0 & & 1,10 \\
\hline 6 & & 92,0 & & 63,20 & & - & 115,50 & 56,0 & & 1,10 \\
\hline 7 & & 98,0 & & - & & 7,87 & - & - & & - \\
\hline 8 & & 117,0 & & 62,60 & & 7,87 & 112,70 & 51,0 & & 0,70 \\
\hline
\end{tabular}

' - Tempo de fermentação.

2- Antes da correção.

3 - Após adição de KOH $5 \mathrm{~N}$ 


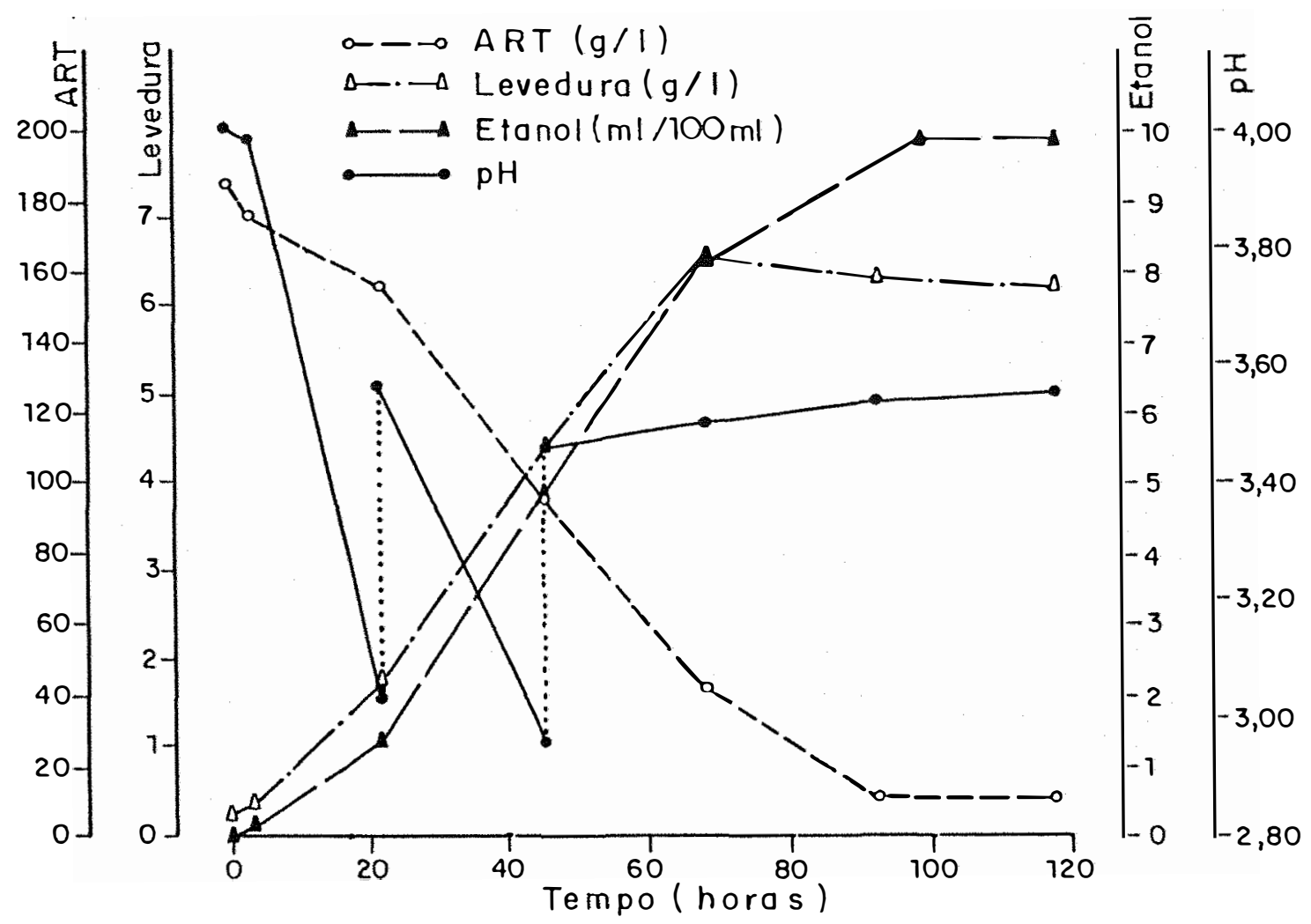

Figura 10 - Acúcares redutores totais, massa celular, etanol e pH para a 2a fermentaçāo do 5o experimento em batelada.

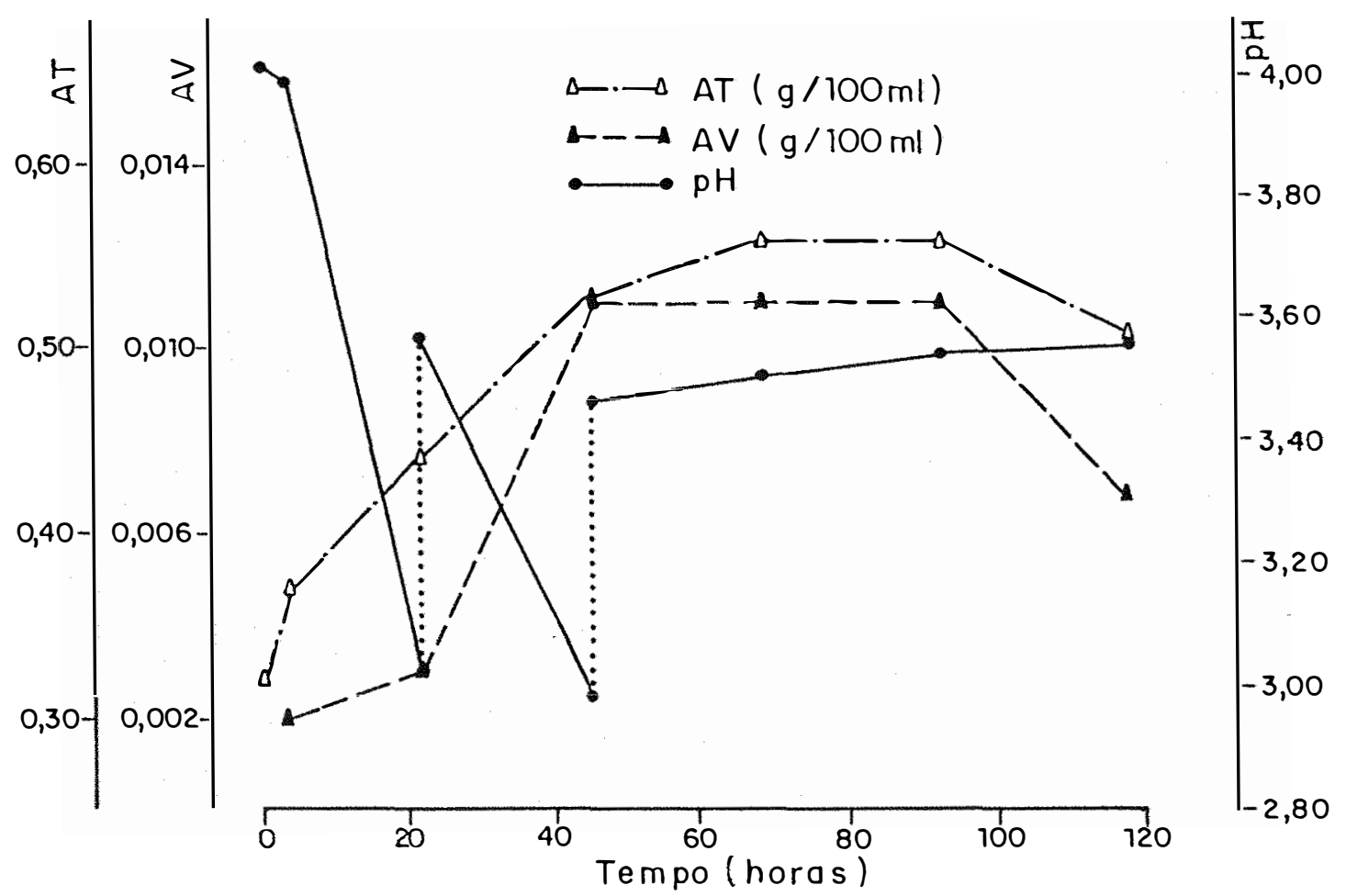

Figura 11-Ácidos totais (AT), ácidos voláteis (AV) e pH para a 2 a fermentaçāo do 5을 experimento em batelada. 
O quinto experimento constituiu-se em dois ensaios de fermentação com os dois microrganismos utilizados no quarto experimento. As condições experimentais foram similares aos anteriormente descritos e como particularidade, apenas o acréscimo de maior suplementação em ácido círico (4,0g/litro) até cerca de pH 2,5 e hidróxido de potássio $5 \mathrm{~N}(50 \mathrm{ml})$, que trouxe o $\mathrm{pH}$ final em torno de 4,0 , produzindo o tampão citrato (ácido cítrico mais citrato de potássio) e citrato-fosfato com o fosfato dibásico de potássio usado como fonte suplementar de fósforo principalmente.

A preocupação de manter elevada a viabilidade celular durante a condução do processo tornou necessária a adição intermitente ou periódica de hidróxido de potássio $(5 \mathrm{~N})$ quando os valores de $\mathrm{pH}$ caiam para valores inferiores a 3.0. A correção era feita com valores mínimos necessários para elevação até pH 3,3-3,5.

Com isso foi conseguido uma fermentação onde o inóculo tinha um nível de viabilidade de $92,7 \%$ e que se apresentou com $93,2 \%$ no primeiro dia de fermentação, $98,8 \%$ no segundo dia, $98,2 \%$ no terceiro dia, $97,9 \%$ no quinto dia. O outro ensaio com isolado do fermento prensado apresentou idêntica tendência, variando de $82 \%$ no inóculo a $97 \%, 95,8 \%, 96 \%$ e $94,8 \%$ no decorrer dos dias, respectivamente. Assim, a correção de pH foi a grande chave para obter ganho de massa celular, viabilidade e produtividade.

Esses resultados analíticos e de condução estão mostrados nas Tabelas 15 e 16 e Figuras 10 e 11.

As fermentações foram acompanhadas até que se repetissem em duas amostras subseqüentes, leituras ou resultados analíticos da concentração de etanol e de 
açúcares residuais considerados como praticamente terminados ou estabilizados e o vinho considerado do tipo seco.

Devido ao efeito tamponante e das correções de $\mathrm{pH}$ durante o processo, os parâmetros da fermentação como as concentrações iniciais e finais de fermento apresentam-se da mesma ordem da alcançada por ROSINI (1986), ou seja 0,32g/l e 7,60 g/1 e $0,23 g / 1$ e 7,49 g/1 no presente estudo. A produção de novas células atingiu até $97 \%$ e a produtividade volumétrica variou de 0,72 a $1,02 \mathrm{ml} \cdot \mathrm{I}^{-1} \cdot \mathrm{h}^{-1}$, terminando a fase fermentativa em 4 a 6 dias, no máximo.

As análises químicas de controle dos parâmetros de padrão de qualidade ou identidade, ainda que ao fim da fase de fermentação, mostraram a acidez total, fixa e volátil muitas vezes dentro dos padrões exigidos pelo SIPV e outras abaixo, o que é facilmente corrigido e permitido por lei. Os testes organolépticos tentativos fizeram uma indicação de que os vinhos se apresentaram com ligeiro sabor e aroma a mel embora ainda lembrasse algo a fermento, principalmente o aroma. É possível que matérias primas de fraco odor, quando fermentadas guardem sempre uma relação de aroma a fermento, devido ao "limiar organoléptico" ou o "poder aromático" dos componentes (BERNARD, 1985) do fermento serem superiores aos componentes aromáticos do mel dilú́do. Talvez devido a esses fatores tenha se desenvolvido bebidas fermentadas de mel e sucos de frutas como sucos círicos (citromel) e outros sucos (de 25 a $50 \%$ ) que fornecem melhor flavor, corpo e buquê num período mais curto de tempo, segundo MORSE (1953b). 
Voltando novamente a apreciação dos nossos "provadores", todos consideraram os vinhos muito pouco ácidos e nenhuma distinção pode ser feita entre os produtos das fermentações conduzidas pelas linhagens de Saccharomyces cerevisiae (IZ-888) e da isolada do fermento prensado comercial "Fleishmann".

\subsubsection{Sexto experimento em batelada}

\section{Condições experimentais ( $1^{2}$ fermentação)}

Concentração do mosto em ART $=174,81 \mathrm{~g} / 1$

Volume total do mosto $=10,0$ litros

Inóculo, massa seca $=0,25 \mathrm{~g} / 1$

Levedura $=$ linhagem isolada do fermento prensado

Mel de laranjeira $=2,3 \mathrm{Kg}$

Agitação $=100$ rpm

Ajuste de $\mathrm{pH}$ do mosto $=1,5 \mathrm{~g} / 1$ de ácido cítrico $+0,75 \mathrm{~g} / 1$ de fosfato de potássio

Correção de pH durante a fermentação $=\mathrm{KOH} 5 \mathrm{~N}$

Correção mineral: $1,587 \mathrm{~g} / 1$ de sulfato de amônio

$$
0,185 \mathrm{~g} / 1 \text { de cloreto de magnésio }
$$


Tabela 17. Resultados da 1a fermentação do 60 experimento em batelada, com controle de $\mathrm{pH}$ com KOH $5 \mathrm{~N}$, pela linhagem de levedura isolada do fermento prensado.

\begin{tabular}{|c|c|c|c|c|c|c|c|c|c|c|}
\hline $\begin{array}{l}\text { AMOSTRA } \\
\text { (no) }\end{array}$ & $\begin{array}{l}\text { TEMPO1 } \\
\text { (h) }\end{array}$ & $\begin{array}{l}\text { TEMPERAT. } \\
\left({ }^{\circ} \mathrm{C}\right)\end{array}$ & $\mathrm{pH}^{2}$ & $\begin{array}{c}\mathrm{KOH} \\
5 \mathrm{~N} \\
(\mathrm{ml})\end{array}$ & $\mathrm{pH}^{3}$ & $\begin{array}{l}\text { LEVEDURA } \\
\text { m.s. } \\
(\mathrm{g} / \mathrm{l})\end{array}$ & $\begin{array}{c}\text { ÁLCOOL } \\
(\mathrm{ml} / 100 \mathrm{ml})\end{array}$ & $\begin{array}{l}\text { A.R.T } \\
\text { (g/l) }\end{array}$ & $\begin{array}{c}\text { ACIDEZ } \\
\text { TOTAL } \\
(g / 100 \mathrm{ml})\end{array}$ & $\begin{array}{l}\text { ACIDEZ } \\
\text { VOLÁTIL } \\
(\mathrm{g} / 100 \mathrm{ml})\end{array}$ \\
\hline 1 & 0 & 24,5 & 4,06 & - & - & 0,25 & - & 174,81 & 0,20 & - \\
\hline 2 & 6,0 & 26,0 & 3,75 & 8 & 3,90 & 0,44 & 0,22 & 174,87 & 0,21 & - \\
\hline 3 & 28,0 & 24,5 & 2,69 & 35 & 4,25 & 1,62 & 1,72 & 144,68 & 0,30 & 0,002 \\
\hline 4 & 52,5 & 24,0 & 3,00 & 23 & 3,80 & 3,10 & 4,46 & 98,67 & 0,30 & 0,011 \\
\hline 5 & 72,0 & 23,0 & 3,66 & - & - & 3,62 & 6,33 & 61,51 & 0,30 & 0,011 \\
\hline 6 & 95,5 & 22,5 & 3,69 & - & - & 3,22 & 7,91 & 39,70 & 0,34 & 0,004 \\
\hline 7 & 119,5 & 22,5 & 3,70 & - & - & 2,86 & 8,89 & 22,21 & 0,37 & 0,009 \\
\hline 8 & 142,0 & 22,0 & 3,71 & - & - & 6,30 & 9,63 & 15,08 & 0,33 & 0,009 \\
\hline 9 & 173,0 & 25,0 & 3,74 & - & - & 6,53 & 9,96 & 9,25 & 0,33 & 0,011 \\
\hline 10 & 176,0 & - & - & - & - & - & 9,96 & - & - & - \\
\hline
\end{tabular}

\begin{tabular}{ccccccc}
\hline AMOSTRA & TEMPO1 & LEVEDURA & ÁLCOOL & A.R.T. & ACIDEZ & ACIDEZ \\
$($ no $)$ & (h) & m.s. & $(g / 100 \mathrm{ml})$ & (g) & TOTAL & VOLÁTIL
\end{tabular}

(g)

(g)

(g)

\begin{tabular}{|c|c|c|c|c|c|c|}
\hline 1 & 0 & 2,50 & - & $1.744,10$ & 20,0 & - \\
\hline 2 & 6,0 & 4,40 & 0,18 & $1.748,70$ & 21,0 & - \\
\hline 3 & 28,0 & 16,20 & 1,35 & $1.446,80$ & 30,0 & 0,20 \\
\hline 4 & 52,5 & 31,00 & 3,52 & 986,70 & 30,0 & 1,10 \\
\hline 5 & 72,0 & 36,20 & 5,00 & 615,10 & 30,0 & 1,10 \\
\hline 6 & 95,5 & 32,20 & 6,25 & 397,00 & 34,0 & 0,40 \\
\hline 7 & 119,5 & 28,60 & 7,01 & 222,10 & 37,0 & 0,90 \\
\hline 8 & 142,0 & 63,00 & 7,61 & 150,80 & 33,0 & 0,90 \\
\hline 9 & 173,0 & 65,30 & 7,87 & 92,00 & 33,0 & 1,10 \\
\hline 10 & 176,0 & - & 7,87 & - & * & - \\
\hline
\end{tabular}

' - Tempo de fermentação.

2- Antes da correção.

3 - Após adiçåo de KOH $5 \mathrm{~N}$ 
Condições experimentais ( $2^{a}$ fermentação)

Concentração do mosto em ART $=172,94 \mathrm{~g} / 1$

Volume total do mosto $=10,0$ litros

Inóculo, massa seca $=0,25 \mathrm{~g} / 1$

Levedura $=$ S. cerevisiae $(\mathrm{IZ}-888)$

Mel de laranjeira $=2,3 \mathrm{Kg}$

Agitação $=100 \mathrm{rpm}$

Ajuste de $\mathrm{pH}$ do mosto $=1,5 \mathrm{~g} / 1$ de ácido cítrico $+0,75 \mathrm{~g} / 1$ de fosfato de potássio

Correção de pH durante a fermentação $=\mathrm{KOH} 5 \mathrm{~N}$

Correção mineral: $1,587 \mathrm{~g} / 1$ de sulfato de amônio

$0,185 \mathrm{~g} / 1$ de cloreto de magnésio 
Tabela 18. Resultados da $2 \mathrm{a}$ fermentação do 60 experimento em batelada, com controle de pH com KOH $5 \mathrm{~N}$, por S. cerevisiae (IZ-888).

\begin{tabular}{|c|c|c|c|c|c|c|c|c|c|c|}
\hline $\begin{array}{l}\text { AMOSTRA } \\
\text { (no) }\end{array}$ & $\begin{array}{c}\text { TEMPO } \\
\text { (h) }\end{array}$ & $\begin{array}{l}1 \text { TEMPERAT. } \\
\left({ }^{\circ} \mathrm{C}\right)\end{array}$ & $\mathrm{pH}^{2}$ & $\begin{array}{c}\mathrm{KOH} \\
5 \mathrm{~N} \\
(\mathrm{ml})\end{array}$ & $\mathrm{pH}^{3}$ & $\begin{array}{c}\text { LEVEDURA } \\
\text { m.s. } \\
(g / l)\end{array}$ & $\begin{array}{l}\text { ÁLCOOL } \\
(\mathrm{ml} / 100 \mathrm{ml})\end{array}$ & $\begin{array}{l}\text { A.R.T } \\
(g / l)\end{array}$ & $\begin{array}{l}\text { ACIDEZ } \\
\text { TOTAL } \\
(g / 100 \mathrm{ml})\end{array}$ & $\begin{array}{l}\text { ACIDEZ } \\
\text { VOLÁTIL } \\
(g / 100 \mathrm{ml})\end{array}$ \\
\hline 1 & 0 & 25,0 & 4,04 & - & - & 0,25 & - & 172,94 & 0,20 & * \\
\hline 2 & 6,0 & 27,0 & 3,75 & 5 & 3,96 & 0,55 & 0,16 & 175,83 & 0,22 & 0,003 \\
\hline 3 & 28,0 & 25,5 & 2,54 & 35 & 3,88 & 2,33 & 1,79 & 174,62 & 0,32 & - \\
\hline 4 & 52,5 & 25,0 & 3,13 & 20 & 3,88 & 4,93 & 5,27 & 85,04 & 0,32 & 0,004 \\
\hline 5 & 72,0 & 24,0 & 3,79 & - & - & 5,93 & 7,91 & 43,45 & 0,30 & 0,011 \\
\hline 6 & 95,5 & 23,0 & 3,79 & - & - & 6,50 & 9,96 & 11,59 & 0,36 & 0,007 \\
\hline 7 & 100,5 & - & - & - & - & - & 9,96 & $*$ & - & - \\
\hline $\begin{array}{l}\text { AMOSTRA } \\
\text { (n०) }\end{array}$ & & $\begin{array}{l}\text { TEMPO' } \\
\text { (h) }\end{array}$ & $\begin{array}{r}\text { LEVEI } \\
\mathrm{m} . \\
(\mathrm{g}\end{array}$ & JRA & $\begin{array}{l}\text { ÁLCO } \\
(g / 100 r\end{array}$ & & $\begin{array}{l}\text { A.R.T. } \\
\text { (g) }\end{array}$ & & $\begin{array}{l}\text { CIDEZ } \\
\text { TOTAL } \\
\text { (g) }\end{array}$ & $\begin{array}{c}\text { ACIDEZ } \\
\text { VOLÁTIL } \\
\text { (g) }\end{array}$ \\
\hline 1 & & 0 & 2,50 & & - & & $1.729,40$ & & 20,0 & - \\
\hline 2 & & 6,0 & 5,5 & & 0,12 & & $1.758,30$ & & 22,0 & 0,30 \\
\hline 3 & & 28,0 & 23,3 & & 1,41 & & $1.746,20$ & & 32,0 & - \\
\hline 4 & & 52,5 & 49,3 & & 4,16 & & 850,40 & & 32,0 & 0,40 \\
\hline 5 & & 72,0 & 59,3 & & 6,25 & & 434,50 & & 30,0 & 1,10 \\
\hline 6 & & 95,5 & 65,0 & & 7,87 & & 115,90 & & 36,0 & 0,70 \\
\hline 7 & & 100,5 & - & & 7,87 & & * & & - & - \\
\hline
\end{tabular}




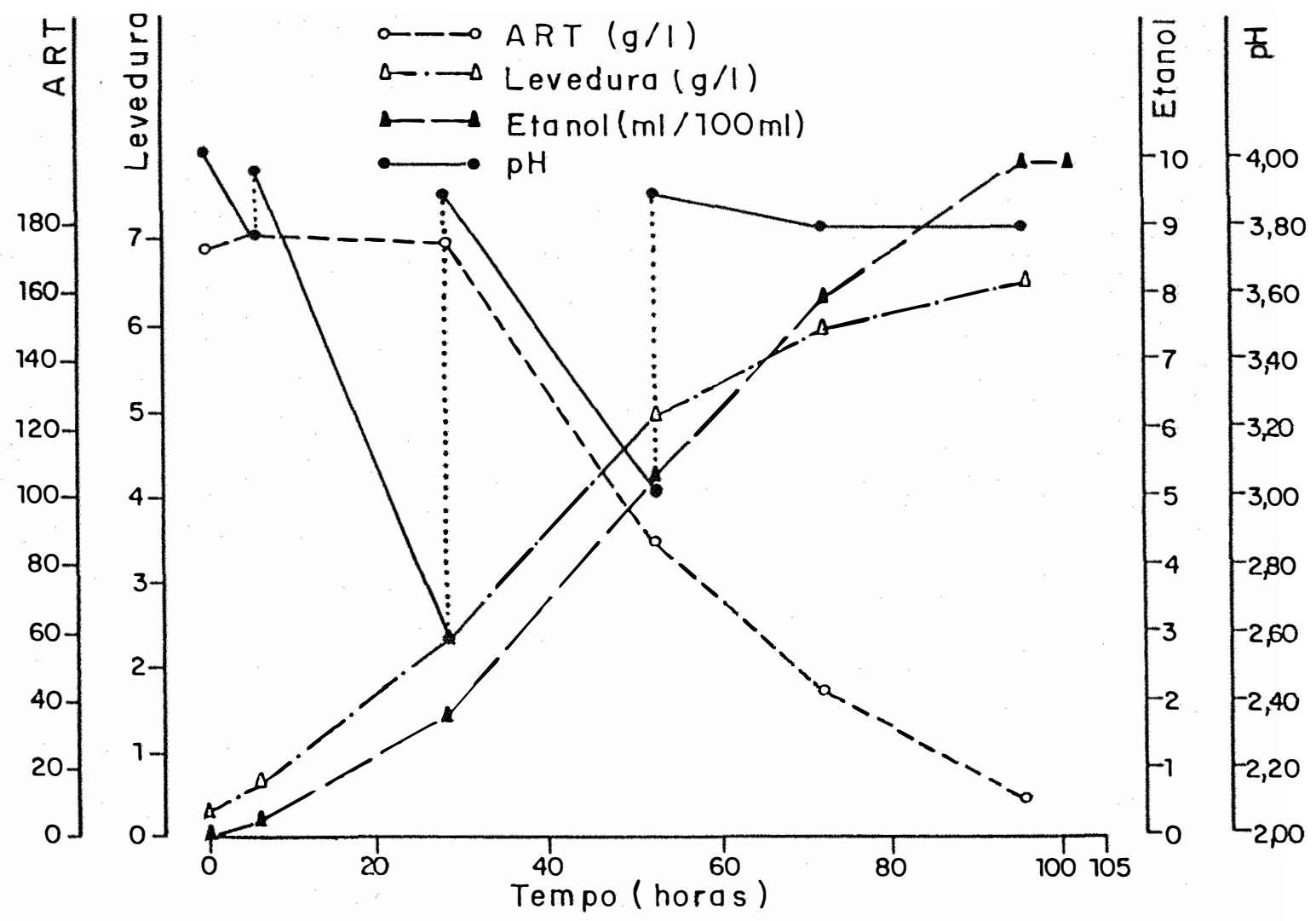

Figura 12-Acúcares redutores totais, massa celular, etanol e pH para a 2 o fermentaçāo do 6을 experimento em batelada.

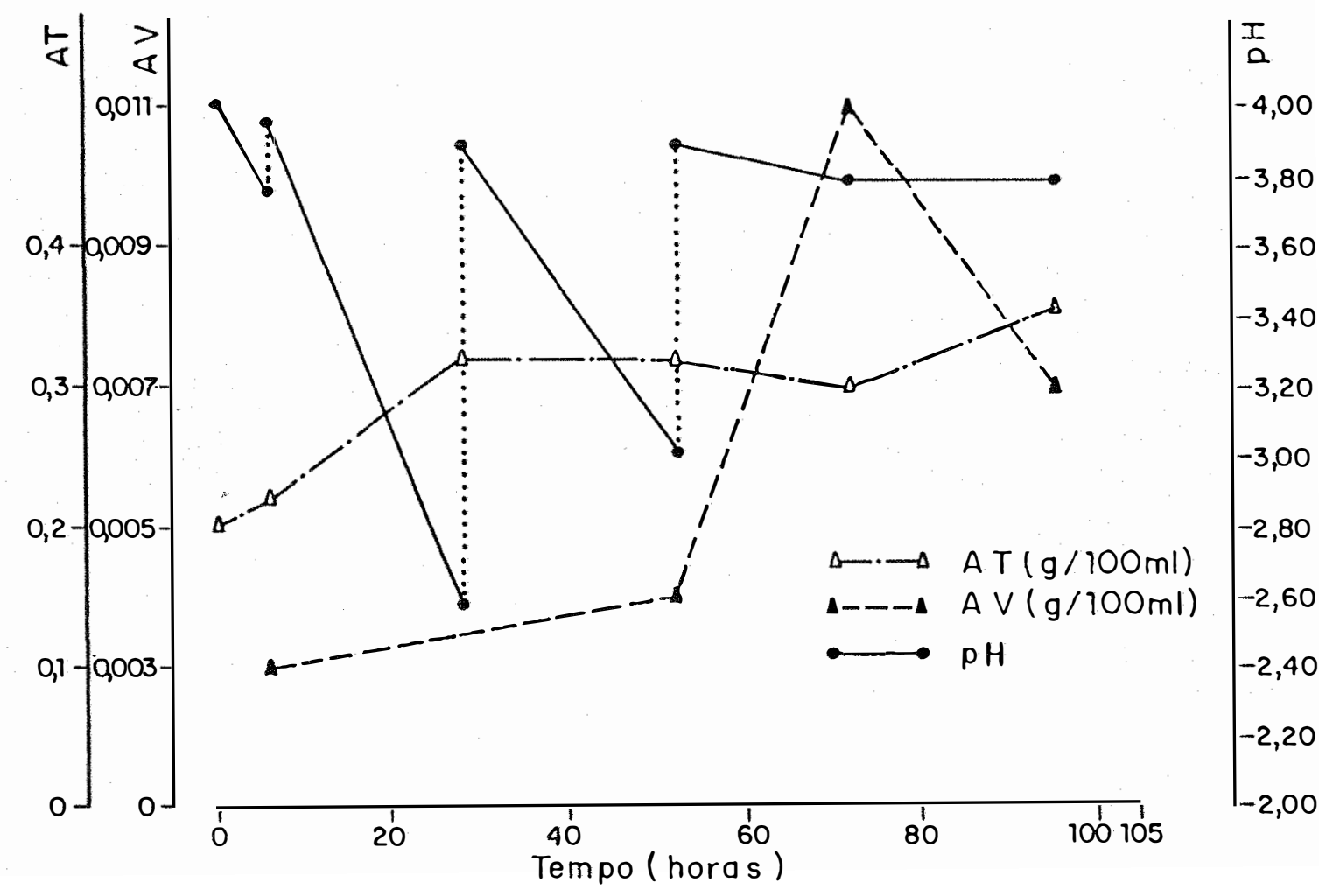

Figura 13-Ácidos totais ( $A T$ ), ácidos volóteis ( $A V$ ) e $\mathrm{pH}$ para a 2 a fer. mentaçāo do 6? experimento em batelada. 
Neste ensaio chamado sexto experimento, variou-se os teores de ácido cítrico e de fosfato de potássio, reduzindo o primeiro e acrescentando ou aumentando o segundo sal, formando assim, tampão citrato-fosfato. Foi utilizada a levedura isolada do fermento prensado no primeiro experimento e a $S$. cerevisiae (IZ-888) no segundo.

Nota-se que os resultados obtidos, mostrados as Tabelas 17 e 18 e Figuras 12 e 13, são muito semelhantes aos anteriores e que as viabilidades se mantiveram elevadas, de acordo com o obtido no experimento anterior. Assim, o uso de tamponante a base de citrato e fosfato, quando complementado com hidróxido de potássio durante a fermentação, funciona bem, mesmo variando-se as proporções.

A concentração inicial e final de fermento em ambos experimentos foi $0,25 \mathrm{~g} / 1$ e $6,50 \mathrm{~g} / 1$ de massa seca, atingindo $96 \%$ a produção de novas células.

A produrividade volumétrica no primeiro experimento foi de $0,57 \mathrm{ml} .1$ ${ }^{1} \cdot \mathrm{h}^{-1}$ e no segundo de $1,04 \mathrm{ml} \cdot \mathrm{J}^{-1} \cdot \mathrm{h}^{-1}$. Essa diferença ocorreu devido ao fato da pá do agitador soltar-se acidentalmente durante o primeiro experimento, provavelmente após às 72,00 horas de fermentação sendo corrigida por volta de 140,00 horas. Esse acaso tornou a fermentação mais demorada.

Os resultados desse experimento referentes a concentração celular das amostras 6 e 7 encontram-se com valores mais baixos que o esperado, devido o fermento ter-se depositado no fundo do fermentador e as amostras terem sido retiradas sem antes agitar o mosto. 
Semelhantemente ao ensaio anterior, os provadores identificaram ligeiro sabor e aroma de mel nos vinhos e leve aroma de fermento. Também aqui não houve distinção entre os vinhos produzidos com as diferentes leveduras.

\subsubsection{Sétimo experimento em batelada}

\section{Condições experimentais ( $1^{\mathrm{a}}$ fermentação)}

Concentração do mosto em ART $=175,33 \mathrm{~g} / 1$

Volume total do mosto $=10,0$ litros

Inóculo, massa seca $=0,26 \mathrm{~g} / 1$

Levedura $=$ linhagem isolada do fermento prensado

Mel de laranjeira $=2,3 \mathrm{Kg}$

Sem agitação

Ajuste de $\mathrm{pH}$ do mosto $=1,5 \mathrm{~g} / 1$ de ácido cítrico $+1,3 \mathrm{~g} / 1$ de fosfato de potássio Correção de pH durante a fermentação $=\mathrm{KOH} 5 \mathrm{~N}$

Correção mineral: $1,587 \mathrm{~g} / 1$ de sulfato de amônio

$$
\text { 0,185 g/l de cloreto de magnésio }
$$


Tabela 19. Resultados da 1a fermentação do 70 experimento em batelada, sem agitação, com controle de $\mathrm{pH}$ com $\mathrm{KOH} 5 \mathrm{~N}$, pela linhagem de levedura isolada do fermento prensado.

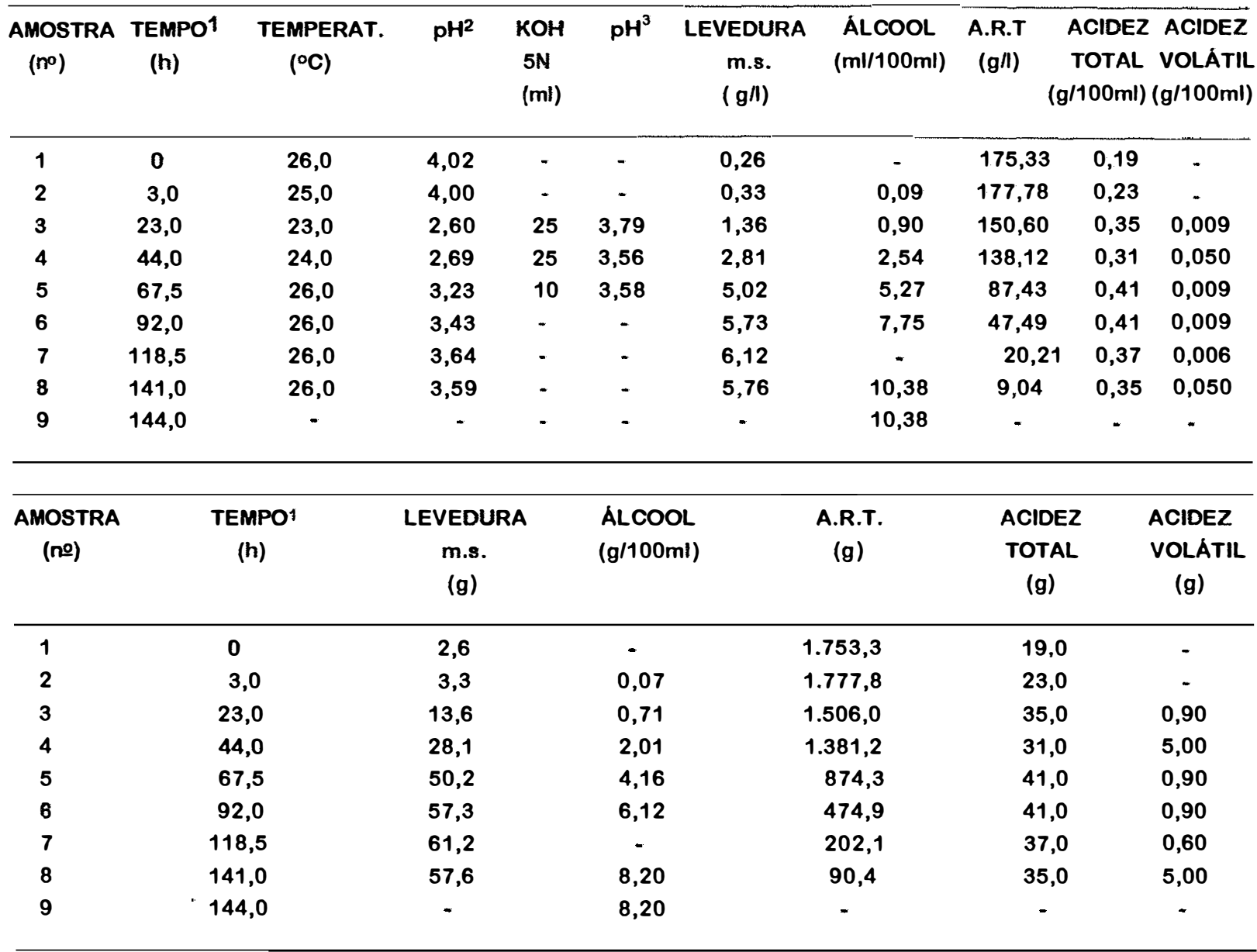

'- Tempo de fermentaçăo.

2- Antes da correção.

3 - Após adição de KOH 5 N. 


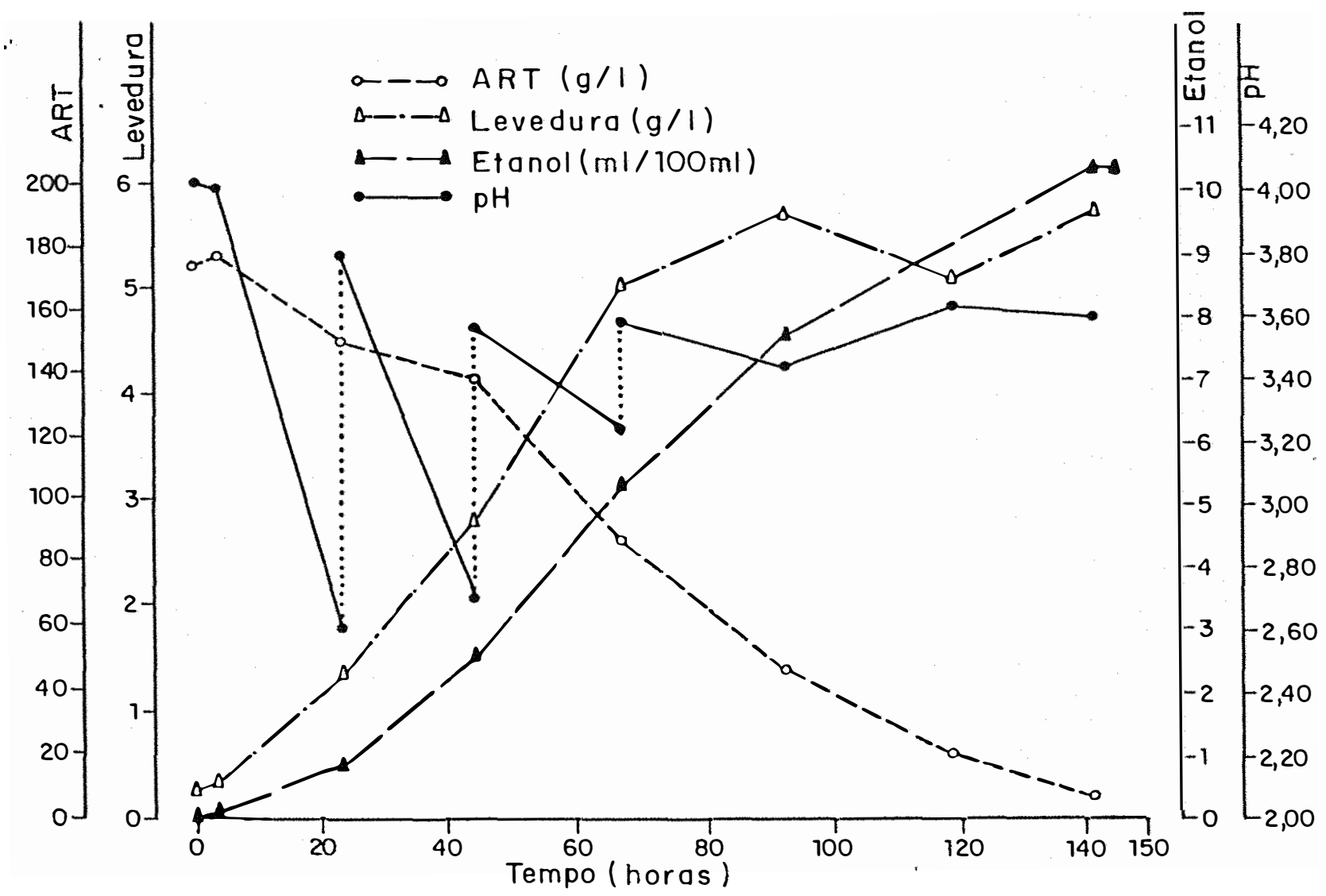

Figura 14-Acúcares redutores totais, massa celular, etanol e pH para a 1 a

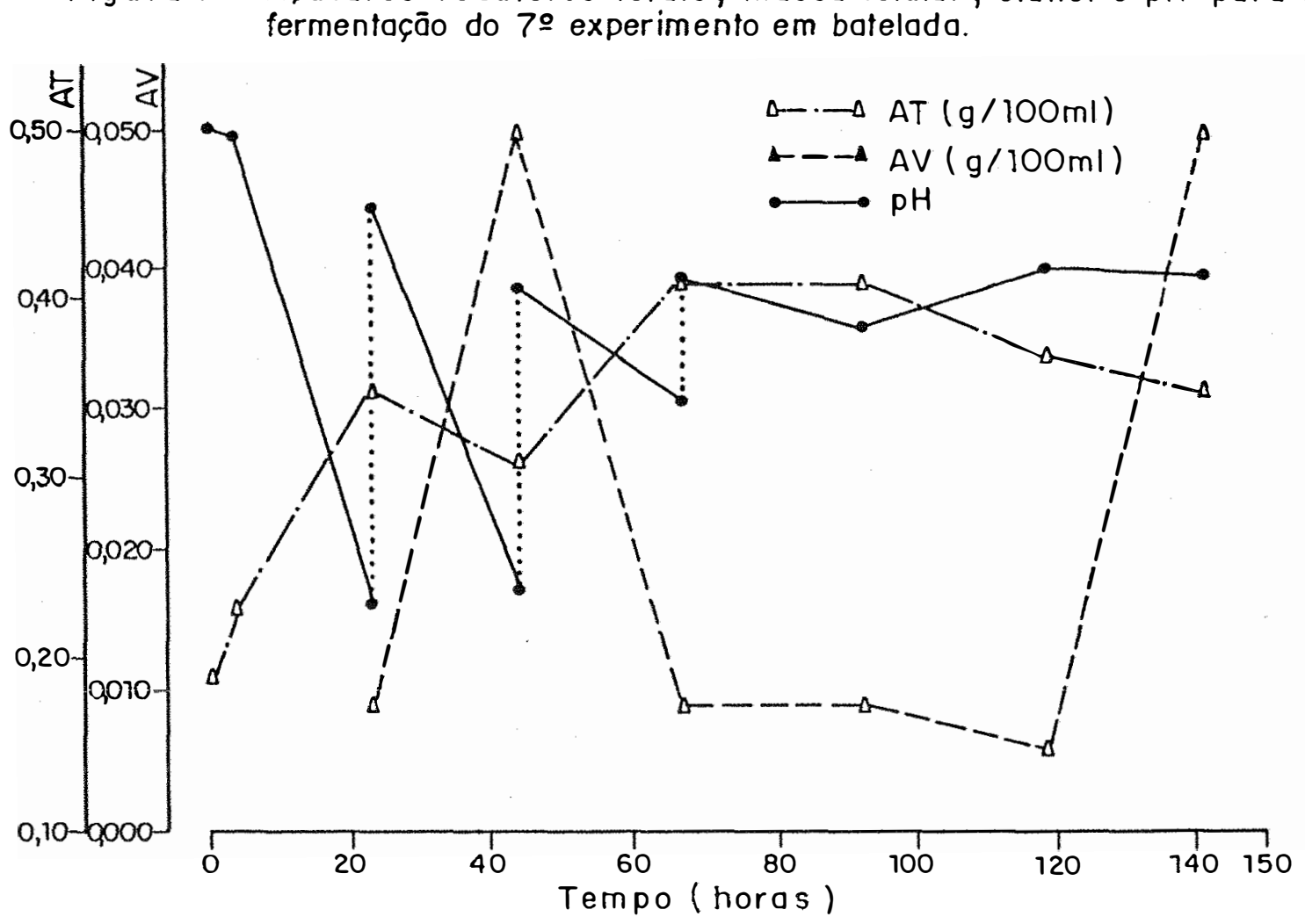

Figura 15-Ácidos totais ( $A T)$, ócidos voláteis ( $A V$ ) e $\mathrm{pH}$ para a 79 fermentaçāo do 7 을 experimento em batelada. 


\section{Condições experimentais ( $2^{\mathrm{a}}$ fermentação)}

Concentração do mosto em ART $=182,79 \mathrm{~g} / 1$

Volume total do mosto $=10,0$ litros

Inóculo, massa seca $=0,25 \mathrm{~g} / 1$

Levedura $=$ linhagem isolada do fermento prensado

Mel de laranjeira $=2,3 \mathrm{Kg}$

Sem agitação

Ajuste de $\mathrm{pH}$ do mosto $=1,5 \mathrm{~g} / \mathrm{l}$ de ácido cítrico $+1,27 \mathrm{~g} / \mathrm{l}$ de fosfato de potássio

Correção de $\mathrm{pH}$ durante a fermentação $=\mathrm{KOH} 5 \mathrm{~N}$

Correção mineral: $1,587 \mathrm{~g} / \mathrm{l}$ de sulfato de amônio

$0,185 \mathrm{~g} / 1$ de cloreto de magnésio 
Tabela 20. Resultados da 2a fermentação do 70 experimento em batelada, sem agitação, com controle de $\mathrm{pH}$ com $\mathrm{KOH} 5 \mathrm{~N}$, pela linhagem de levedura isolada do fermento prensado.

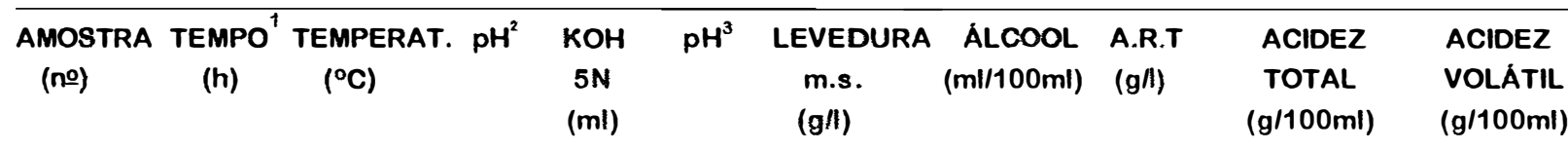

\begin{tabular}{rcccccccccc}
\hline 1 & 0 & 26,0 & 3,99 & - & - & 0,25 & - & 182,79 & 0,19 & - \\
2 & 3,0 & 25,0 & 3,98 & - & - & 0,32 & 0,09 & 175,85 & 0,23 & 0,009 \\
3 & 23,0 & 23,0 & 2,51 & 25 & 3,74 & 1,45 & 0,90 & 166,27 & 0,34 & 0,046 \\
4 & 44,0 & 24,0 & 2,66 & 25 & 3,50 & 2,81 & 2,68 & 140,04 & 0,31 & 0,011 \\
5 & 67,5 & 26,0 & 3,24 & 10 & 3,59 & 5,06 & 5,65 & 85,49 & 0,42 & 0,007 \\
6 & 92,0 & 26,0 & 3,42 & - & - & 5,75 & 7,91 & 55,35 & 0,39 & 0,046 \\
7 & 118,5 & 26,0 & 3,64 & - & - & 6,08 & - & 16,55 & 0,34 & 0,006 \\
8 & 141,0 & 26,0 & 3,60 & - & - & 5,76 & 10,30 & 9,28 & 0,34 & - \\
9 & 144,0 & - & - & - & - & - & 10,22 & - & - &
\end{tabular}

\section{AMOSTRA}

(no)

(h)

\section{LEVEDURA}

m.s.

(g) (g/100ml)

2,5

3,2

14,5

28,1

50,6

57,5

60,8

57,6

-
0,07
0,71
2,12
4,46
6,25
-
8,13
8,06

118,5

141,0

144,0

\section{A.R.T.}

(g)
ACIDEZ TOTAL

(g)

$1.827,90$
$1.758,50$
$1.662,70$
$1.400,40$
854,90
553,50
165,50
92,80

ACIDEZ

VOLÁTIL

(g)

$\begin{array}{cc}19,0 & - \\ 23,0 & - \\ 34,0 & 0,90 \\ 31,0 & 4,60 \\ 42,0 & 1,10 \\ 39,0 & 0,70 \\ 34,0 & 4,60 \\ 34,0 & 0,60 \\ - & -\end{array}$

\footnotetext{
1 - Tempo de fermentação.

2 - Antes da correção.

3 - Após adição de KOH 5 N.
} 
Nesse ensaio, foram realizadas duas fermentações com a utilização do tampão cirrato/fosfato e $\mathrm{KOH} 5 \mathrm{~N}$, em condições semelhantes ao ensaio anterior, exceto sem agitação contínua já que o agitador só era ligado para homogenizar o meio antes da retirada das amostras.

A partir desse ensaio optou-se em trabalhar apenas com a levedura isolada do fermento prensado comercial, em função dos resultados obtidos com as diferentes leveduras se apresentarem de forma muito semelhante tanto durante o andamento das fermentações quanto pelo produto final.

Iniciaram-se as fermentações com concenıação celular de 0,25 e 0,26 $\mathrm{g} / \mathrm{l}$ de massa seca, as quais finalizaram com massa celular em torno de $6,0 \mathrm{~g} / \mathrm{l}$.

Os resultados obtidos nesse ensaio podem ser observados nas Tabelas 19 e 20 e Figuras 14 e 15.

As fermentações foram consideradas encerradas após 141,00 horas, apresentando o vinho cerca de $10 \%$ de álcool (v/v) e produtividade volumétrica em torno de $0,70 \mathrm{ml} \cdot \mathrm{l}^{-1} \cdot \mathrm{h}^{-1}$.

Quanto a acidez volátil, esta apresentou-se de 0,006 e 0,050 g/100ml. A acidez total ficou em torno de $0,35 \mathrm{~g} / 100 \mathrm{ml}$, valor um pouco abaixo da legislação nacional de $0,37 \mathrm{~g} / 100 \mathrm{ml}$.

Os provadores não sentiram diferença organoléptica no vinho obtido nesse ensaio quando comparado com os dois ensaios anteriores. 


\subsubsection{Oitavo experimento em batelada}

\section{Condições experimentais ( $1^{2}$ fermentação)}

Concentração de mosto em ART $=177,24 \mathrm{~g} / 1$

Volume total do mosto $=10,0$ litros

Inóculo, massa seca $=0,18 \mathrm{~g} / 1$

Levedura $=$ linhagem isolada do fermento prensado

Mel de laranjeira $=2,3 \mathrm{Kg}$

Sem agitação

Ajuste de $\mathrm{pH}$ do mosto $=1,5 \mathrm{~g} / \mathrm{l}$ de ácido cítrico $+1,25 \mathrm{~g} / \mathrm{l}$ de fosfato de potássio

Sem correção de pH durante a fermentação

Correção mineral: $1,587 \mathrm{~g} / 1$ de sulfato de amônio

0,185 g/l de cloreto de magnésio 
Tabela 21. Resultados da 1a fermentação do 80 experimento em batelada, sem agitação e sem o uso de tamponantes, pela linhagem de levedura isolada do fermento prensado.

\begin{tabular}{|c|c|c|c|c|c|c|c|c|}
\hline $\begin{array}{l}\text { AMOSTRA } \\
\text { (n) }\end{array}$ & $\begin{array}{l}\text { TEMPO1 } \\
\text { (h) }\end{array}$ & $\begin{array}{l}\text { TEMPERAT. } \\
\left({ }^{\circ} \mathrm{C}\right)\end{array}$ & $\mathrm{pH}$ & $\begin{array}{l}\text { LEVEDURA } \\
\text { m.s. } \\
(g / l)\end{array}$ & $\begin{array}{c}\text { ALCOOL } \\
(\mathrm{ml} / 100 \mathrm{ml})\end{array}$ & $\begin{array}{c}\text { A.R.T } \\
(g / l)\end{array}$ & $\begin{array}{c}\text { ACIDEZ } \\
\text { TOTAL } \\
(\mathrm{g} / 100 \mathrm{ml})\end{array}$ & $\begin{array}{c}\text { ACIDEZ } \\
\text { VOLATIL } \\
(\mathrm{g} / 100 \mathrm{ml})\end{array}$ \\
\hline 1 & 0 & 24,1 & 3,86 & 0,18 & - & 177,24 & 0,20 & 0,005 \\
\hline 2 & 72,5 & - & 2,50 & . & - & - & - & - \\
\hline 3 & 97,5 & - & 2,43 & - & - & - & - & - \\
\hline 4 & 173,0 & - & 2,49 & - & 7,67 & - & - & - \\
\hline 5 & 190,5 & - & 2,52 & - & 8,32 & - & - & - \\
\hline 6 & 215,5 & - & - & - & 8,48 & - & - & - \\
\hline 7 & 237,0 & - & - & - & 8,56 & - & - & - \\
\hline 8 & 238,0 & 25,0 & 2,53 & 1,95 & 8,48 & 36,62 & 0,50 & 0,040 \\
\hline $\begin{array}{l}\text { AMOSTRA } \\
\text { (no) }\end{array}$ & $\begin{array}{l}\text { TEMPO1 } \\
\text { (h) }\end{array}$ & \multicolumn{2}{|c|}{$\begin{array}{l}\text { LEVEDURA } \\
\text { m.s. } \\
(\mathrm{g})\end{array}$} & $\begin{array}{c}\text { ALCOOL } \\
(\mathrm{g} / 100 \mathrm{ml})\end{array}$ & $\begin{array}{l}\text { A.R.T. } \\
\text { (g) }\end{array}$ & & $\begin{array}{l}\text { ACIDEZ } \\
\text { TOTAL } \\
\text { (g) }\end{array}$ & $\begin{array}{c}\text { ACIDEZ } \\
\text { VOLATIL } \\
\text { (g) }\end{array}$ \\
\hline 1 & 0 & \multicolumn{2}{|l|}{1,80} & - & $1.772,40$ & & 20,0 & 0,50 \\
\hline 2 & 72,5 & \multicolumn{2}{|l|}{-} & - & - & & - & - \\
\hline 3 & 97,5 & \multicolumn{2}{|l|}{ - } & - & - & & - & - \\
\hline 4 & 173,0 & \multicolumn{2}{|l|}{ - } & 6,05 & - & & - & - \\
\hline 5 & 190,5 & \multicolumn{2}{|l|}{ - } & 6,56 & - & & - & - \\
\hline 6 & 215,5 & \multicolumn{2}{|l|}{ - } & 6,69 & - & & - & - \\
\hline 7 & 237,0 & \multicolumn{2}{|l|}{ - } & 6,76 & - & & - & - \\
\hline 8 & 238,0 & \multicolumn{2}{|l|}{19,50} & 6,69 & 336,20 & & 50,0 & 4,00 \\
\hline
\end{tabular}

1 - Tempo de fermentação. 


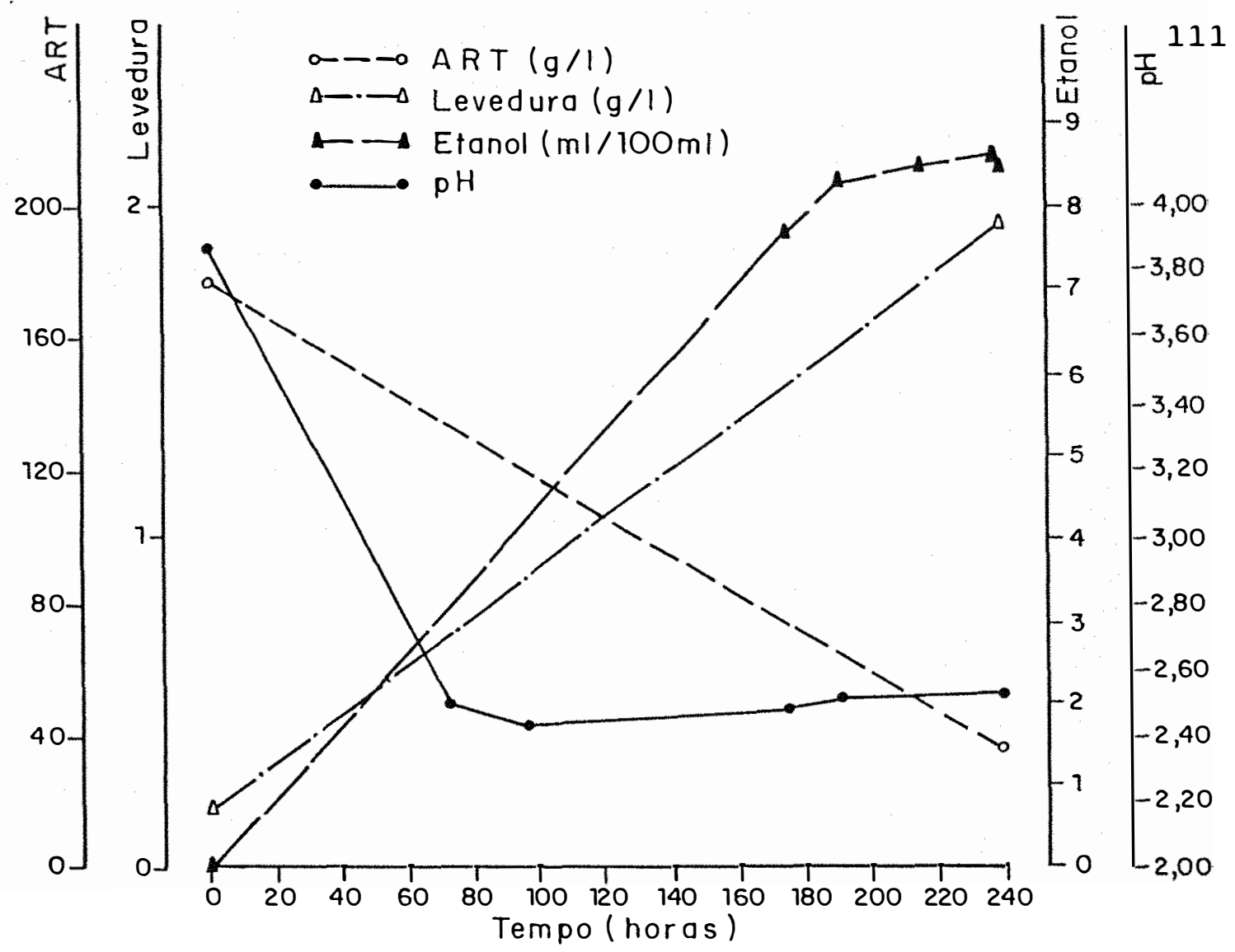

Figura 16-Acúcares redutores totais, massa celular, etanol e pH para a 1ㅇ fermentaçāo do 8 ㅇ experimento em batelada.

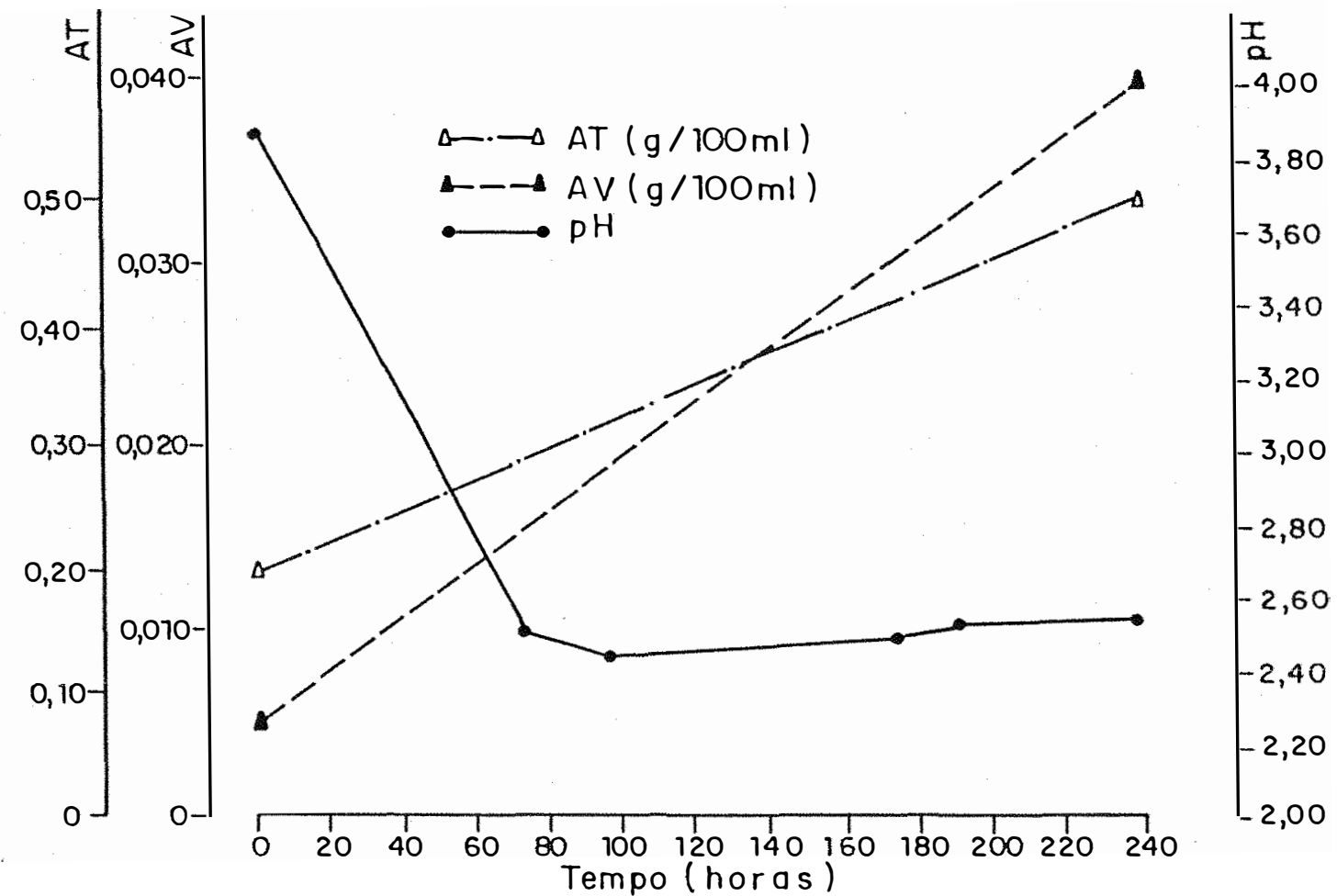

Figura 17-Ácidos totais (AT), ácidos voláteis (AV) e pH para o 1a fermen taçāo do 8 ? experimento em batelada. 


\section{Correção mineral ( $2^{2}$ fermentação)}

Concentração do mosto em ART $=186,43 \mathrm{~g} / 1$

Volume total do mosto $=10,0$ litros

Inóculo, massa seca $=0,20 \mathrm{~g} / 1$

Levedura $=$ linhagem isolada do fermento prensado

Mel de laranjeira $=2,3 \mathrm{Kg}$

Sem agitação

Ajuste de $\mathrm{pH}$ do mosto $=1,5 \mathrm{~g} / 1$ de ácido cítrico $+1,28 \mathrm{~g} / 1$ de fosfato de potássio

Sem correção de $\mathrm{pH}$ durante a fermentação

Correção mineral: $1,587 \mathrm{~g} / 1$ de sulfato de amônio

$0,185 \mathrm{~g} / 1$ de cloreto de magnésio 
Tabela 22. Resultados da 2a fermentação do 8 o experimento em batelada, sem agitação e sem o uso de tamponantes, pela linhagem de levedura isolada do fermento prensado.

\begin{tabular}{|c|c|c|c|c|c|c|c|c|}
\hline $\begin{array}{l}\text { AMOSTRA } \\
\text { (no) }\end{array}$ & $\begin{array}{c}\text { TEMPO } 1 \\
\text { (h) }\end{array}$ & $\begin{array}{l}\text { TEMPERAT. } \\
\left({ }^{\circ} \mathrm{C}\right)\end{array}$ & $\mathrm{pH}$ & $\begin{array}{c}\text { LEVEDURA } \\
\text { m.s. } \\
(g / l)\end{array}$ & $\begin{array}{l}\text { ÁLCOOL } \\
(\mathrm{ml} / 100 \mathrm{ml})\end{array}$ & $\begin{array}{l}\text { A.R.T } \\
(g / l)\end{array}$ & $\begin{array}{l}\text { ACIDEZ } \\
\text { TOTAL } \\
\text { (g/100ml) }\end{array}$ & $\begin{array}{l}\text { ACIDEZ } \\
\text { VOLATIL } \\
(\mathrm{g} / 100 \mathrm{ml})\end{array}$ \\
\hline 1 & 0 & 24,5 & 3,85 & 0,20 & - & 186,43 & 0,20 & 0,002 \\
\hline 2 & 196,0 & - & - & - & 7,83 & - & - & - \\
\hline 3 & 216,0 & - & - & - & 7,83 & - & - & - \\
\hline 4 & 220,0 & 24,0 & 2,30 & 3,08 & 7,83 & 44,76 & 0,50 & 0,036 \\
\hline $\begin{array}{l}\text { AMOSTRA } \\
\text { (no) }\end{array}$ & $\begin{array}{c}\text { TEMPO' } \\
\text { (h) }\end{array}$ & $\begin{array}{c}\text { LEVEDURA } \\
\text { m.s. } \\
\text { (g) }\end{array}$ & & $\begin{array}{c}\text { ALCOOL } \\
(g / 100 \mathrm{ml})\end{array}$ & $\begin{array}{l}\text { A.R.T. } \\
\text { (g) }\end{array}$ & \multicolumn{2}{|c|}{$\begin{array}{l}\text { ACIDEZ } \\
\text { TOTAL } \\
\text { (g) }\end{array}$} & $\begin{array}{c}\text { ACIDEZ } \\
\text { VOLÁTIL } \\
\text { (g) }\end{array}$ \\
\hline 1 & 0 & 2,00 & & - & $1.864,30$ & \multicolumn{2}{|c|}{20,0} & 0,20 \\
\hline 2 & 196,0 & - & & 6,18 & - & \multicolumn{2}{|r|}{-} & - \\
\hline 3 & 216,0 & - & & 6,18 & - & \multicolumn{2}{|r|}{-} & - \\
\hline 4 & 220,0 & 30,80 & & 6,18 & 447,60 & \multicolumn{2}{|c|}{50,0} & 3,60 \\
\hline
\end{tabular}

1 - Tempo de fermentação. 
Nesse ensaio as fermentações foram conduzidas sem agitação e sem o uso de tamponantes. O mosto, com aproximadamente $18 \%$ de ART, recebeu uma suplementação mineral como nos ensaios anteriores e a adição de $1,5 \mathrm{~g} / \mathrm{l}$ de ácido cítrico, o que trouxe o pH final ao redor de 3,85 .

A levedura foi multiplicada com o uso de tamponantes obtendo-se inóculo com 84 e $98 \%$ de viabilidade.

Os resultados obtidos nesse ensaio podem ser observados nas Tabelas 21 e 22 e Figuras 16 e 17.

Iniciaram-se as fermentações com 0,18 e $0,20 \mathrm{~g} / 1$ de massa seca e ao final a concentração celular foi de 1,95 e $3,08 \mathrm{~g} / 1$, o que representou 91 e $93 \%$ a produção de novas células, respectivamente.

Como já foi discutido em ensaios anteriores, na ausência de tamponantes o pH desce a níveis que afetam a fisiologia da levedura. Sendo assim, por volta de sexto dia de fermentação a viabilidade mostrou-se ao redor de $40 \%$, caindo para $7 \%$ no nono dia e chegando em torno de $3 \%$ quando foi cessada a fermentação diante da repetição do teor alcóolico.

A primeira fermentação cessou após 238,00 horas atingindo $8,48 \%$ de álcool $(\mathrm{v} / \mathrm{v})$, acidez total $0,50 \mathrm{~g} / 100 \mathrm{ml}$, acidez volátil $0,04 \mathrm{~g} / 100 \mathrm{ml}$ e $36,62 \mathrm{~g} / 1 \mathrm{de}$ açúcar residual, valores que se encontram de acordo com a legislação nacional.

Na segunda fermentação desse ensaio, encontraram-se valores bem próximos aos anteriores, sendo que a fermentação cessou após 196,00 horas alcançando 
$7,83 \%$ de álcool (v/v), acidez total $0,50 \mathrm{~g} / 100 \mathrm{ml}$, acidez volátil $0,036 \mathrm{~g} / 100 \mathrm{ml}$ e 44,76 g/l de açúcar residual.

Os vinhos resultantes foram bem aceitos e apreciados pelos provadores devido ao gosto adocicado, o que deve ter camuflado o sabor a fermento. Apesar da boa aceitação a produtividade foi muito baixa, estando em torno de $0,40 \mathrm{ml} \cdot \mathrm{l}^{-1} \cdot \mathrm{h}-1$.

Observa-se pelos resultados do sétimo e oitavo experimento que se não houver essencialidade na agitação constante da dorna ao longo de toda a fermentação, por outro lado, há necessidade do acompanhamento e correção de pH para se atingir um rendimento satisfatório do vinho.

\subsection{Fermentações conduzidas em batelada alimentada}

Ao se procederem os experimentos para escolha da concentração celular inicial, ao menos em relação aos fermentos não selecionados para produção de hidromel, chegou-se a conclusão que devido ao aroma e sabor a fermento ("yeasty" ou "sulphury") segundo THORNE et al. (1971), causados principalmente por $\mathrm{H}_{2} \mathrm{~S}$ e mercaptanas, produtos normais do metabolismo de leveduras, o teor de matéria seca inicial deveria ser tão baixo quanto $0,3 \mathrm{~g} / 1$.

Ao se concluir que deveria ser iniciada a fermentação com $0,3 \mathrm{~g}$ de matéria seca por litro, uma quantidade pequena de células para um grande volume de mosto, deduziu-se que a condução do processo em batelada ou em batelada alimentada poderia não diferir e não trazer ganhos palpáveis em produtividade. 
Os possíveis ganhos em produtividade baseavam-se no teor de células que deveria ser maior em relação ao volume inicial de mosto, decrescendo ao longo do enchimento mas também compensando parte em função do crescimento celular. Esperava-se ainda um parcial controle de pH pela adição de novo lote de mosto, de modo que pudesse talvez apresentar uma fórmula mais econômica de produzir e controlar o processo. Ainda assim, foram conduzidos vários experimentos descritos a seguir para avaliar as hipóteses aventadas.

Os experimentos aqui relatados são constituídos de uma série de ensaios sucessivos ou concomitantes, que foram conduzidos em batelada alimentada, com agitação e correção de pH com diferentes reagentes. 
4.4.1. Batelada alimentada com agitação e correção de pH com solução de hidróxido de potássio

\section{Condições experimentais ( $1^{2}$ fermentação)}

Concentração do mosto em ART $=173,24 \mathrm{~g} / 1$

Volume total do mosto adicionado $=10,0$ litros

Alimentação $=2,5$ litros a cada 24 horas

Inóculo, massa seca $=0,76 \mathrm{~g} / 1$

Levedura $=$ linhagem isolada do fermento prensado

Mel de laranjeira $=575 \mathrm{~g} /$ alimentação (total $=2,3 \mathrm{Kg}$ )

Ajuste de $\mathrm{pH}$ do mosto $=1,5 \mathrm{~g} / 1$ de ácido círrico $+1,2 \mathrm{~g} / 1$ de fosfato de potássio

Correção de $\mathrm{pH}$ durante a fermentação $=\mathrm{KOH} 5 \mathrm{~N}$

Agitação $=100 \mathrm{rpm}$

Correção mineral: $1,587 \mathrm{~g} / 1$ de sulfato de amônio

$0,185 \mathrm{~g} / 1$ de cloreto de magnésio 
Tabela 23. Resultados da 1a fermentação do experimento em batelada alimentada, com controle de $\mathrm{pH}$ com $\mathrm{KOH} 5 \mathrm{~N}$, pela linhagem de levedura isolada do fermento prensado.

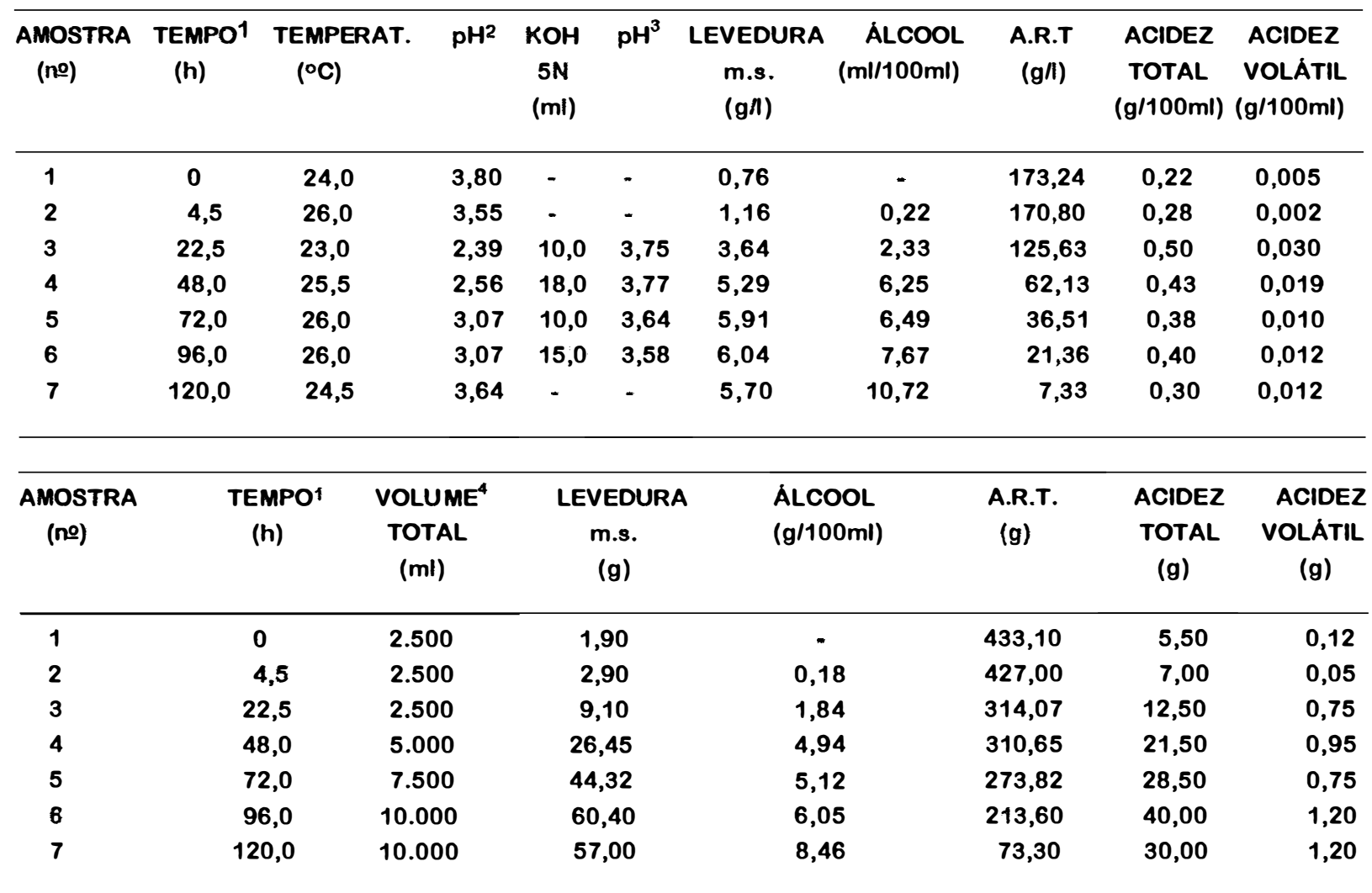

1 - Tempo de fermentação.

2- Antes da correção.

3 - Após adição de KOH $5 \mathrm{~N}$

4 - A adição do mosto em batelada alimentada foi realizada em frações de $2.500 \mathrm{ml}$, a cada 24 horas, sendo a aliquota retirada imediatamente antes de cada adição. 
Condiçōes experimentais ( $2^{a}$ fermentação)

Concentração do mosto em ART $=186,94 \mathrm{~g} / 1$

Volume total do mosto adicionado $=10,0$ litros

Inóculo, massa seca $=0,89 \mathrm{~g} / 1$

Levedura $=$ linhagem isolada do fermento prensado

Mel de laranjeira $=575 \mathrm{~g} /$ alimentação $($ total $=2,3 \mathrm{Kg}$ )

Ajuste de $\mathrm{pH}$ do mosto $=1,5 \mathrm{~g} / 1$ de ácido cítrico $+1,2 \mathrm{~g} / 1$ de fosfato de potássio

Correção de pH durante a fermentação $=\mathrm{KOH} 5 \mathrm{~N}$

Agitação $=100 \mathrm{rpm}$

Correção mineral: 1,587 g/1 de sulfato de amônio

$0,185 \mathrm{~g} / 1$ de cloreto de magnésio 
Tabela 24. Resultados da 2a fermentação do experimento em batelada alimentada, com controle de $\mathrm{pH}$ com KOH $5 \mathrm{~N}$, pela linhagem de levedura isolada do fermento prensado.

\begin{tabular}{|c|c|c|c|c|c|c|c|c|c|c|}
\hline $\begin{array}{l}\text { AMOSTRA } \\
\text { (n) }\end{array}$ & $\begin{array}{c}\text { TEMPO } \\
\text { (h) }\end{array}$ & $\begin{array}{l}\text { TEMPERAT. } \\
\left({ }^{\circ} \mathrm{C}\right)\end{array}$ & $\mathrm{pH}^{2}$ & $\begin{array}{l}\mathrm{KOH} \\
5 \mathrm{~N} \\
(\mathrm{ml})\end{array}$ & $\mathrm{pH}^{3}$ & $\begin{array}{c}\text { LEVEDURA } \\
\text { m.s. } \\
(g / l)\end{array}$ & $\begin{array}{l}\text { ALCOOL } \\
(\mathrm{ml} / 100 \mathrm{ml})\end{array}$ & $\begin{array}{r}\text { A.R.T } \\
(g / l)\end{array}$ & $\begin{array}{l}\text { ACIDEZ } \\
\text { TOTAL } \\
\text { (g/100ml) }\end{array}$ & $\begin{array}{l}\text { ACIDEZ } \\
\text { VOLÁTIL } \\
\text { (g/100ml) }\end{array}$ \\
\hline 1 & 0 & 24,5 & 3,78 & - & - & 0,89 & - & 186,94 & 0,29 & 0,005 \\
\hline 2 & 4,5 & 25,0 & 3,50 & - & - & 1,40 & 0,36 & 183,42 & 0,29 & 0,007 \\
\hline 3 & 24,0 & 24,0 & 2,23 & 15,0 & 4,07 & 4,14 & 2,68 & 129,74 & 0,49 & 0,042 \\
\hline 4 & 48,0 & 24,0 & 2,80 & 15,0 & 3,71 & 6,03 & 5,72 & 81,43 & 0,42 & 0,013 \\
\hline 5 & 72,0 & 23,0 & 2,97 & 22,0 & 3,71 & 7,25 & 7,27 & 52,31 & 0,49 & 0,007 \\
\hline 6 & 96,0 & 24,0 & 3,30 & 10,0 & 3,63 & 6,51 & 8,32 & 35,73 & 0,31 & 0,005 \\
\hline 7 & 120,0 & 24,0 & 3,62 & - & - & 6,70 & 9,96 & 8,99 & 0,31 & 0,005 \\
\hline 8 & 123,5 & - & - & - & - & - & 9,96 & - & - & * \\
\hline
\end{tabular}

\begin{tabular}{cccccccc}
\hline $\begin{array}{c}\text { AMOSTRA } \\
(\mathrm{n} \text { ) }\end{array}$ & $\begin{array}{c}\text { TEMPO1 } \\
(\mathrm{h})\end{array}$ & $\begin{array}{c}\text { VOLUME } \\
\text { TOTAL } \\
(\mathrm{ml})\end{array}$ & $\begin{array}{c}\text { LEVEDURA } \\
\text { m.s. }\end{array}$ & $\begin{array}{c}\text { ALCOOL } \\
(\mathrm{g})\end{array}$ & $\begin{array}{c}\text { A.R.T. } \\
(\mathrm{g} / 100 \mathrm{ml})\end{array}$ & $\begin{array}{c}\text { ACIDEZ } \\
\text { TOTAL } \\
(\mathrm{g})\end{array}$ & $\begin{array}{c}\text { ACIDEZ } \\
\text { VOLATIL } \\
(\mathrm{g})\end{array}$ \\
\hline 1 & & 2.500 & 2,22 & - & 467,35 & 7,25 & 0,12 \\
2 & 0 & 2.500 & 3,50 & 0,28 & 458,55 & 7,25 & 0,17 \\
3 & 4,5 & 2.500 & 10,35 & 2,12 & 324,35 & 11,66 & 1,00 \\
4 & 24,0 & 5.000 & 30,15 & 4,51 & 407,15 & 20,24 & 0,63 \\
5 & 48,0 & 7.500 & 54,37 & 5,74 & 392,32 & 11,66 & 0,17 \\
6 & 72,0 & 10.000 & 65,10 & 6,56 & 357,30 & 30,26 & 0,12 \\
7 & 96,0 & 10.000 & 67,00 & 7,87 & 89,90 & 30,26 & 0,12
\end{tabular}

1 - Tempo de fermentação.

2 - Antes da correção.

3 - Após adição de KOH $5 \mathrm{~N}$

4 - A adição do mosto em batelada alimentada foi realizada em frações de $2.500 \mathrm{ml}$, a cada 24 horas, sendo a aliquota retidada omediatamente antes de cada adição. 


\section{Condições experimentais ( $3^{a}$ fermentação)}

Concentração do mosto em ART $=180,92 \mathrm{~g} / 1$

Volume total do mosto adicionado $=10,0$ litros

Inóculo, massa seca $=0,86 \mathrm{~g} / 1$

Levedura $=$ linhagem isolada do fermento prensado

Mel de laranjeira $=575 \mathrm{~g} /$ alimentação $($ total $=2,3 \mathrm{Kg}$ )

Agitação $=100 \mathrm{rpm}$

Ajuste de $\mathrm{pH}$ do mosto $=1,5 \mathrm{~g} / 1$ de ácido cítrico $+1,24 \mathrm{~g} / 1$ de fosfato de potássio

Correção de pH durante a fermentação $=\mathrm{KOH} 5 \mathrm{~N}$

Correção mineral: 1,587 g/l de sulfato de amônio

$0,185 \mathrm{~g} / \mathrm{l}$ de cloreto de magnésio 
Tabela 25. Resultados da 3a fermentação do experimento em batelada alimentada, com controle de pH com KOH $5 \mathrm{~N}$, pela linhagem de levedura isolada do fermento prensado.

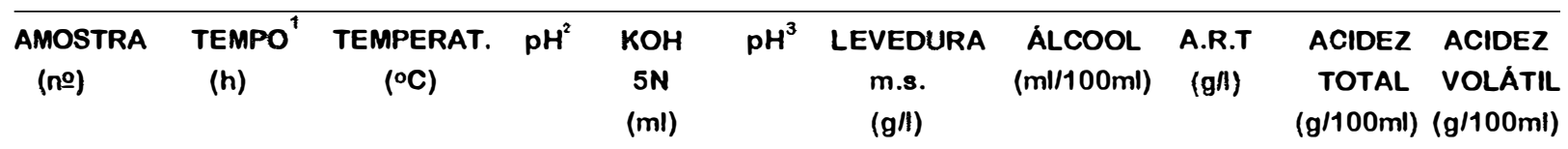

\begin{tabular}{rcccccccccc}
\hline 1 & 0 & 24,5 & 3,79 & - & - & 0,86 & - & 180,92 & 0,26 & 0,002 \\
2 & 4,5 & 25,0 & 3,59 & - & - & 1,32 & 0,36 & 181,39 & 0,29 & 0,005 \\
3 & 24,0 & 24,0 & 2,21 & 15,0 & 4,04 & 3,89 & 2,89 & 124,74 & 0,55 & 0,040 \\
4 & 48,0 & 24,0 & 2,79 & 15,0 & 3,71 & 6,11 & 5,80 & 77,84 & 0,49 & 0,007 \\
5 & 72,0 & 23,0 & 2,96 & 22,0 & 3,71 & 6,75 & 7,43 & 53,74 & 0,42 & 0,009 \\
6 & 96,0 & 24,0 & 3,31 & 10,0 & 3,65 & 6,49 & 8,48 & 35,09 & 0,34 & 0,005 \\
7 & 120,0 & 24,0 & 3,63 & - & - & 6,67 & 9,96 & 9,33 & 0,33 & 0,005 \\
8 & 123,5 & - & - & - & - & - & 9,89 & - & - & - \\
\hline
\end{tabular}

\section{AMOSTRA}

(no)

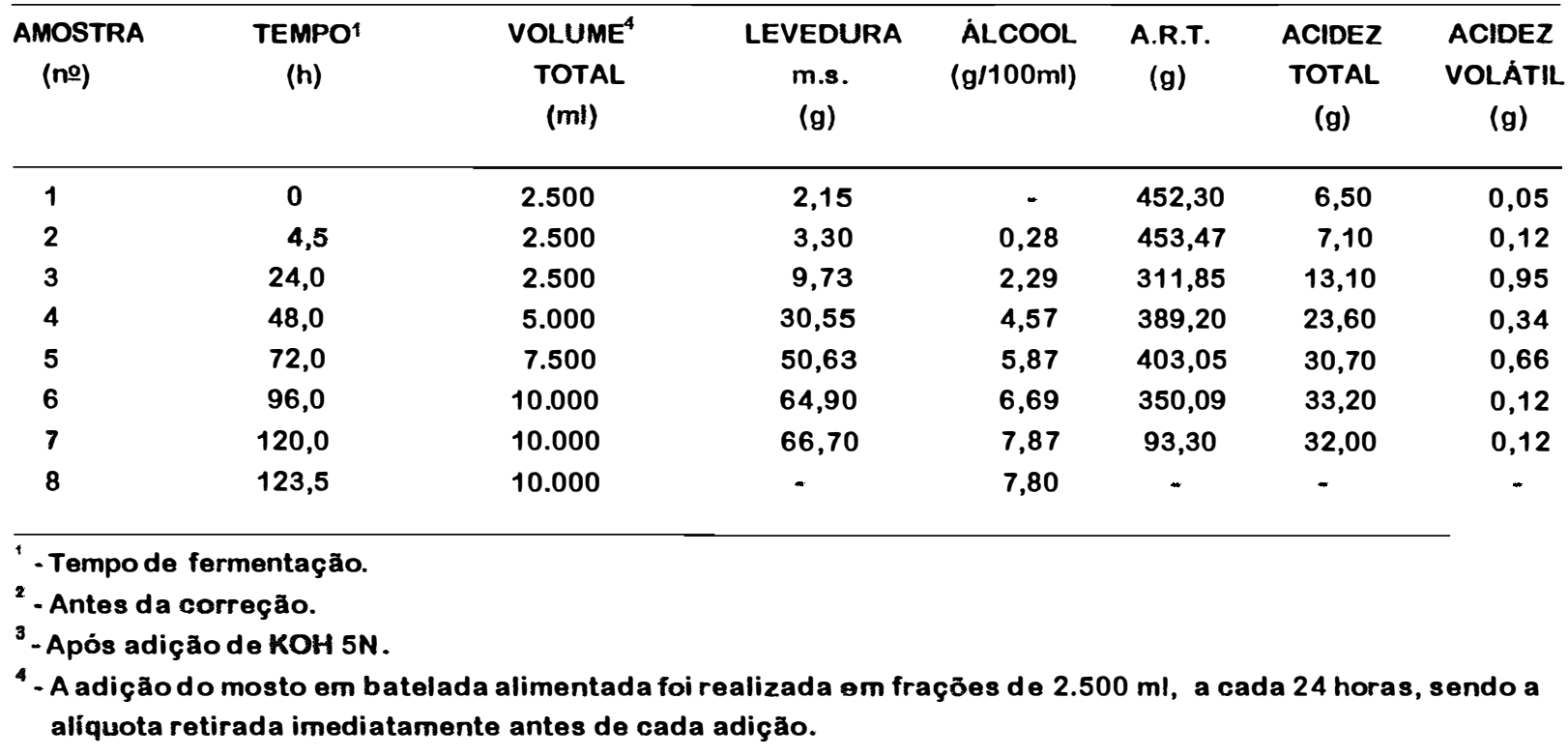




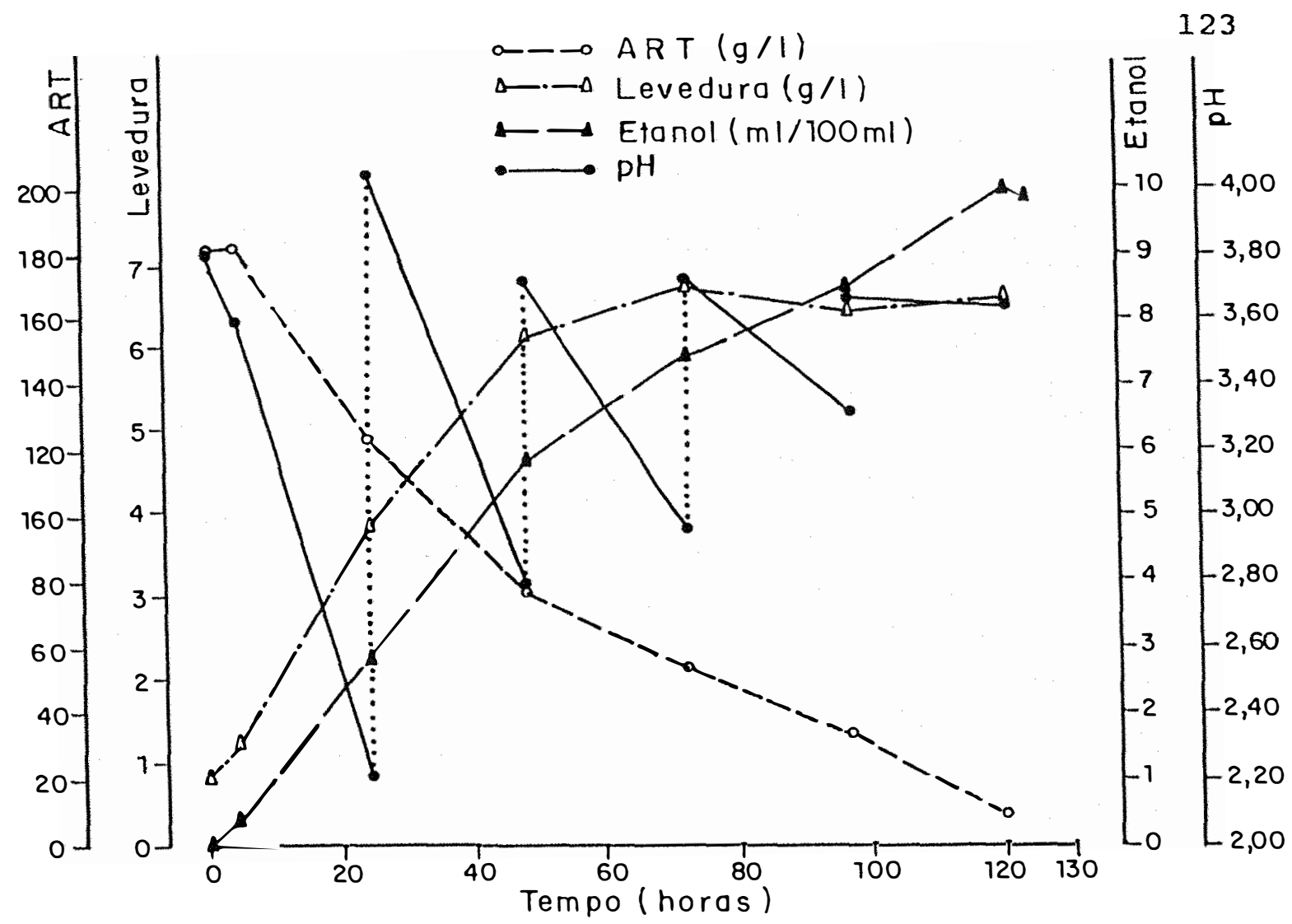

Figura 18-Acúcares redutores totais, massa celular, etanol e pH para a 39 fermentação do experimento em batelada alimentada.

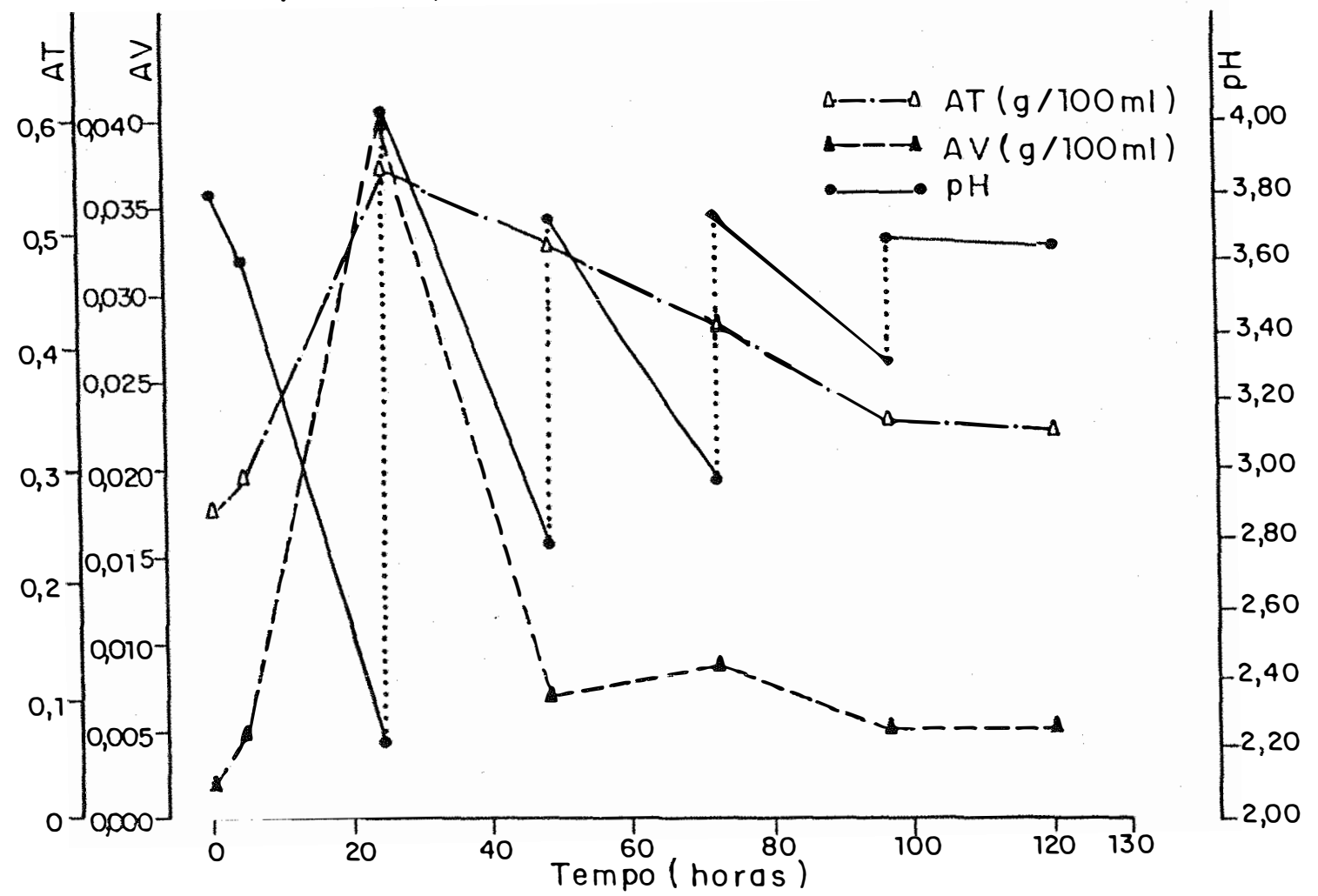

Figura 19 - Ácidos totais ( $A T$ ), dicidos voláteis ( AV) e pH para a 3a fermentaçäo do experimento em batelada alimentada. 
A obtenção do inóculo inicial foi feita conforme descrito nos experimentos em batelada, item 3.5 .

As condições experimentais de condução da fermentação e os resultados obtidos estão mostrados as Tabelas 23, 24 e 25 e Figuras 18 e 19.

Conforme se verifica as Tabelas 23,24 e 25 , apresentadas, a concentração inicial de inóculo é cerca de 4 vezes superior a adotada em batelada. Isto ocorre, porque o preparo de inóculo foi conduzido identicamente nos dois processos e na hora 0 , em batelada convencional ela serviu para inocular 10 litros de mosto, enquanto, na batelada alimentada, ela serviu para inocular apenas 2,5 litros. Pelo crescimento da massa celular e pelo consumo de açúcares pode-se observar que realmente ocorre um ganho de produtividade, no início do processo, durante o enchimento da dorna em batelada alimentada e que, esse ganho na forma como foram conduzidos os ensaios seriam da ordem de um dia ou 24 horas e , talvez, pudesse ter ganhos mais sensíveis se contássemos com equipamentos mais sofisticados de controle de $\mathrm{pH}$ e de enchimento em frações de tempos menores que as 24 horas adotadas. Entretanto, como na prática de produção não haverá sequer fermentadores como os utilizados, a adoção de tecnologia mais avançada serviria apenas como subsídio a estudos de fermentação, no momento. É muito provável ainda, que num processo mais sofisticado se possa usar menos e melhor os tamponantes e neutralizantes, obtendo, assim, um produto que somente na fermentação se obtenha dentro dos padrões de qualidade estabelecidos pelo SIPV, sem preocupação de correção do produto final com 
ácidos e adoçantes como indicados por MAUGENET (1964) e JARCZYK \& WZOREK (1977).

Nos processos em batelada e batelada alimentada, os parâmetros obtidos para concentração de massa celular final, etanol, de acidez foram idênticos de modo que a adoção de uma ou outra condução dependerá da maior flexibilidade de trabalho, melhor utilização de equipamentos, disponibilidade de matéria-prima e mão de obra, e otimização do processo como um todo.

4.4.2. Batelada alimentada com agitação e correção de pH com sal de fosfato de potássio $\left(\mathrm{K}_{2} \mathrm{HPO}_{4}\right)$.

\section{Condições experimentais ( $4^{a}$ fermentação)}

Concentração do mosto em ART $=216,10 \mathrm{~g} / 1$

Volume total do mosto adicionado $=10,0$ litros

Inóculo, massa seca $=1,0 \mathrm{~g} / 1$

Levedura $=$ linhagem isolada do fermento prensado

Mel de laranjeira $=708,5 \mathrm{~g} /$ alimentação $($ total $=2,83 \mathrm{Kg}$ )

Agitação $=100 \mathrm{rpm}$

Ajuste de $\mathrm{pH}$ do mosto $=1,5 \mathrm{~g} / 1$ de ácido cítrico $+1,2 \mathrm{~g} / 1$ de fosfato de potássio

Correção de pH durante a fermentação $=\mathrm{K}_{2} \mathrm{KPO}_{4}$

Correção mineral: $1,587 \mathrm{~g} / 1$ de sulfato de amônio

$0,185 \mathrm{~g} / 1$ de cloreto de magnésio 
Tabela 26. Resultados da 4 a fermentação do experimento em batelada alimentada, com controle de pH com $\mathrm{K}_{2} \mathrm{HPO}_{4}$, pela linhagem de levedura isolada do fermento prensado.

\begin{tabular}{|c|c|c|c|c|c|c|c|c|c|c|}
\hline $\begin{array}{l}\text { AMOSTRA } \\
\text { (no) }\end{array}$ & $\begin{array}{c}\text { TEMPO }{ }^{1} \\
\text { (h) }\end{array}$ & $\begin{array}{c}\text { TEMPERAT. } \\
\left({ }^{\circ} \mathrm{C}\right)\end{array}$ & $\mathrm{pH}^{2}$ & $\begin{array}{c}\mathrm{K}_{2} \mathrm{HPO}_{4} \\
(\mathrm{~g})\end{array}$ & $\mathrm{pH}^{3}$ & $\begin{array}{l}\text { LEVEDURA } \\
\text { m.s. } \\
(g / l)\end{array}$ & $\begin{array}{c}\text { ÁLCOOL } \\
(\mathrm{ml} / 100 \mathrm{ml})\end{array}$ & $\begin{array}{l}\text { A.R.T } \\
(g / l)\end{array}$ & $\begin{array}{l}\text { ACIDEZ } \\
\text { TOTAL } \\
\text { (g/100ml) }\end{array}$ & $\begin{array}{l}\text { ACIDEZ } \\
\text { VOLÁTIL } \\
(g / 100 \mathrm{ml})\end{array}$ \\
\hline 1 & 0 & 24,5 & 3,78 & - & - & 1,00 & - & 216,10 & 0,25 & 0,006 \\
\hline 2 & 5,0 & 25,0 & 3,41 & 1,5 & 3,57 & 1,76 & 0,36 & 213,95 & 0,31 & 0,007 \\
\hline 3 & 24,0 & 26,0 & 2,04 & 12,5 & 3,67 & 4,54 & 3,25 & 162,09 & 0,46 & 0,020 \\
\hline 4 & 48,0 & 24,0 & 2,74 & 12,5 & 3,50 & 7,00 & 5,65 & 119,73 & 0,52 & 0,007 \\
\hline 5 & 72,0 & 23,5 & 3,08 & 15,0 & 3,60 & 6,47 & 6,88 & 97,83 & 0,57 & 0,007 \\
\hline 6 & 96,0 & 23,0 & 3,24 & 8,0 & 3,54 & 6,00 & 7,51 & 87,10 & 0,51 & 0,018 \\
\hline 7 & 120,0 & 25,0 & - & - & - & - & 9,47 & - & - & - \\
\hline 8 & 125,0 & 25,0 & 3,56 & - & - & 6,78 & 9,88 & 48,27 & 0,57 & 0,005 \\
\hline
\end{tabular}

AMOSTRA

(no)
TEMPO1

(h)

VOLUME ${ }^{4}$

TOTAL

(ml)

LEVEDURA

m.s.

(g)
ÁLCOOL

(g/100ml)

A.R.T. ACIDEZ ACIDEZ

(g) TOTAL VOLÁTIL

(g)

(g)

\begin{tabular}{rrrrrrrr}
\hline 1 & 0 & 2.500 & 2,50 & - & 540,25 & 6,25 & 0,15 \\
2 & 5,0 & 2.500 & 4,40 & 0,28 & 534,87 & 7,75 & 0,17 \\
3 & 24,0 & 2.500 & 11,35 & 2,56 & 405,22 & 11,50 & 0,50 \\
4 & 48,0 & 5.000 & 35,00 & 4,46 & 598,65 & 26,00 & 0,35 \\
5 & 72,0 & 7.500 & 48,52 & 5,43 & 733,72 & 42,75 & 0,52 \\
6 & 96,0 & 10.000 & 60,00 & 5,93 & 871,00 & 51,00 & 1,80 \\
7 & 120,0 & 10.000 & - & 7,47 & - & - & - \\
8 & 125,0 & 10.000 & 67,80 & 7,80 & 482,70 & 57,00 & 0,50
\end{tabular}

\footnotetext{
' - Tempo de fermentação.
}

2 - Antes da correção.

3 - Após adição de $\mathrm{K}_{2} \mathrm{HPO}_{4}$.

4 - A adição do mosto em batelada alimentada foi realizada em frações de $2.500 \mathrm{ml}$, a cada 24 horas, sendo a aliquota retirada imediatamente antes de cada adição. 


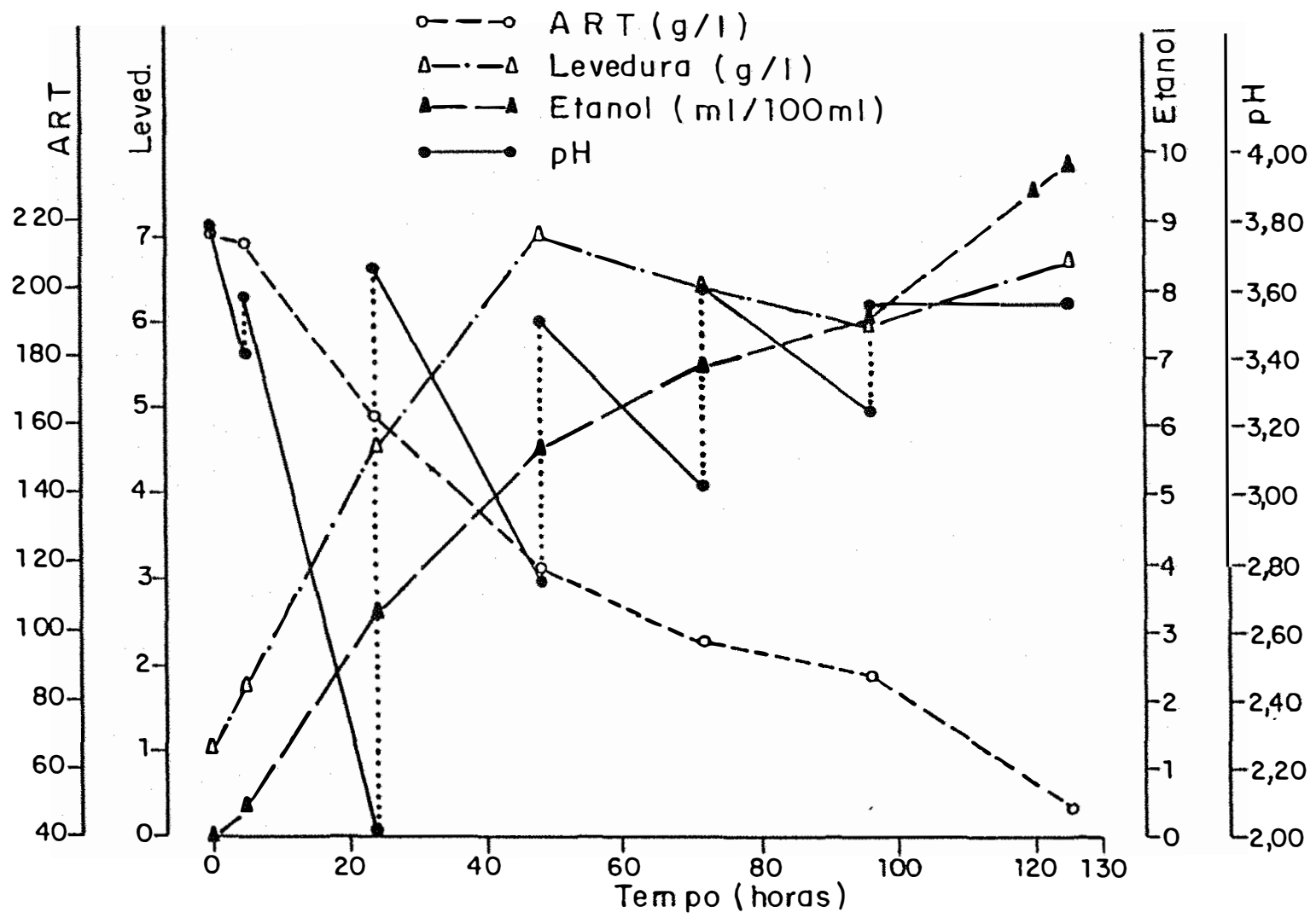

Figura 20-Acúcares redutores totais, massa celular, etanol e $\mathrm{pH}$ para a 4a fermentaçāo do experimento em batelada alimentada.

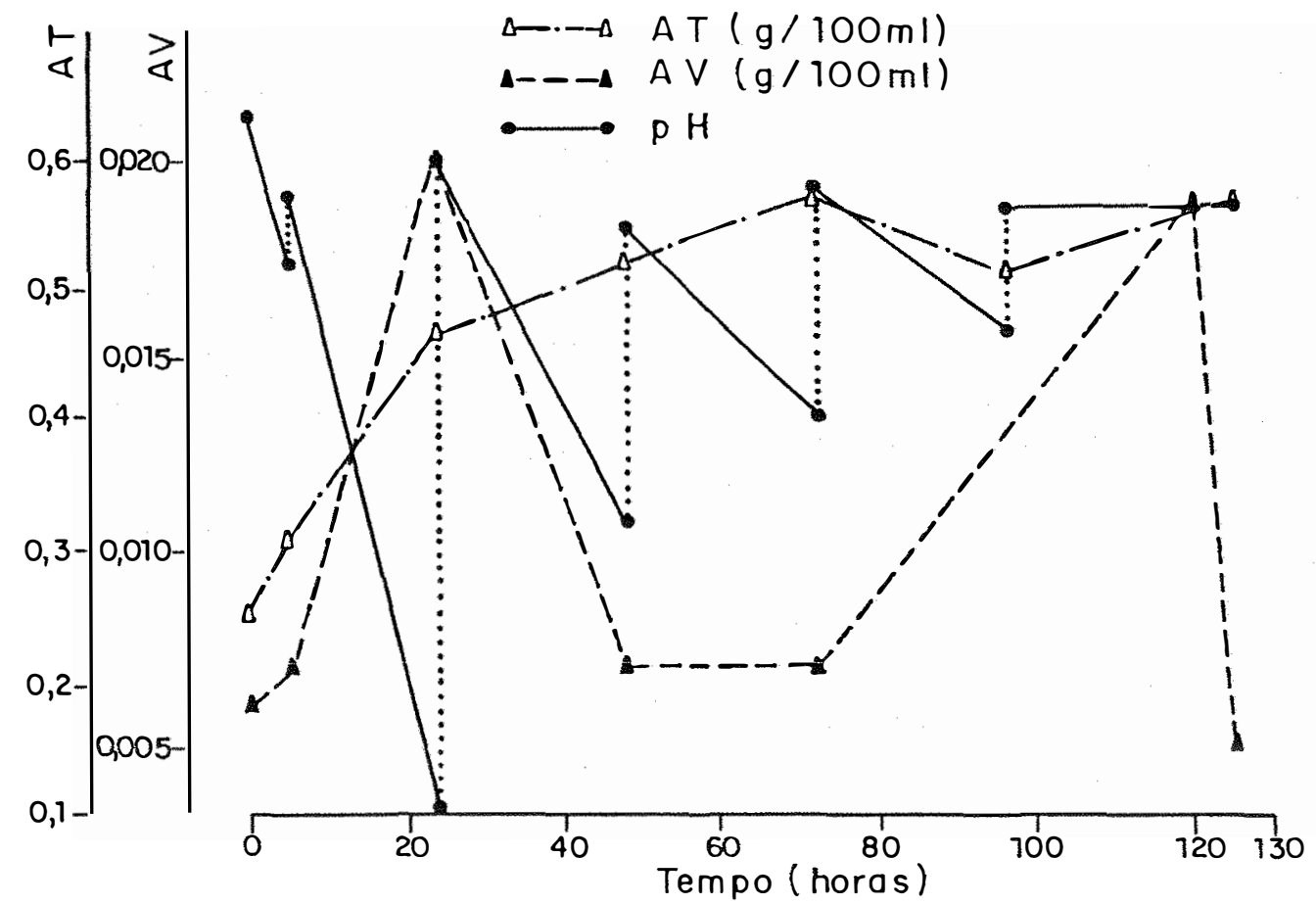

$I$
0
$-3,80$
$-3,60$
$-3,40$
$-3,20$
$-3,00$
$-2,80$
$-2,60$
$-2,40$
$-2,20$
$-2,00$

Figura 21-Ácidos totais (AT), ácidos voláteis (AV) e pH para a 4a fermentaçāo do experimento em batelada alimentada. 
Condições experimentais ( $5^{2}$ fermentação)

Concentração do mosto em ART $=213,95 \mathrm{~g} / 1$

Volume total do mosto adicionado $=10,0$ litros

Inóculo, massa seca $=0,97 \mathrm{~g} / 1$

Levedura $=$ linhagem isolada do fermento prensado

Mel de laranjeira $=708,5 \mathrm{~g} /$ alimentação $($ total $=2,83 \mathrm{Kg})$

Agitação $=100 \mathrm{rpm}$

Ajuste de $\mathrm{pH}$ do mosto $=1,5 \mathrm{~g} / 1$ de ácido cítrico $+1,24 \mathrm{~g} / 1$ de fosfato de potássio

Correção de pH durante a fermentação $=\mathrm{K}_{2} \mathrm{HPO}_{4}$

Correção mineral: $1,587 \mathrm{~g} / \mathrm{l}$ de sulfato de amônio

$0,185 \mathrm{~g} / 1$ de cloreto de magnésio 
Tabela 27. Resultados da 5 a fermentação do experimento em batelada alimentada, com controle de $\mathrm{pH}$ com $\mathrm{K}_{2} \mathrm{HPO}_{4}$, pela linhagem de levedura isolada do fermento prensado.

\begin{tabular}{|c|c|c|c|c|c|c|c|c|c|c|}
\hline $\begin{array}{l}\text { AMOSTRA } \\
\text { (no) }\end{array}$ & $\begin{array}{c}\text { TEMPO } \\
\text { (h) }\end{array}$ & $\begin{array}{c}\text { TEMPERAT. } \\
\left({ }^{\circ} \mathrm{C}\right)\end{array}$ & $\mathrm{pH}^{2}$ & $\begin{array}{c}\mathrm{K}_{2} \mathrm{HPO}_{4} \\
(\mathrm{~g})\end{array}$ & $\mathrm{pH}^{3}$ & $\begin{array}{c}\text { LEVEDURA } \\
\text { m.s. } \\
(\mathrm{g} / \mathrm{l})\end{array}$ & $\begin{array}{c}\text { ÁLCOOL } \\
(\mathrm{ml} / 100 \mathrm{ml})\end{array}$ & $\begin{array}{l}\text { A.R.T } \\
(g / l)\end{array}$ & $\begin{array}{c}\text { ACIDEZ } \\
\text { TOTAL } \\
(g / 100 \mathrm{ml})\end{array}$ & $\begin{array}{l}\text { ACIDEZ } \\
\text { VOLÁTIL } \\
\text { (g/100ml) }\end{array}$ \\
\hline 1 & 0 & 24,5 & 3,79 & - & - & 0,97 & - & 213,95 & 0,24 & 0,005 \\
\hline 2 & 5,0 & 25,0 & 3,46 & 1,5 & 3,67 & 1,56 & 0,36 & 208,23 & 0,32 & 0,006 \\
\hline 3 & 24,0 & 26,0 & 2,06 & 12,5 & 3,64 & 4,31 & 3,18 & 163,23 & 0,52 & 0,020 \\
\hline 4 & 48,0 & 24,0 & 2,75 & 12,5 & 3,52 & 6,97 & 5,65 & 118,90 & 0,51 & 0,007 \\
\hline 5 & 72,0 & 23,5 & 3,07 & 15,0 & 3,60 & 6,27 & 6,72 & 97,16 & 0,60 & 0,007 \\
\hline 6 & 96,0 & 23,0 & 3,25 & 10,0 & 3,54 & 5,80 & 7,59 & 86,43 & 0,53 & 0,030 \\
\hline 7 & 120,0 & 25,0 & - & - & - & - & 9,22 & - & $\cdot \quad-$ & \\
\hline 8 & 126,0 & 25,0 & 3,60 & - & - & 6,50 & 9,96 & 48,10 & 0,59 & 0,007 \\
\hline $\begin{array}{l}\text { AMOSTRA } \\
\text { (no) }\end{array}$ & \multicolumn{2}{|c|}{$\begin{array}{l}\text { TEMPO1 } \\
\text { (h) }\end{array}$} & $\begin{array}{l}\text { VOLUME }^{4} \\
\text { TOTAL } \\
\text { (ml) }\end{array}$ & & \multicolumn{2}{|c|}{$\begin{array}{l}\text { LEVEDURA } \\
\text { m.s. } \\
\text { (g) }\end{array}$} & ALCOOL & $\begin{array}{l}\text { A.R.T. } \\
\text { (g) }\end{array}$ & $\begin{array}{c}\text { ACIDEZ } \\
\text { TOTAL } \\
\text { (g) }\end{array}$ & $\begin{array}{c}\text { ACIDEZ } \\
\text { VOLÁTIL } \\
\text { (g) }\end{array}$ \\
\hline 1 & 0 & & 2.500 & & 2,42 & & - & 534,87 & 6,00 & 0,12 \\
\hline 2 & 5,0 & & 2.500 & & 3,90 & & 0,28 & 520,57 & 8,00 & 0,15 \\
\hline 3 & $24, C$ & & 2.500 & & 10,77 & & 2,50 & 408,07 & 13,00 & 0,50 \\
\hline 4 & 48, & & 5.000 & & 34,85 & & 4,46 & 594,50 & 25,50 & 0,35 \\
\hline 5 & 72, & & 7.500 & & 47,02 & & 5,31 & 728,70 & 45,00 & 0,52 \\
\hline 6 & 96, & & 10.000 & & 58,00 & & 6,00 & 864,30 & 53,00 & 3,00 \\
\hline 7 & 120 & & 10.000 & & - & & 7,27 & - & $-\cdot$ & \\
\hline 8 & 126 & & 10.000 & & 65,00 & & 7,87 & 481,00 & 59,00 & 0,70 \\
\hline
\end{tabular}

Tempo de fermentação.

2-Antes da correção.

3 - Após adição de $\mathrm{K}_{2} \mathrm{HPO}_{4}$.

4. A adição do mosto em batelada alimentada foi realizada em fraçōes de $2.500 \mathrm{ml}$, a cada 24 horas, sendo a alíquota retidada imediatamente antes de cada adiçăo. 
Condições experimentais ( $6^{\mathrm{a}}$ fermentação)

Concentração do mosto em ART $=212,52 \mathrm{~g} / 1$

Volume total do mosto adicionado $=10,0$ litros

Inóculo, massa seca $=1,06 \mathrm{~g} / 1$

Levedura $=$ linhagem isolada do fermento prensado

Mel de laranjeira $=708,5 \mathrm{~g} /$ alimentação $($ total $=2,83 \mathrm{Kg}$ )

Agitação $=100 \mathrm{rpm}$

Ajuste de $\mathrm{pH}$ do mosto $=1,5 \mathrm{~g} / 1$ de ácido cítrico $+1,24 \mathrm{~g} / \mathrm{l}$ de fosfato de potássio

Correção de $\mathrm{pH}$ durante a fermentação $=\mathrm{K}_{2} \mathrm{HPO}_{4}$

Correção mineral: 1,587 g/l de sulfato de amônio

$0,185 \mathrm{~g} / 1$ de cloreto de magnésio 
Tabela 28. Resultados da 6 a fermentação do experimento em batelada alimentada, com controle de pH com $\mathrm{K}_{2} \mathrm{HPO}_{4}$, pela linhagem de levedura isolada do fermento prensado.

\begin{tabular}{|c|c|c|c|c|c|c|c|c|c|c|}
\hline $\begin{array}{l}\text { AMOSTRA } \\
\text { (n의) }\end{array}$ & $\begin{array}{c}\text { TEMPO } \\
\text { (h) }\end{array}$ & $\begin{array}{l}\text { TEMPERAT. } \\
\left({ }^{\circ} \mathrm{C}\right)\end{array}$ & $\mathrm{pH}^{2}$ & $\begin{array}{c}\mathrm{K}_{2} \mathrm{HPO}_{4} \\
\text { (g) }\end{array}$ & $\mathrm{pH}^{3}$ & $\begin{array}{c}\text { LEVEDURA } \\
\text { m.s. } \\
\text { (g/l) }\end{array}$ & $\begin{array}{r}\text { ÁLCOOL } \\
(\mathrm{ml} / 100 \mathrm{ml})\end{array}$ & $\begin{array}{l}\text { A.R.T } \\
\text { (g/I) }\end{array}$ & $\begin{array}{l}\text { ACIDEZ } \\
\text { TOTAL } \\
(g / 100 \mathrm{ml})\end{array}$ & $\begin{array}{l}\text { ACIDEZ } \\
\text { VOLÁTIL } \\
(\mathrm{g} / 100 \mathrm{ml})\end{array}$ \\
\hline 1 & 0 & 24,5 & 3,82 & - & - & 1,06 & - & 212,52 & 0,24 & 0,005 \\
\hline 2 & 5,0 & 25,0 & 3,42 & 1,5 & 3,59 & 1,65 & 0,36 & 211,09 & 0,31 & 0,009 \\
\hline 3 & 24,0 & 26,0 & 2,04 & 12,5 & 3,68 & 4,46 & 3,10 & 164,38 & 0,50 & 0,021 \\
\hline 4 & 48,0 & 24,0 & 2,76 & 12,5 & 3,51 & 7,04 & 5,65 & 118,90 & 0,53 & 0,007 \\
\hline 5 & 72,0 & 23,5 & 3,06 & 15,0 & 3,60 & 6,32 & 7,04 & 95,78 & 0,65 & 0,009 \\
\hline 6 & 96,0 & 23,0 & 3,25 & 10,0 & 3,55 & 6,07 & 7,83 & 82,55 & 0,53 & 0,029 \\
\hline 7 & 120,0 & 25,0 & - & - & - & - & 9,55 & - & - & * \\
\hline 8 & 126,0 & 25,0 & 3,60 & - & - & 6,82 & 10,13 & 46,76 & 0,60 & 0,006 \\
\hline
\end{tabular}

\begin{tabular}{cccccccc}
\hline AMOSTRA & TEMPO1 & VOLUME $^{4}$ & LEVEDURA & ALCOOL & A.R.T. & ACIDEZ & ACIDEZ \\
(no) & (h) & TOTAL & m.s. & $(g / 100 \mathrm{ml})$ & $(\mathrm{g})$ & TOTAL & VOLALTIL
\end{tabular}

$(\mathrm{ml})$

(g)

(g)

(g)

\begin{tabular}{lccccccc}
\hline 1 & 0 & 2.500 & 2,65 & - & 531,30 & 6,00 & 0,12 \\
2 & 5,0 & 2.500 & 4,12 & 0,28 & 527,72 & 7,75 & 0,22 \\
3 & 24,0 & 2.500 & 11,15 & 2,45 & 410,95 & 12,50 & 0,52 \\
4 & 48,0 & 5.000 & 35,20 & 4,46 & 594,50 & 26,50 & 0,35 \\
5 & 72,0 & 7.500 & 47,40 & 5,55 & 718,35 & 48,75 & 0,67 \\
6 & 96,0 & 10.000 & 60,70 & 6,18 & 825,50 & 53,00 & 2,90 \\
7 & 120,0 & 10.000 & - & 7,54 & - & - & - \\
8 & 126,0 & 10.000 & 68,20 & 7,99 & 467,60 & 60,00 & 0,60 \\
\hline
\end{tabular}

- Tempo de fermentação.

* Antes da correção.

3 - Após adição de $\mathrm{K}_{2} \mathrm{HPO}_{4}$.

4 - A adição do mosto em batelada alimentada foi realizada em fraçōes de $2.500 \mathrm{ml}$, a cada 24 horas, sendo a aliquota retidada imediatamente antes de cada adiçăo. 
Condições experimentais ( $7^{\mathbf{a}}$ fermentação)

Concentração do mosto em ART $=225,42 \mathrm{~g} / 1$

Volume total do mosto adicionado $=10,0$ litros

Inóculo, massa seca $=0,79 \mathrm{~g} / 1$

Levedura $=$ linhagem isolada do fermento prensado

Mel de laranjeira $=708,5 \mathrm{~g} /$ alimentação $($ total $=2,83 \mathrm{Kg}$ )

Agitação $=100$ rpm

Ajuste de $\mathrm{pH}$ do mosto $=1,5 \mathrm{~g} / 1$ de ácido cítrico $+1.2 \mathrm{~g} / 1$ de fosfato de potássio

Correção de pH durante a fermentação $=\mathrm{K}_{2} \mathrm{HPO}_{4}$

Correção mineral: $1,587 \mathrm{~g} / 1$ de sulfato de amônio

$0,185 \mathrm{~g} / 1$ de cloreto de magnésio 
Tabela 29. Resultados da $7^{\mathfrak{a}}$ fermentação do experimento em batelada alimentada, com controle de $\mathrm{pH}$ com $\mathrm{K}_{2} \mathrm{HPO}_{4}$, pela linhagem de levedura isolada do fermento prensado.

\begin{tabular}{|c|c|c|c|c|c|c|c|c|c|c|}
\hline $\begin{array}{l}\text { AMOSTRA } \\
\text { (nㅇ) }\end{array}$ & $\begin{array}{l}\text { TEMPO } \\
\text { (h) }\end{array}$ & $\begin{array}{c}\text { TEMPERAT. } \\
\left({ }^{\circ} \mathrm{C}\right)\end{array}$ & $\mathrm{pH}^{2}$ & $\begin{array}{c}\mathrm{K}_{2} \mathrm{HPO}_{4} \\
\text { (g) }\end{array}$ & $\mathrm{pH}^{3}$ & $\begin{array}{c}\text { LEVEDURA } \\
\text { m.s. } \\
(\mathrm{g} / \mathrm{l})\end{array}$ & $\begin{array}{c}\text { ÁLCOOL } \\
(\mathrm{ml} / 100 \mathrm{ml})\end{array}$ & $\begin{array}{c}\text { A.R.T } \\
(g / l)\end{array}$ & $\begin{array}{l}\text { ACIDEZ } \\
\text { TOTAL } \\
\text { (g/100ml) }\end{array}$ & $\begin{array}{l}\text { ACIDEZ } \\
\text { VOLÁTIL } \\
\text { (g/100ml) }\end{array}$ \\
\hline 1 & 0 & 22,0 & 3,83 & - & - & 0,79 & - & 225,42 & 0,24 & 0,005 \\
\hline 2 & 5,0 & 25,0 & 3,44 & 2,5 & 3,97 & 1,19 & 0,29 & 216,31 & 0,27 & 0,007 \\
\hline 3 & 24,0 & 24,5 & 2,45 & 10,5 & 3,77 & 4,77 & 3,60 & 157,29 & 0,40 & 0,014 \\
\hline 4 & 48,0 & 24,5 & 2,76 & 14,5 & 3,67 & 6,59 & 6,18 & 107,39 & 0,53 & 0,012 \\
\hline 5 & 72,0 & 25,0 & 3,22 & 15,0 & 3,84 & 6,70 & 7,59 & 84,40 & 0,53 & 0,009 \\
\hline 6 & 96,0 & 25,0 & 3,24 & 12,0 & 3,59 & 5,77 & 8,08 & 71,62 & 0,55 & 0,009 \\
\hline 7 & 120,0 & - & - & - & - & $\cdot$ & 10,38 & - & $=$ & \\
\hline 8 & 121,0 & 25,0 & 3,71 & - & - & 6,44 & 10,55 & 38,88 & 0,59 & 0,007 \\
\hline
\end{tabular}

\begin{tabular}{|c|c|c|c|c|c|c|c|c|}
\hline $\begin{array}{l}\text { AMOSTRA } \\
\text { (no) }\end{array}$ & $\begin{array}{l}\text { TEMPO1 } \\
\text { (h) }\end{array}$ & $\begin{array}{l}\text { VOLUME } \\
\text { TOTAL } \\
\text { (mi) }\end{array}$ & DENSIDADE & $\begin{array}{l}\text { LEVEDURA } \\
\text { m.s. } \\
\text { (g) }\end{array}$ & $\begin{array}{l}\text { ALCOOL } \\
\text { (g/100ml) }\end{array}$ & $\begin{array}{l}\text { A.R.T. } \\
\text { (g) }\end{array}$ & $\begin{array}{l}\text { ACIDEZ } \\
\text { TOTAL } \\
\text { (g) }\end{array}$ & $\begin{array}{c}\text { ACIDEZ } \\
\text { VOLÁTIL } \\
\text { (g) }\end{array}$ \\
\hline 1 & 0 & 2.500 & 1,123 & 1,97 & - & 563,55 & 6,0 & 0,12 \\
\hline 2 & 5,0 & 2.500 & 1,087 & 2,97 & 0,23 & 540,77 & 6,7 & 0,17 \\
\hline 3 & 24,0 & 2.500 & 1,064 & 11,92 & 2,84 & 393,22 & 10,0 & 0,35 \\
\hline 4 & 48,0 & 5.000 & 1,050 & 32,95 & 4,88 & 536,95 & 26,5 & 0,60 \\
\hline 5 & 72,0 & 7.500 & 1,040 & 50,25 & 6,00 & 633,00 & 39,7 & 0,67 \\
\hline 6 & 96,0 & 10.000 & 1,033 & 57.70 & 6,38 & 716,20 & 55,0 & 0,90 \\
\hline 7 & 120,0 & 10.000 & - & - & 8,20 & - & - & - \\
\hline 8 & 121,0 & 10.000 & 1,019 & 64,40 & 8,33 & 388,80 & 59,0 & 0,70 \\
\hline
\end{tabular}

- Tempo de fermentação.

2. Antes da correção.

3 - Após adiçăo de $\mathrm{K}_{2} \mathrm{HPO}_{4}$.

- A adição do mosto em batelada alimentada foi realizada em frações de $2.500 \mathrm{ml}$, a cada 24 horas, sendo a aliquota retidada imediatamente antes de cada adição. 
Condições experimentais ( $8^{2}$ fermentação)

Concentração do mosto em ART $=218,69 \mathrm{~g} / 1$

Volume total de mosto adicionado $=10,0$ litros

Inóculo, massa seca $=0,76 \mathrm{~g} / 1$

Levedura $=$ linhagem isolada do fermento prensado

Mel de laranjeira $=708,5 \mathrm{~g} /$ alimentação $($ total $=2,83 \mathrm{Kg}$ )

Agitação $=100 \mathrm{rpm}$

Ajuste de $\mathrm{pH}$ do mosto $=1,5 \mathrm{~g} / 1$ de ácido círico $+1,2 \mathrm{~g} / 1$ de fosfato de potássio Correção mineral: $1,587 \mathrm{~g} / 1$ de sulfato de amônio

$0,185 \mathrm{~g} / 1$ de cloreto de magnésio 
Tabela 30. Resultados da $8^{\text {a }}$ fermentação do experimento em batelada alimentada, com controle de $\mathrm{pH}$ com $\mathrm{K}_{2} \mathrm{HPO}_{4}$, pela linhagem de levedura isolada do fermento prensado.

\begin{tabular}{|c|c|c|c|c|c|c|c|c|c|c|}
\hline $\begin{array}{l}\text { AMOSTRA } \\
\text { (nO) }\end{array}$ & $\begin{array}{c}\text { TEMPO }{ }^{1} \\
\text { (h) }\end{array}$ & $\begin{array}{c}\text { TEMPERAT. } \\
\left({ }^{\circ} \mathrm{C}\right)\end{array}$ & $\mathrm{pH}^{2}$ & $\begin{array}{c}\mathrm{K}_{2} \mathrm{HPO}_{4} \\
\text { (g) }\end{array}$ & $\mathrm{pH}^{3}$ & $\begin{array}{l}\text { LEVEDURA } \\
\text { m.s. } \\
(\mathrm{g} / \mathrm{l})\end{array}$ & $\begin{array}{l}\text { ÁLCOOL } \\
(\mathrm{ml} / 100 \mathrm{ml})\end{array}$ & $\begin{array}{l}\text { A.R.T } \\
\text { (g/l) }\end{array}$ & $\begin{array}{c}\text { ACIDEZ } \\
\text { TOTAL } \\
(g / 100 \mathrm{ml})\end{array}$ & $\begin{array}{l}\text { ACIDEZ } \\
\text { VOLÁTIL } \\
\text { (g/100ml) }\end{array}$ \\
\hline 1 & 0 & 22,0 & 3,81 & - & - & 0,76 & - & 218,69 & 0,26 & 0,005 \\
\hline 2 & 5,0 & 25,0 & 3,47 & 2,5 & 3,98 & 1,10 & 0,29 & 215,67 & 0,27 & 0,007 \\
\hline 3 & 24,0 & 24,5 & 2,44 & 10,5 & 3,73 & 4,60 & 3,39 & 160,92 & 0,44 & 0,017 \\
\hline 4 & 48,0 & 24,5 & 2,72 & 14,5 & 3,59 & 5,98 & 5,65 & 114,14 & 0,48 & 0,007 \\
\hline 5 & 72,0 & 25,0 & 3,17 & 15,0 & 3,70 & 6,19 & 6,88 & 96,39 & 0,52 & 0,007 \\
\hline 6 & 96,0 & 25,0 & 3,22 & 12,0 & 3,56 & 5,49 & 7,91 & 81,21 & 0,57 & 0,009 \\
\hline 7 & 122,0 & 25,0 & 3,71 & - & - & 6,13 & 10,05 & 46,48 & 0,60 & 0,007 \\
\hline
\end{tabular}

\begin{tabular}{|c|c|c|c|c|c|c|c|c|}
\hline $\begin{array}{l}\text { AMOSTRA } \\
\text { (n) }\end{array}$ & $\begin{array}{l}\text { TEMPO1 } \\
\text { (h) }\end{array}$ & $\begin{array}{l}\text { VOLUME }^{4} \\
\text { TOTAL } \\
(\mathrm{ml})\end{array}$ & DENSIDADE & $\begin{array}{l}\text { LEVEDURA } \\
\text { m.s. } \\
\text { (g) }\end{array}$ & $\begin{array}{l}\text { ÁLCOOL } \\
(\mathrm{g} / 100 \mathrm{ml})\end{array}$ & $\begin{array}{l}\text { A.R.T. } \\
\text { (g) }\end{array}$ & $\begin{array}{l}\text { ACIDEZ } \\
\text { TOTAL } \\
\text { (g) }\end{array}$ & $\begin{array}{c}\text { ACIDEZ } \\
\text { VOLÁTIL } \\
\text { (g) }\end{array}$ \\
\hline 1 & 0 & 2.500 & 1,123 & 1,90 & - & 546,72 & 6,50 & 0,12 \\
\hline 2 & 5,0 & 2.500 & 1,088 & 2,75 & 0,23 & 539,17 & 6,70 & 0,17 \\
\hline 3 & 24,0 & 2.500 & 1,067 & 11,50 & 2,67 & 402,30 & 11,00 & 0,42 \\
\hline 4 & 48,0 & 5.000 & 1,054 & 29,90 & 4,46 & 570,70 & 24,00 & 0,35 \\
\hline 5 & 72,0 & 7.500 & 1,045 & 46,42 & 5,13 & 722,92 & 39,00 & 0,52 \\
\hline 6 & 96,0 & 10.000 & 1,038 & 54,90 & 6,25 & 812,10 & 57,00 & 0,90 \\
\hline 7 & 122,0 & 10.000 & 1,022 & 61,30 & 7,93 & 464,80 & 60,00 & 0,70 \\
\hline
\end{tabular}

- Tempo de fermentação.

- Antes da correção.

3 - Após adição de $\mathrm{K}_{2} \mathrm{HPO}_{4}$.

4 - A adição do mosto em batelada alimentada foi realizada em frações de $2.500 \mathrm{ml}$, a cada 24 horas, sendo a aliquota retidada imediatamente antes de cada adição. 
Condições experimentais $\left(9^{2}\right.$ fermentação)

Concentração do mosto em ART $=217,47 \mathrm{~g} / 1$

Volume total do mosto adicionado $=10,0$ litros

Inóculo, massa seca $=0,83 \mathrm{~g} / 1$

Levedura $=$ linhagem isolada do fermento prensado

Mel de laranjeira $=708,5 \mathrm{~g} /$ alimentação $($ total $=2,83 \mathrm{Kg}$ )

Agitação $=100 \mathrm{rpm}$

Ajuste de $\mathrm{pH}$ do mosto $=1,5 \mathrm{~g} / \mathrm{l}$ de ácido cítrico $+1,2 \mathrm{~g} / \mathrm{l}$ de fosfato de potássio

Correção de $\mathrm{pH}$ durante a fermentação $=\mathrm{K}^{2} \mathrm{HPO}_{4}$

Correção mineral: $1,587 \mathrm{~g} / 1$ de sulfato de amônio

$0,185 \mathrm{~g} / 1$ de cloreto de potássio 
Tabela 31. Resultados da $9^{a}$ fermentação do experimento em batelada alimentada, com controle de pH com $\mathrm{K}_{2} \mathrm{HPO}_{4}$, pela linhagem de levedura isolada do fermento prensado.

\begin{tabular}{|c|c|c|c|c|c|c|c|c|c|c|}
\hline $\begin{array}{l}\text { AMOSTRA } \\
\text { (no) }\end{array}$ & $\begin{array}{c}\text { TEMPO } \\
\text { (h) }\end{array}$ & $\begin{array}{l}\text { TEMPERAT. } \\
\text { (०C) }\end{array}$ & $\mathrm{pH}^{2}$ & $\begin{array}{c}\mathrm{K}_{2} \mathrm{HPO}_{4} \\
(\mathrm{~g})\end{array}$ & $\mathrm{pH}^{3}$ & $\begin{array}{l}\text { LEVEDURA } \\
\text { m.s. } \\
(g n)\end{array}$ & $\begin{array}{c}\text { ÁLCOOL } \\
(\mathrm{ml} / 100 \mathrm{ml})\end{array}$ & $\begin{array}{l}\text { A.R.T } \\
(g n)\end{array}$ & $\begin{array}{c}\text { ACIDEZ } \\
\text { TOTAL } \\
\text { (g/100ml) }\end{array}$ & $\begin{array}{c}\text { ACIDEZ } \\
\text { VOLÁTIL } \\
(g / 100 \mathrm{ml})\end{array}$ \\
\hline 1 & 0 & 22,0 & 3,83 & * & $=$ & 0,83 & - & 217,47 & 0,27 & 0,005 \\
\hline 2 & 5,0 & 25,0 & 3,47 & 2,5 & 3,98 & 1,19 & 0,29 & 210,91 & 0,28 & 0,007 \\
\hline 3 & 24,0 & 24,5 & 2,44 & 10,5 & 3,76 & 4,74 & 3,32 & 155,11 & 0,44 & 0,019 \\
\hline 4 & 48,0 & 24,5 & 2,80 & 14,5 & 3,72 & 6,31 & 6,57 & 102,26 & 0,48 & 0,021 \\
\hline 5 & 72,0 & 25,0 & 3,30 & 14,0 & 3,78 & 7,01 & 8,56 & 69,33 & 0,52 & 0,007 \\
\hline 6 & 96,0 & 25,0 & 3,31 & 12,0 & 3,69 & 6,05 & 8,16 & 53,95 & 0,56 & 0,007 \\
\hline 7 & 120,0 & - & - & - & - & $=$ & 11,39 & - & - & - \\
\hline 8 & 121,0 & 25,0 & 3,81 & - & - & 6,56 & 11,48 & 23,17 & 0,60 & 0,005 \\
\hline
\end{tabular}

\begin{tabular}{|c|c|c|c|c|c|c|c|c|}
\hline $\begin{array}{l}\text { AMOSTRA } \\
\text { (no) }\end{array}$ & $\begin{array}{c}\text { TEMPO' } \\
\text { (h) }\end{array}$ & $\begin{array}{l}\text { VOLUME } \\
\text { TOTAL } \\
\text { (ml) }\end{array}$ & DENSIDADE & $\begin{array}{l}\text { LEVEDURA } \\
\text { m.s. } \\
\text { (g) }\end{array}$ & $\begin{array}{r}\dot{A} L C O O L \\
(g / 100 \mathrm{ml})\end{array}$ & $\begin{array}{l}\text { A.R.T. } \\
\text { (g) }\end{array}$ & $\begin{array}{l}\text { ACIDEZ } \\
\text { TOTAL } \\
\text { (g) }\end{array}$ & $\begin{array}{r}\text { ACIDEZ } \\
\text { VOLÁTIL } \\
\text { (g) }\end{array}$ \\
\hline 1 & 0 & 2.500 & 1,122 & 2,07 & - & 543,67 & 6,75 & 0,12 \\
\hline 2 & 5,0 & 2.500 & 1,088 & 2,97 & 0,23 & 527,27 & 7,00 & 0,17 \\
\hline 3 & 24,0 & 2.500 & 1,067 & 11,85 & 2,61 & 387,77 & 11,00 & 0,47 \\
\hline 4 & 48,0 & 5.000 & 1,051 & 31,55 & 5,18 & 511,30 & 24,00 & 1,00 \\
\hline 5 & 72,0 & 7.500 & 1,033 & 52,57 & 6,76 & 519,97 & 39,00 & 0,52 \\
\hline 6 & 96,0 & 10.000 & 1,023 & 60,50 & 6,44 & 539,50 & 56,00 & 0,70 \\
\hline 7 & 120,0 & 10.000 & - & - & 9,00 & - & - & - \\
\hline 8 & 121,0 & 10.000 & 1,011 & 65,60 & 9,06 & 231,70 & 60,00 & 0,50 \\
\hline
\end{tabular}

- Tempo de fermentação.

* Antes da correção.

3 - Após adiçãode $\mathrm{K}_{2} \mathrm{HPO}_{4}$

4 - A adição do mosto em batelada alimentada foi realizada em fraçōes de $2.500 \mathrm{ml}$, cada 24 horas, sendo a aliquota retidada imediatamente antes de cada adição. 


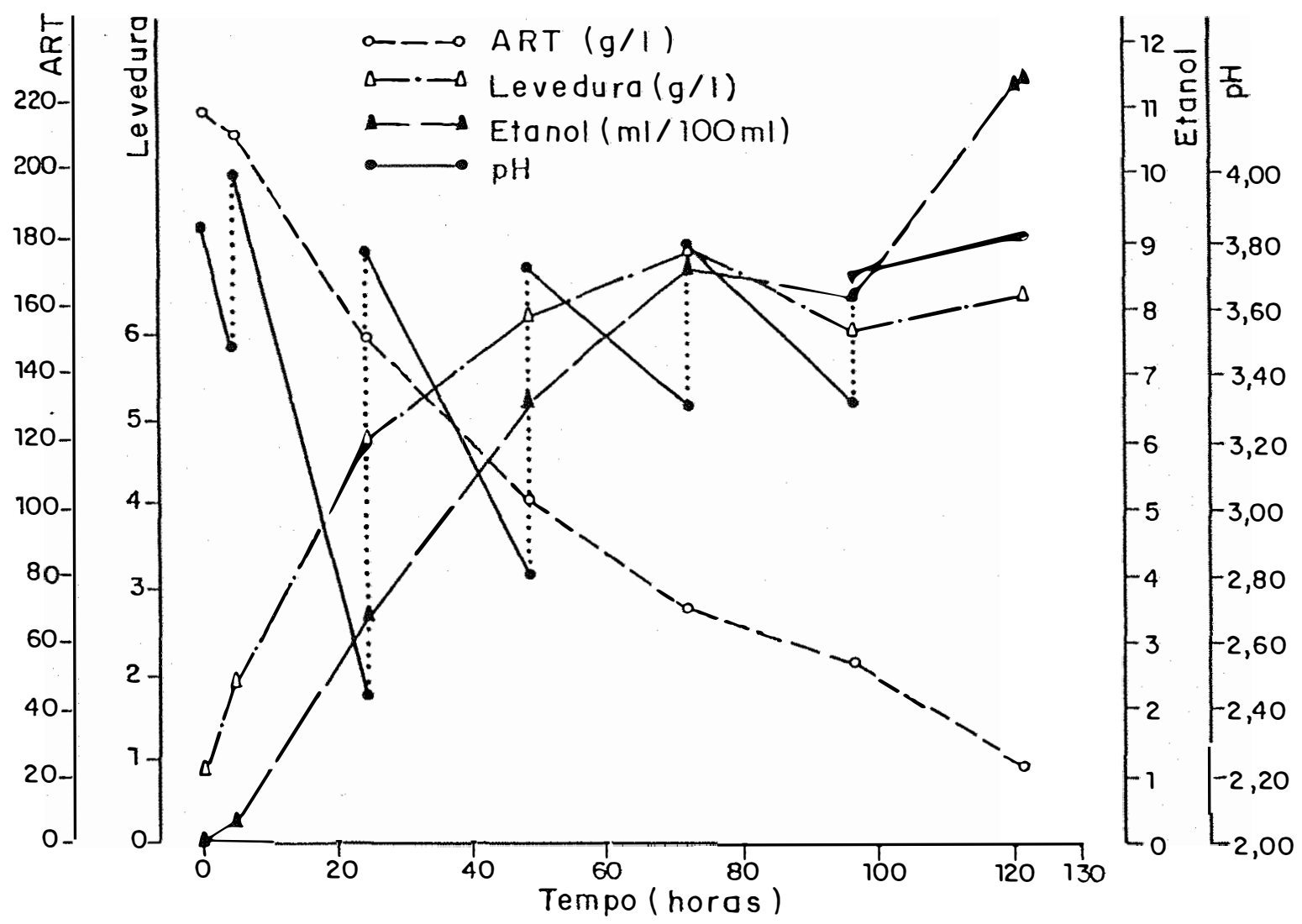

Figura 22 - Açúcares redutores totais, massa celular, etanol e pH para a 99 fermentaçāo do experimento em batelada alimentada.

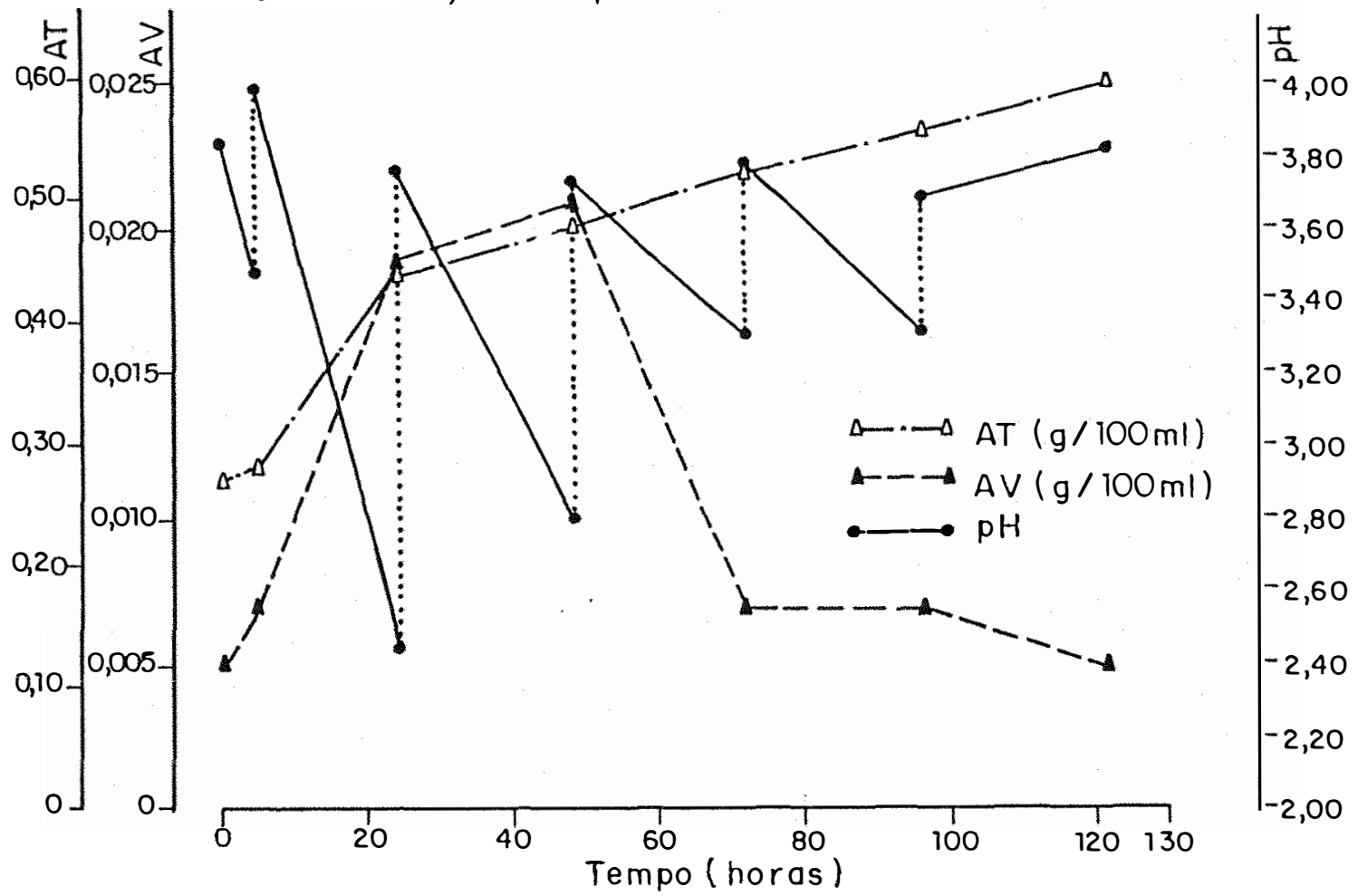

Figuro 23-Ácidos totais (AT), ácidos volateis (AV) e pH para a 99 fer mentaçāo do experimento em batelada alimentada. 
Esta última série de ensaios em batelada alimentada com agitação e correção de pH com sal de fosfato de potássio foi conduzida identicamnte ao processo descrito em 4.4.1.

Adotou-se toda a metodologia até agora desenvolvida nos ensaios anteriores, desde o preparo do inóculo até a condução do ensaio que foi realizada através de seis fermentações consecutivas.

A diferença em comparação com os tratamentos anteriores, além da correção de $\mathrm{pH}$ com sal de fosfato bipotássico, foi o mosto com concentração de açúcares redutores em torno de $215-220 \mathrm{~g} / 1$ de modo a permitir a paralisação da fermentação com um teor de açúcar residual da ordem de 40,0 a 50,0 g/l, concentração esta considerada como suficiente para dar um sabor suave, agradável, ao menos ao julgamento de nossos auxiliares de degustação. A correção de pH com fosfato foi satisfatória e tecnicamente parece indiferente a utilização, restando um estudo econômico para a aplicação prática.

Não foi levado em conta a dificuldade séria que se constitui a filtração do produto, para impedir a continuação da fermentação por eventuais células remanescentes.

A filtração utilizada após centrifugação contou apenas com CELITE 503 como elemento auxiliar e o ajuste dessa técnica não pode ser melhor acompanhada nessa série de ensaios, embora a indicação de uso já constasse da Patente $\mathbf{n}^{0} 3.598 .607$ (MORSE \& STEINKRAUS, 1971). 
Como já referido, um estudo mais aprofundado do produto final seria desejável para concluir se não há vantagens de estabilidade em se obter um produto tipo seco, devidamente filtrado e posteriormente adicionado de mel até o padrão escolhido, além de corrigido para acidez dentro dos padrões requeridos e pasteurizado como consta na própria patente citada.

Não foi possível qualquer estudo sobre estabilidade, envelhecimento ou acompanhamento da qualidade do vinho pós produção, ainda que essencial e necessário para uma conclusão do presente tipo de trabalho. 


\section{CONCLUSÕES}

1. O mel é um substrato muito rico em açúcares, porém, limitado em sais minerais para que se possa utilizá-lo unicamente no cultivo ou fermentação com leveduras.

2. Na produção de hidromel, com teor alcóolico em torno de 10 a $12 \%$, há necessidade de suplementação mineral do mosto, principalmente com os elementos $\mathrm{N}$ e $\mathrm{P}$.

3. Dado o baixo poder tampão do meio de mel, durante a fermentação há necessidade de adição de neutralizantes para o excesso de ácidos orgânicos formados.

4. A não neutralização da acidez formada, afeta a viabilidade das leveduras no decorrer do tempo de fermentação, levando a paralisação da fermentação por redução da população.

5. A agitação de 100 rpm no sistema estudado colabora para a manutenção da suspensão do microrganismo e para a correção de acidez produzida, proporcionando sensível ganho de produtividade, da ordem de $50 \%$ em relação ao processo estático. 
6. A concentração de inóculo considerada satisfatória para ambos os processos, batelada e batelada alimentada, foi em torno de 0,20-0,30 g/1 de matéria seca.

7. A produtividade volumétrica encontrada em torno de $0,80 \mathrm{ml} \cdot \mathrm{l}^{-1} \cdot \mathrm{h}^{-1}$, foi considerada satisfatória na condução do processo fermentativo a $24-26^{\circ} \mathrm{C}$.

8. As substâncias empregadas como neutralizantes ou tamponantes utilizadas foram hidróxido de potássio e fosfato dipotássico que produziram idêntico efeito sobre a viabilidade do microrganismo e a fermentação.

9. Correção de acidez, limpidez e flavor podem ser necessários na obtenção de um melhor produto final e, para tal, seria desejável a obtenção de um fermentado tipo seco seguido de separação de microrganismo, tratamento e pasteurização.

10. Não foi possível a distinção entre os produtos das fermentações conduzidas pelas linhagens de Saccharomyces cerevisiae (IZ-888) e da isolada do fermento prensado comercial.

11. Estudos complementares com análise sensorial são desejáveis na otimização do processo e total desenvolvimento do produto. 


\section{REFERÊNCIAS BIBLIOGRÁFICAS}

ADAM, B. Mead. Bee World, Cardiff, 34(8): 149-56, Aug. 1953.

ADAMS, S.L. \& NIESEN, G.V. Honey beverage and process for making it. Patente Industrial (Estados Unidos), $\mathrm{n}^{\mathrm{o}} 3,100.705 .13$ Aug. 1963.

ALMEIDA, J.R. de. Tecnologia do álcool. Piracicaba, CALQ, 1958. 137 p.

ALMEIDA, S.B.G. Fermentação alcoólica: ensaios em batelada convencional e em batelada alimentada. Rio de Janeiro, 1980. 108p. (Mestrado-Escola Química/Universidade Federal do Rio de Janeiro).

AMARAL, E. \& ALVES, S.B. Insetos úteis. Piracicaba, Livroceres, 1979. 192 p.

AMERINE, M.A. Composition of wines. I. Organic constituents. Advances in Food Research, New York, 5: 353-510, 1954. 
AMERINE, M.A. \& CRUESS, W.V. The technology of wine making. New York, AVI Publ., 1960. 709 p.

AMERINE, M.A. \& OUGH, C.S. Wine and must analysis. New York, John Wiley, 1974. $121 \mathrm{p}$.

AQUARONE, E. Generalidade sobre bebidas alcoolicas. In: AQUARONE, E.; LIMA V. de A.; BORZANI, W. Alimentos e bebidas produzidas por fermentação. São Paulo, Edgar Bucher, 1983. cap.1. p.1-13. (Biotecnologia, $5)$.

AQUARONE, E.; SATO, S.; BORZANI, W. Non-constant fed-batch ethanol fermentation of molasses (preliminary tests). Arquivos de Biologia e Tecnologia, Curitiba, 29 (2): 327-35, 1986.

BACILA, M. Curso de fisiologia de microrganismo. Curitiba, Instituto de Bioquímica/UFPr, 1960. 209 p.

BAILEY, J.E. \& OLLIS, D.F. Biochemical engineering fundamentals. 2 ed., New York, McGraw-Hill, 1986. 984p. 
BERGERET, G. \& DE CASTRO, J.A. Hidromiel. Revista de la Associacion de Ingenieros Agronomos, Montevideo, 15: 67-70, 1943.

BERNARD, M. Controle organoléptico. In: SCRIBAN, R. Coord. Biotecnologia, São Paulo, Editora Monole Ltda., 1985. cap. 4. p. 371-83.

BERTHOLD JR., R. A new concept in mead making. American Bee Journal, Hamilton, 128(12): 820-4, Dec. 1988.

BORZANI, W. Kinetics of ethanol production during the reactor feeding phase in constant fedbacth fermentation of molasses. Biotechnology and Bioengineering, New York, 29: 844-9, 1987.

BRASIL. Ministério da Agricultura. Secretaria Nacional de Defesa Agropecuária. Secretaria de Inspeção de Produto Vegetal. Complementação de padrões de identidade e qualidade para fermentados alcóolicos e acético. s.1., s.d. 93 p.

CONWAY, E.J. \& BRADY, T.G. Biological production of acid and alkali. Biochemical Journal, Cambridge, 47(2): 360-9, 1950.

CONWAY, E.J. \& DOWNEY, M. An outer metabolic region of the yeast cell. Biochemical Journal, Cambridge, 47(2): 347-55, 1950. 
COTTRELL, T.H.E. \& Mc LELLAN, M.R. The effect of fermentation temperature on chemical and sensory characteristics of wines from seven white grape cultivars grown in New York State. American journal of Enology and Viticulture, Davis, 37(3): 190-4, 1986.

CRANE, E. O livro do mel. São Paulo, Nobel, 1983. 226p.

DAUDT, C.E. \& GARCIA, N.G. Minerais em videiras, mostos e vinhos brasileiros I. Minerais em vinhos. Ciência e Tecnologia de Alimentos, Campinas, 7(1): $72-$ $81,1987$.

DAUDT, C.E.; GARCIA, N.G.; RIZZON, L.A. Minerais em videiras, mostos e vinhos II. Minerais em mostos, sua utilização durante a fermentação alcóolica e presença em vinhos. Ciência e Tecnologia de Alimentos, Campinas, 7(2): 189-204, 1987.

DENNIS, C.B. B.B.K.A. offers advice on making mead. British Bee Journal, Geddington, 80: 216-8, 233-4, 248-50, 1952.

GOMORI, G. A modification of the colorimetric phosphorus determination of use with the photoeletric colorimeter. Journal of Laboratory and Clinical Medicine, St. Louis, 27: 955-60, 1942. 
GUYMON, J.F.; INGRAHAM, J.L.; CROWELL, E.A. The formation of n-propyl alcohol by Saccharomyces cerevisiae. Archives of Biochemistry and Biophysics, Duluth, 95: 163-8, 1961.

HARRISON, J.S. Yeast production. Progress in Industrial Microbiology, Edinburgh, 10: 129-77, 1971.

HARRISON, J.S. \& GRAHAM, J.C.J. Yeasts in destillery practice. In: ROSE, A.H. ed. The yeasts. London, Academic Press, 1970, v.3. cap.6. p.283-348.

HASHIZUME, T. Maturação e envelhecimento de vinho. Boletim do Instituto de Tecnologia de Alimentos, Campinas, 51: 1-13, 1977.

HASHIZUME, T. Fundamentos de tecnologia do vinho. In: AQUARONE, E.; LIMA, U. de A.; BORZANI, W. Alimentos e bebidas produzidos por fermentação. São Paulo, Edgard Blücher, 1983, p.14-43. (Biotecnologia, 5).

HERRAIZ, T.; ALVAREZ, P.J.M.; REGLERO, G.; HERRAIZ, M.; CABEZUDO, M.D. Differences between wines fermented with and without sulphur dioxide using various selected yeasts. Journal of the Science Food and Agriculture, Essex, 49: 248-58, 1989. 
HORII, J. Condução de processos fermentativos. In: SEMINÁRIO SOBRE A TECNOLOGIA E ECONOMIA DO ÁlCOOL, 1. Piracicaba, 1980. Anais. Piracicaba, Coordenadoria da Indústria e Comércio, 1980. p147.

JARCZYC, A. \& WZOREK, W. Fruit and honey wines. In: ROSE, A.H. ed. Alcoholic beverages. London, Academic Press, 1977. cap. 5. p. 387-421. (Economic Microbiology, 1).

KOSHIMIZU, L.H.; CRUZ, M.R. de M.; GOMEZ, E.I.V.; NETTO, C.L.B.; GONÇALVES, A.C.R.; BORZANI, W. Avaliação da concentração de leveduras suspensas em um meio aquoso pela medida do volume ocupado pelas células. Saccharum, Piracicaba, 5(18): 14-6, jan., 1982.

KUNKEE, R.E. \& AMERINE, M.A. Yeasts in wine-making. In: ROSE, A.H. \& HARRISOM J.S., ed. The yeasts. New York, Academic Press, 1970, p. 5-71.

LESS, P.M. Influência da substância nitrogenada em um fermentado de hidromel sobre as características de seu destilado alcóolico. Brasil Açucareiro, Rio de Janeiro, 22(3): 209-12, set. 1943. 
LIMA, U. de A. Aguardentes. In: AQUARONE, E.; LIMA, U. de A.; BORZANI, W. Alimentos e bebidas produzidos por fermentação. São Paulo, Edgard Blücher, 1983, cap. 4, p. 79-102. (Biotecnologia, 5).

MARGALITH, P. \& SCHWARTZ, Y. Flavor and microorganisms. Advances in Applied Microbiology, New York, 12: 35-88, Mar., 1970.

MARTINELLI FILHO, A. Tecnologia de vinhos e vinagres de frutas; agroindústria de baixo investimento. São Paulo, Secretaria da Indústria, Comércio, Ciência e Tecnologia, 1982. 130p.

MAUGENET, J. L'hidromel. Annales de L'abeille, Paris, 7(3): 165-79, 1964.

MORAES, J.M. de. Aditivos e coadjuvantes de tecnologia de fabricação para bebidas e vinagres. Boletim da Sociedade Brasileira de Ciência e Tecnologia de Alimentos. Campinas, 22(3/4): 173-182, 1988.

MORSE, R.A. Honey wine and vinegar. Gleanings in Bee Culture, Medina, 81(8): 461, 491, 508, Aug. 1953a.

MORSE, R.A. Honey wine and vinegar. Gleanings in Bee Culture, Medina, 81(9): 536-9, Sept. 1953b. 
MORSE, R.A. Honey wine: and how to make it. Gleanings in Bee Culture, Medina, 92: 338-43, 1964.

MORSE, R.A. Honey wine (mead) making. Gleanings in Bee Culture, Medina, 98: $38-41,58,1970$.

MORSE, R.A. An annotated bibliography on honey wines (mead). New York, 1972. 21p. (Bibl. Bee Research Association, 3).

MORSE, R.A. \& STEINKRAUS, K.H. Method of making wine from honey. Patente Industrial (Estados Unidos), no 3,598,607. 10 Aug. 1971.

MORSE, R.A. \& STEINKAUS, K.H. Wines from the fermentation of honey. In: CRANE, E. Honey. London, Heinemann, 1975. cap. 16, p. 392-407.

NAGODAWITHANA, T.W.; CASTELLANO, C.; STEINKRAUS, K.H. Effect of dissolved oxigen, temperature, initial cell count, and sugar concentration on the viability of Saccharomyces cerevisiae in "rapid fermentation". Applied Environmental Microbiology, Washington, 28 (3): 383-91, 1974. 
NEISH, A.C. Determination of reducing sugars. In: NATIONAL RESEARCH COUNCIL OF CANADA. Analytical methods for bacterial fermentation. 2. ed. Saskatoon, 1952. p.34. (Report, 46-8-3).

OUGHT, C.S. \& AMERINE, M.A. Studies with controlled fermentation X. Effect of fermentation temperature on some volatile compounds in wine. American Journal of Enology and Viticulture, Davis, 18: 157-64, 1967.

OUGHT, C.S. \& CROWELL, E.A. Use of sulfur dioxide in winemaking. Journal of Food Science, Champaign, 52(2): 386-8, 393, 1987.

PAMPULHA, M.E.F.S. \& LOUREIRO-DIAS, M.C. Combined effect of acetic acid, $\mathrm{pH}$ and ethanol on intracellular $\mathrm{pH}$ of fermenting yeast. Applied Microbiology and Biotechnology, Berlin, 31: 547-50, 1989.

PATO, O. O vinho. Lisboa, Clássica, 1963. 421 p.

PEYNAUD, E. El gusto del vino, Madrid, Mundi-Prensa, 1987. 239p.

PETROV, V. Mineral constituents of some australian honeys as determinated by atomic absorption spectrophotometry. Journal of Agricultural Research, Cardiff, 9(2): 95-101, 1970. 
PIERCE, J.S. Analysis committee measurement of yeast viability. Journal of Institute of Brewing, London, 76(5): 442-3, 1970.

PONS, M.N.; PICHON, D.; AUTHIER, M. Monitoring of alcoholic fermentations of fruit juices via a gas membrane sensor. Journal of Fermentation and Bioengineering, Amsterdam, 68(4): 282-5, 1989.

QURESHI, N. \& TAMHANE, D.V. Production of mead by immobilized whole cells of Saccharomyces cerevisiae. Applied Microbiology and Biotechnology, New York, 21(5): 280-1, 1985.

RIBÉREAU-GAYON, J. \& PEYNAUD, E. Traite d'oenologie. Paris, Librarie Polytech. ch. Béranger, 1961. 1065p.

ROSINI, G. Wine-making by cell-recycle-batch fermentation process. Applied Microbiology and Biotechnology, Berlin, 24: 140-3. 1986.

ROSSI, J. Indagini microbiologiche sul tecc etiopico. Annali di Microbiologia edi Enzimologia, Milan, 9: 150-60, 1959. 
SAKAI, L.A.; GONÇALVES, R.H.; HORII, J. Matéria-seca em leveduras. Comparação entre secagem em estufa e em forno microondas. In: CONGRESSO DE INICIAÇÃO CIENTÍfICA DA ESALQ, 5. Piracicaba, 1990. Anais. Piracicaba, ESALQ, 1990, p.74

SCHREIER, P. Flavor composition of wines - a review. CRC Critical Reviews in Food Science and Nutrition, Boca Raton, 12(1): 59-11 1, 1979.

SCHUETTE, H.A. \& HUENINK, D.J. Mineral constituints of honey. II. Phosphorous, calcium, magnesium. Food Research, Champaign, 2: 529-38, 1937.

SERZEDELLO, A. Fermentação alcoólica do mel de abelhas. In: Semana de fermentação alcoólica, 1, Piracicaba, 1960. Anais. Piracicaba, Instituto Zimotécnico, 1960. v. 2. p. 366-74.

SIGLER, K; KOTYK, A.; KNOTKOVA, A.; OPEKAROVA, M. Process involved in the reation of buffering capacity and in subtrate induced proton extrusion and in the yeast Saccharomyces cerevisiae. Biochemical Biophysical Acta, Amsterdan, 643(3): 583-92, 1981. 
STEINKRAUS, K.H. \& MORSE, R.A. Factors influencing the fermentation of honey in mead production. Journal of Apicultural Research, Cardiff, 5 (1): 17-26, 1966.

STEINKRAUS, K.H. \& MORSE, R.A. Chemical analysis of honey wines. Journal of Apicultural Research, Cardiff, 12(3): 191-5, 1973.

STEINKRAUS, K.H.; MORSE, R.A.; MINH, H.V.; MENDOZA, B.V. \& LAIGO, F.M. Chemical analysis of honey: a brief summary 1900-1971. Bee World, Cardiff, 52(3): 122-7, 1971.

STOUTHAMER, A.H. \& VAN VERSEVELD, H.W. Stoichiome of microbial growth. In: MOO-YOUNG, M. ed. Comprehensive biotechnology; the principles, applications and regulations of biotechnology in industry, agriculture and medicine. Oxford, Pergamon Press, 1985. v.1. cap. 12. p. 215-38.

STUPIELLO, J.P. \& HORII, J. Condução da fermentação alcóolica. Saccharum, São Paulo, 4(17): 43-6, 1981.

SUOMALAINEN, $\mathrm{H}$. Yeast and its effect on the flavour of alcoholic beverages. Journal of the Institute of Brewing, London, 77: 164-76, 1971. 
TELlO, M.P. O que comiam os nossos antepassados. Gazeta do Agricultor, Lourenço Marques, 25(292): 269-8, nov./dez. 1973.

THORNE, R.S.W.; HELM, E.; SVENDSEN, K. Control of sulphury impurities in beer aroma. Journal of the Institute of Brewing, London, 77: 148-53, 1971.

TRIBOLI, E.P.R. Métodos analíticos para o acompanhamento da fermentação alcóolica. São Caetano do Sul, Instituto Mauá de Tecnologia, 1987. 40p.

VALSECHI, O. Aguardente de cana-de-açúcar. Piracicaba, Livroceres, 1960.118p.

VAN TOL FILHO, P.L. Criação racional de abelhas; "criação e lavoura", São Paulo, Melhoramentos, 1964. $164 \mathrm{p}$.

VIANA, L. de S. \& MOUCHREY, E. O valor social do mel como alimento. Informe Agropecuário, Belo Horizonte, 7 (75): 51-6, mar. 1981.

VIDAL, R. Comportamento de coleta de "mel de cana" por abelhas do Gênero Apis e estudo do aproveitamento desse alimento. São Paulo, 1983. 80 p. (Mestrado Instituto de Biociências/Universidade Estadual Paulista "Júlio de Mesquita Filho"). 
VILELA, G.G.; BACILA, M.; TASTALDI, H. Técnicas e experimentos de bioquímica. Rio de Janeiro, Guanabara Koogan, 1972. 552p.

WEBB, A.D. \& INGRAHAM, J.L. Fusel oil. Advances in Applied Microbiology, New York, 5: 317-53, 1963.

WHITE JR, J.W. Composition of honey. In: CRANE, E., ed. Honey: a comprehensive survey. London, Heinemann, 1975. cap. 5, p.157-206.

WHITE JR, J.W. Honey. In: ATKINS, E.L. ed. The hive and the honey bee. Hamilton, Dadant and Sons, 1975. cap. 17, p.491-530.

WYNDHAM, D.J. Honey wine. Gleanings in Bee Culture, Medina, 93: 426-8, 1965. 